\title{
SOLARIZAÇÃO DO SOLO EM AMBIENTE PROTEGIDO E SUA INTEGRAÇÃO COM CONTROLE BIOLÓGICO OU QUÍMICO NA
}

VIABILIDADE DE Pythium aphanidermatum E Rhizoctonia solani

\section{FLÁVIA RODRIGUES ALVES PATRICIO \\ Engenheiro Agrônomo}

Orientador: Prof. Dr. HIROSHI KIMATI

Tese apresentada à Escola Superior de Agricultura "Luiz de Queiroz", Universidade de São Paulo, para obtenção do título de Doutor em Agronomia, Área de Concentração: Fitopatologia.

\author{
$P \mid R A C I C A B A$ \\ Estado de São Paulo - Brasil \\ Fevereiro - 2000
}




\section{Dados Internacionais de Catalogação na Publicaçāo (CIP)}

DIVISĀO DE BIBLIOTECA E DOCUMENTAÇĀO - Campus "Luiz de Oueiroz"/USP

Patricio, Flávia Rodrigues Alves

Solarização do solo em ambiente protegido e sua integração com controle biológico ou quimico na viabilidade de Pythium aphanidermatum e Rhizoctonia solani/ Flávia Rodrigues Alves Patricio. - - Piracicaba, 2000.

89 p.

Tese (doutorado) - Escola Superior de Agricultura Luiz de Queiroz, 2000.

Bibliografia.

1. Controle biológico 2. Controle químico 3. Esterilização do solo 4. Fungo fitopatogênico 5. Microbiologia do solo 6. Solarização do solo I. Titulo 
Ao meu esposo Heitor e ao meu filho Vitor, pela compreensão,

DEDICO 


\section{AGRADECIMENTOS}

Ao Prof. Hiroshi Kimati pela excelente orientação e amizade.

À funcionária Zélia Brasilino, do Instituto Biológico, pela valiosa participação e auxilio na condução e avaliação dos experimentos.

Ao funcionário Gerson A. Almeida, do Departamento de Produção Vegetal da ESALQ-USP, pelo inestimável auxilio na instalação dos esperimentos e cuidadoso registro das temperaturas do solo.

Aos funcionários do Departamento de Produção Vegetal Gaudêncio Stenico e José Nivaldo dos Santos pelo grande auxílio na instalação e condução dos experimentos.

À estagiária do Instituto Biológico, Vanessa F. Ferreira de Souza, pelo valoroso auxílio na condução dos experimentos.

Ao Pesquisador Científico Paulo Roberto Mariotto, do Intituto Biológico, pela colaboração e precisão na avaliação dos experimentos.

Ao Pesquisador Científico Benedito C. Barros, do Instituto Biológico pelo auxílio na condução dos experimentos e revisão do texto.

Aos funcionários Francisco $B$. Del Vechio, Alcides V. Machado e Jésus Barbosa, José A. Picin e Edson pela colaboração na instalação e condução dos experimentos.

Ao Prof. João Tessarioli e aos responsáveis pela área experimental do Dep. de Produção Vegetal, Aparecido D. Serrano e Erreinaldo D. Bortolazzo, pela generosa concessão da casa de vegetação e viabilização da realização dos experimentos.

À Dra. Evelyn Fernandes Koch e à empresa AGROFLORA S.A. pelo pronto fornecimento das sementes de pepino utilizadas nos experimentos.

À Pesquisadora Dra Raquel Ghini da Empresa Brasileira de Pesquisa Agropecuária - EMBRAPA - CNPMA, pelas valiosas sugestões, grande generosidade e auxilio na condução dos experimentos.

Ao Prof. Dr. Ademir Petenatti, do Instituto de Matemática, Estatística e Computação Científica - IMECC da UNICAMP pela realização das análises estatísticas dos experimentos e auxílio na interpretação dos dados. 
Ao Pesquisador Científico Heitor Cantarella, do Instituto Agronômico, pelo incentivo, revisão do texto e elaboração do Summary.

À Pesquisadora Científica Vanda M. Angeli Malavolta, do Instituto Biológico, pela revisão do texto.

Aos professores, colegas e funcionários do Departamento de Entomologia, Fitopatologia e Zoologia Agrícola pela agradável convivência, auxílio na condução dos experimentos e pela oportunidade de realização do Curso de Pós-Graduação.

Aos colegas da CATI, Leila, Roberto, Vilma, Maria Inês, Nélio, Coutinho, Jorge, Rodrigo e Angelini, pelo apoio e incentivo.

Ao Prof. José Otávio M. Menten pelo apoio e incentivo.

Ao Instituto Biológico pela liberação para realização do curso de pósgraduação e auxilio para condução deste trabalho. 


\section{SUMÁRIO}

Página

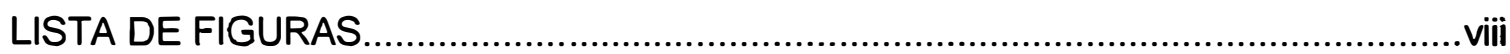

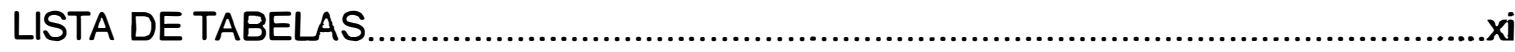

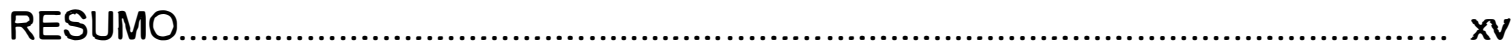

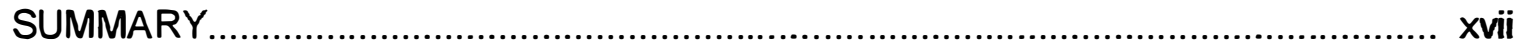

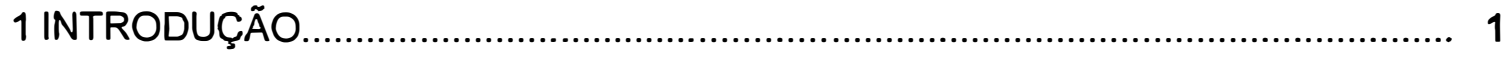

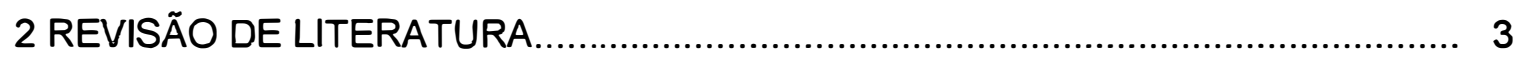

2.1 Pythium aphanidermatum e Rhizoctonia solani ........................................... 3

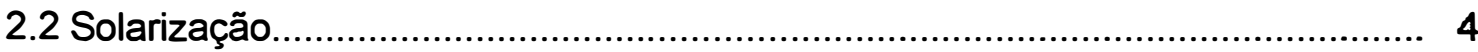

2.2.1. Solarização dentro de casas de vegetação e dupla solarização............... 5

2.2.2. Solarização para o controle de Pythium aphanidermatume

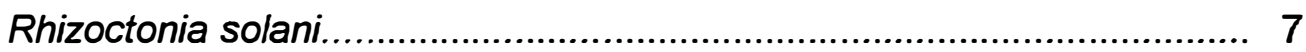

2.3. Integração da solarização com controle biológico........................................... 8

2.3.1 Trichoderma spp. no controle biológico................................................ 9

2.3.2 Aplicação de Trichoderma spp. e solarização.......................................... 12

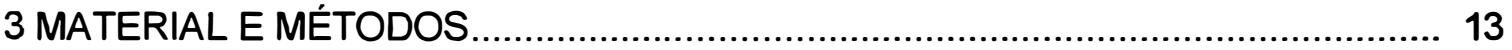

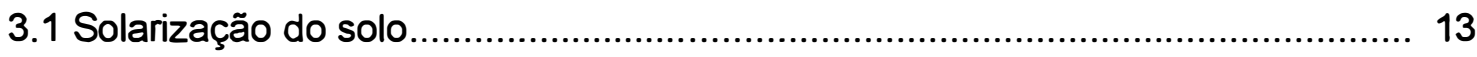

3.1.1 Preparo das amostras com Pythium aphanidermatum e Rhizoctonia

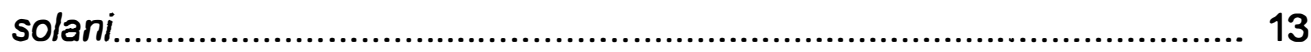

3.1.2 Experimentos de solarização............................................................. 14

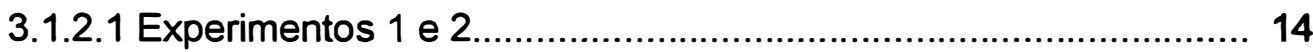

3.1.2.2 Experimentos 3, 4 e 5....................................................... 15

3.1.3 Avaliação da viabilidade dos patógenos............................................... 17

3.2 Integração da solarização com controle biológico e químico............................. 18

3.2.1 Obtenção dos isolados de Trichoderma spp. antagônicos a Pythium aphanidermatum e Rhizoctonia solani.................................................. 18

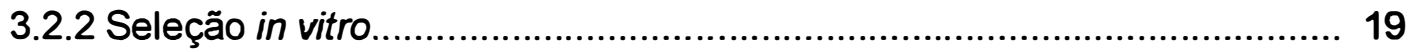

3.2.2.1 Crescimento de Pythium aphanidermatum e Rhizoctonia solani em cultivo pareado com isolados de Trichoderma spp. 
3.2.2.2 Produção de substâncias tóxicas difusiveis por isolados de Trichoderma spp................................................................... 20

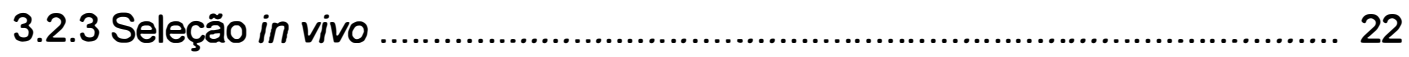

3.2.3.1 Antagonismo de isolados de Trichoderma spp. a Pythium aphanidermatum.

3.2.3.2 Antagonismo de isolados de Trichoderma spp. a Rhizoctonia solani.

3.2.4 Integração da solarização com a incorporação de Trichoderma spp. e com o controle químico

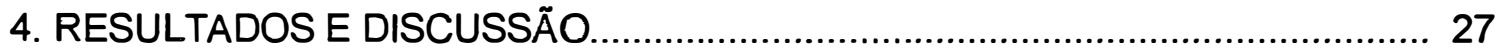

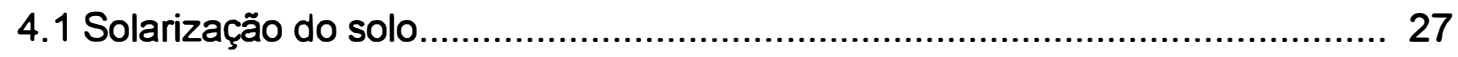

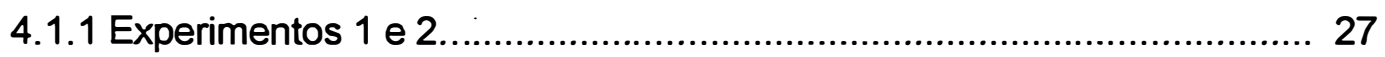

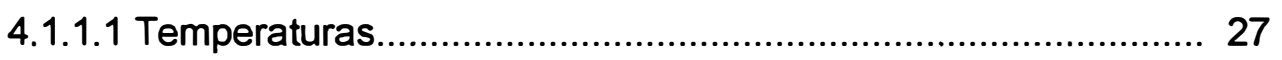

4.1.1.2 Viabilidade de Pythium aphanidermatum ............................... 30

4.1.1.3 Viabilidade de Rhizoctonia solani............................................ 35

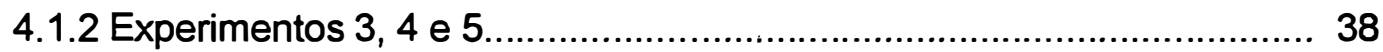

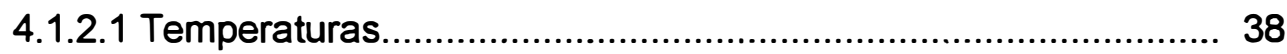

4.1.2.2 Viabilidade de Pythium aphanidermatum................................ 39

4.1.2.3 Viabilidade de Rhizoctonia solani.............................................. 46

4.1.3 Discussão dos experimentos de solarização........................................ 51

4.1.3.1 Temperaturas................................................................. 51

4.1.3.2 Viabilidade de Pythium aphanidermatum ................................. 53

4.1.3.3 Viabilidade de Rhizoctonia solani........................................... 56

4.2. Avaliação da integração da solarização com controle biológico ou químico.... 59

4.2.1 Obtenção dos isolados de Trichoderma spp. antagônicos a Pythium aphanidermatum e Rhizoctonia solani.............................................. 59

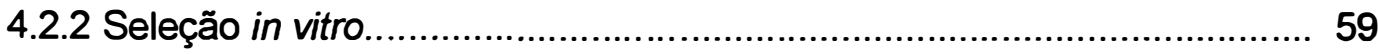

4.2.2.1 Avaliação de antagonismo de isolados de Trichoderma spp. a Pythium aphanidermatum e Rhizoctonia solani................................. 59 
4.2.2.2 Produção de substâncias tóxicas difusiveis por isolados de Trichoderma spp.......................................................... 62

4.2.3 Seleção in vivo....................................................................... 64

4.2.3.1 Antagonismo de isolados de Trichoderma spp. a Pythium aphanidermatum. 64

4.2.3.2 Antagonismo de isolados de Trichoderma spp. a Rhizoctonia solani 67

4.2.4 Avaliação da integração da solarização com a incorporação de Trichoderma spp. e com o controle químico. 71 5 CONCLUSÕES. 78 


\section{LISTA DE FIGURAS}

Página

Figura 1. Temperaturas obtidas na casa de vegetação e na área externa, a 10 e a $20 \mathrm{~cm}$ de profundidade, às $15: 00$ e às 8:00 horas no experimento 1. As temperaturas foram avaliadas, de segunda a sexta-feira, no período de 05 a 23 de janeiro de 1998. Piracicaba, SP.

Figura 2. Temperaturas obtidas dentro da casa de vegetação e na área extema a 10 e a $20 \mathrm{~cm}$ de profundidade, às $15: 00$ e às 8:00 horas no experimento 2 . As temperaturas foram avaliadas, de segunda a sexta-feira, no período 05 de fevereiro a 16 de março de 1998. Piracicaba, SP.

Figura 3. Médias da viabilidade de Pythium aphanidermatum, avaliada pela porcentagem de tombamento, dos tratamentos solarizados e não solarizados, dentro da casa de vegetação e na área externa, dos experimentos 1 e 2. Piracicaba, SP.

Figura 4. Médias da viabilidade de Pythium aphanidermatum no experimento 1 avaliada pela porcentagem de tombamento, com os tratamentos solarizados e não solarizados, a 10 e a $20 \mathrm{~cm}$ de profundidade, dentro da casa de vegetação e na área externa. Piracicaba, SP

Figura 5. Médias da viabilidade de Pythium aphanidermatum nos experimentos 1 e 2 avaliada pela porcentagem de tombamento, com os tratamentos solarizados e não solarizados dentro da casa de vegetação e na área externa, aos 20, 30 e 40 dias após o seu início. Piracicaba, SP 
Figura 6. Médias da viabilidade de Rhizoctonia solani, avaliada pela porcentagem de sementes com micélio viável do patógeno, dos tratamentos solarizados e não solarizados, aos 20, 30 e 40 dias após o início dos experimentos 1 efetuado no período de 18/12/97 a 26/01/98 e 2, realizado no período de 05/02 a 16/03/98, dentro da casa de vegetação e na área externa. Piracicaba, SP.

Figura 7. Médias da viabilidade de Rhizoctonia solani, avaliada pela porcentagem de sementes com micélio viável do patógeno, dos tratamentos solarizados e não solarizados dos experimentos 1 , efetuado no período de 18/12/97 a 26/01/98 e 2, realizado no período de 05/02 a 16/03/98, dentro da casa de vegetação e na área externa. Piracicaba, SP

Figura 8. Médias da viabilidade de Pythium aphanidermatum, avaliada pela porcentagem de tombamento, dos tratamentos solarizados e não solarizados, a 10 e a $20 \mathrm{~cm}$ de profundidade, aos 15 e aos 45 dias após o início do experimento 3, realizado no período de 24/11/98 a 07/01/99, dentro da casa de vegetação e na área externa. Piracicaba, SP

Figura 9. Médias da viabilidade de Pythium aphanidermatum, avaliada pela porcentagem de tombamento, dos tratamentos solarizados e não solarizados, a 10 e a $20 \mathrm{~cm}$ de profundidade, observadas no experimento 5, realizado no período de 28/02 a 16/04/1999 dentro da casa de vegetação e na área externa. Piracicaba, SP.

Figura 10. Médias da viabilidade de Pythium aphanidermatum, avaliada pela porcentagem de tombamento de pós-emergência, dos tratamentos solarizados e não solarizados, dos experimentos 3 e 5 realizados, respectivamente, nos períodos de 24/11/98 a 07/01/99 e 28/02 a 16/04/99, dentro da casa de vegetação e na área externa. Piracicaba, SP 
Figura 11. Médias da viabilidade de Rhizoctonia solani, avaliada pela porcentagem de sementes com micélio viável do patógeno, dos tratamentos solarizados e não solarizados, dentro da casa de vegetação e na área externa, em avaliações aos 15, 30 e 45 dias após o início dos experimentos 4 e 5 realizados, respectivamente, nos períodos de 29/01 a 11/03/99 e 28/02 a 16/04/99. Piracicaba, SP.

Figura 12. Médias da viabilidade de Rhizoctonia solani, avaliada pela porcentagem de sementes com micélio viável do patógeno, dos tratamentos solarizados e não solarizados, aos 15, 30 e 45 dias após o inicio dos experimentos 4 e 5 , realizados, respectivamente nos periodos de 29/01 a 11/03/99 e 28/02 a 16/04/99, dentro da casa de vegetação na área externa. Piracicaba, SP.

Figura 13. Efeito da adição de isolados de Trichoderma na dose de $10 \mathrm{~g}$ de sementes colonizadas/litro de solo, sobre a porcentagem de plântulas de rabanete sobreviventes ao tombamento de pré e pós emergência, 4 a 9 dias após o plantio, em experimento realizado em casa de vegetação. Campinas, SP., Abril - Maio, 1999.

Figura 14. Plântulas de pepino sobreviventes ao tombamento de pósemergência provocado por Pythium aphanidermatum, em dois experimentos realizados na casa de vegetação e na área externa, após solarização, efetuada no período de 26 de fevereiro a 25 de março de 1999 seguida de incorporação ao solo do isolado 26 de Trichoderma ou aplicação de metalaxyl + mancozeb. Campinas, SP - Maio, 1999

Figura 15. Plântulas de rabanete sobreviventes ao tombamento de pré e pósemergência provocado por Rhizoctonia solani, em dois experimentos realizados em casa de vegetação e em área externa, após solarização, efetuada durante o periodo de 26 de fevereiro a 25 de março de 1999, e posterior incorporação do isolado 17 de Trichoderma sp. ou após o tratamento com pencycuron. Campinas, SP. - Abril - Maio, 1999 


\section{LISTA DE TABELAS}

Página

Tabela 1. Datas de instalação, coleta de amostras com propágulos dos patógenos Pythium aphanidermatum e Rhizoctonia solani, e períodos de avaliação da temperatura, a 10 e a $20 \mathrm{~cm}$ de profundidade, às 8:00 e às 15:00 horas, dos experimentos 1 e $2 \ldots \ldots$.

Tabela 2. Datas de instalação, coleta de amostras com propágulos dos patógenos Pythium aphanidermatum e Rhizoctonia solani, e períodos de avaliação da temperatura, a 10 e a $20 \mathrm{~cm}$ de profundidade, às 15:00 horas, dos experimentos $3,4,5$ e 6

Tabela 3. Isolados testados e data de realização dos experimentos de pareamento de isolados de Trichoderma spp. com Pythium aphanidermatum e Rhizoctonia solani.

Tabela 4. Isolados testados e data de realização dos experimentos de difusão de substâncias tóxicas a Pythium aphanidermatum e Rhizoctonia solani produzidas por isolados de Trichoderma spp. em meio BDA...

Tabela 5. Temperaturas médias e máximas do solo obtidas às 8:00 e 15:00 horas, na casa de vegetação e na área externa, a 10 e a $20 \mathrm{~cm}$ de profundidade, nos experimentos, $1^{1}$ e $2^{2}$. Piracicaba, SP.

Tabela 6. Fatores, tratamentos e médias da viabilidade de Pythium aphanidermatum, avaliada pela porcentagem de tombamento de plântulas de pepino, nos experimentos $1^{1}$ e $2^{2}$. Piracicaba, SP...........

Tabela 7. Fatores, tratamentos e médias da viabilidade de Rhizoctonia solani, avaliada pela porcentagem de sementes com micélio viável do patógeno, nos experimentos $1^{1}$ e $2^{2}$

Tabela 8. Temperaturas médias e máximas do solo obtidas às 15:00 horas na casa de vegetação e na área externa, a 10 e a $20 \mathrm{~cm}$ de profundidade, nos experimentos, $3^{1}, 4^{2}$ e $5^{3}$. Piracicaba, SP. 
Tabela 9. Médias de viabilidade de Pythium aphanidermatum, avaliada pela porcentagem de tombamento, e teste de significância (Teste F) dos períodos (15, 30 e 45 dias) avaliados e interações com os fatores ambiente, solarização e profundidade para os experimentos 3 e 5 , realizados respectivamente nos períodos de 24/11/98 a 07/01/99 e 28/02 a 16/04/1999. Piracicaba, SP.

Tabela 10. Médias da viabilidade de Pythium aphanidermatum e teste de significância (Teste $F$ ), para os fatores ambiente, solarização, profundidade e interações entre os mesmos nos períodos de 15 , 30 e 45 dias após o início dos experimentos 3 e 5 realizados, respectivamente, nos períodos de 24/11/98 a 07/01/99 e 28/02 a 16/04/99. Piracicaba, SP.

Tabela 11. Médias de viabilidade de Rhizoctonia solani, avaliada pela porcentagem de sementes com micélio viável do patógeno, e teste de significância (Teste F) dos períodos de 15, 30 e 45 dias, e interações com os fatores ambiente, solarização e profundidade para os experimentos 4 e 5 realizados, respectivamente, nos periodos de 29/01 a 11/03/99 e 28/02 a 16/04/99. Piracicaba, SP...

Tabela 12. Médias da viabilidade de Rhizoctonia solani, avaliada pela porcentagem de sementes com micélio viável do patógeno e teste de significância (Teste F) para os fatores ambiente, solarização, profundidade, e interações entre os mesmos nos períodos de 15 , 30 e 45 dias após o início dos experimentos 4 e 5 realizados, respectivamente nos periodos de 29/01 a 11/03/99 e 28/02 a 16/04/99. Piracicaba, SP

Tabela 13. Notas (classe 1 a 5) de isolados de Trichoderma spp. obtidos de solos de Campinas e Piracicaba, pareados com Pythium aphanidermatum e Rhizoctonia solani, avaliados 120 horas após o plaqueamento 
Tabela 14. Notas (classe 1 a 5) de isolados de Trichoderma spp., obtidos a partir dos experimentos de solarização, pareados com Pythium aphanidermatum e Rhizoctonia solani, avaliados 120 horas após o plaqueamento

Tabela 15. Crescimento de colônias (em mm) com 72 horas e porcentagem de inibição de Pythium aphanidermatum e Rhizoctonia solani em placas de Petri sobre BDA, colocadas após o crescimento, por 48 horas, de isolados de Trichoderma spp.

Tabela 16. Plântulas de pepino sobreviventes ao tombamento de pósemergência provocado por Pythium aphanidermatum, após o tratamento do solo com isolados de Trichoderma spp., nas doses de 5 e $10 \mathrm{~g}$ de sementes colonizadas/L de solo e com metalaxyl + mancozeb, em experimento realizado em casa de vegetação. Campinas, SP - Setembro-Outubro, 1998

Tabela 17. Plântulas de pepino sobreviventes ao tombamento de pósemergência provocado por Pythium aphanidermatum, após o tratamento do solo com isolados de Trichoderma spp. na dose de $10 \mathrm{~g}$ de sementes colonizadas/L de solo em experimento realizado em casa de vegetação. Campinas, SP - Abril, 1999.

Tabela 18. Plântulas de rabanete sobreviventes ao tombamento de pré e pósemergência provocado por Rhizoctonia solani, após o tratamento do solo com isolados de Trichoderma spp. na dose de $10 \mathrm{~g}$ de sementes colonizadas/L de solo e com pencycuron em experimento realizado em casa de vegetação. Campinas, SP Abril - Maio, 1999

Tabela 19. Temperaturas médias e máximas registradas nos solos às 15:00 horas na casa de vegetação e na área extema, a 10 e a $20 \mathrm{~cm}$ de profundidade, nos experimentos 19 e 20 , realizados no período de 26/02 a 25/03/1999. Piracicaba, SP 
Tabela 20. Fatores, tratamentos e médias de viabilidade de Pythium aphanidermatum, avaliada pela porcentagem de plântulas de pepino sobreviventes ao tombamento de pós-emergência, em dois experimentos em uma casa de vegetação e em uma área externa, após solarização, efetuada durante o período de 26 de fevereiro a 25 de março de 1999 e integração da solarização com tratamentos químico e biológico.

Tabela 21. Fatores, tratamentos e médias de viabilidade de Rhizoctonia solani, em dois experimentos, em casa de vegetação e em área externa, após solarização, efetuada durante o período de 26 de fevereiro a 25 de março de 1999, e integração da solarização com tratamentos químico e biológico. 


\title{
SOLARIZAÇÃO DO SOLO EM AMBIENTE PROTEGIDO E SUA INTEGRAÇÃO COM CONTROLE BIOLÓGICO OU QUÍMICO NA VIABILIDADE DE Pythium aphanidermatum E Rhizoctonia solani
}

\author{
Autor: FLÁVIA RODRIGUES ALVES PATRICIO \\ Orientador: PROF. DR. HIROSHI KIMATI
}

\section{RESUMO}

Com o objetivo de avaliar o controle de Pythium aphanidermatum e Rhizoctonia solani pelo emprego da solarização, em ambientes protegidos ou não, foram conduzidos experimentos no interior de uma casa de vegetação vedada $e$, em área externa à mesma, em Piracicaba, SP. A solarização consiste na colocação de um filme plástico sobre o solo umedecido, visando promover seu aquecimento, durante o periodo de maior insolação do ano.

A erradicação de Rhizoctonia solani foi obtida nos dois ambientes, por meio da solarização, por períodos variáveis, de 20 a 30 dias no interior da casa de vegetação e de 40 a 45 dias na área externa, nos meses de verão. O período necessário para promover a inativação do patógeno, considerando-se as profundidades de 10 e $20 \mathrm{~cm}$ avaliadas, foi proporcional à temperatura atingida pelos solos durante o tratamento. No ambiente protegido a solarização foi favorecida pela menor perda de calor que ocorre nesta condição, principalmente durante a noite.

Pythium aphanidermatum não foi consistentemente controlado pela solarização nos dois ambientes. Em alguns experimentos ocorreu redução na viabilidade do patógeno nas camadas mais superficiais do solo que, entretanto, foi acompanhada pelo favorecimento de sua patogenicidade na profundidade de $20 \mathrm{~cm}$.

Paralelamente foram conduzidos experimentos in vitro e in vivo visando a seleção de isolados de Trichoderma spp. antagônicos aos patógenos Pythium aphanidermatum e Rhizoctonia solani. Foram selecionados isolados de Trichoderma spp., sendo um antagônico a Pythium aphanidermatum e o outro a Rhizoctonia solani. 
O controle oferecido por estes isolados, entretanto, foi inferior ao propiciado pelo tratamento químico, efetuado com produtos muito eficientes - metalaxyl + mancozeb para o primeiro patógeno e pencycuron para $R$. solani.

O efeito da integração entre solarização e controle biológico ou químico foi avaliado utilizando-se isolados selecionados nos experimentos anteriores ou aplicandose fungicidas específicos para cada patógeno, nos solos solarizados e não solarizados obtidos dentro e fora da casa de vegetação. $A$ integração da solarização com controle biológico ou químico não resultou em efeito sinergístico no controle dos patógenos avaliados. Para Pythium aphanidermatum a incorporação do antagonista ao solo solarizado não resultou em redução na viabilidade do patógeno e o controle químico foi muito eficiente em ambas as condições do solo, solarizado e não solarizado, mesmo tendo sido aplicada metade da dose recomendada. Para Rhizoctonia solani a solarização foi tão eficiente que os tratamentos, biológico ou químico, não trouxeram benefício adicional. 


\title{
SOIL SOLARIZATION INSIDE A GREENHOUSE AND THE INTEGRATION OF SOLARIZATION AND BIOLOGICAL OR CHEMICAL CONTROL ON THE \\ VIABILITY OF Pythium aphanidermatum AND Rhizoctonia solani.
}

\author{
Author: FLÁVIA RODRIGUES ALVES PATRICIO \\ Adviser: PROF. DR. HIROSHI KIMATI
}

\section{SUMMARY}

The objective of the present work was to evaluate the control of Pythium aphanidermatum and Rhizoctonia solani, by solarization, inside or outside a greenhouse, in Piracicaba, SP. Solarization is characterized by the placement, during the period of higher insolation, of a plastic sheet over humid soil in order to raise its temperature.

Erradication of Rhizoctonia solani was accomplished in both environments by solarization for variable periods of time, ranging from 20 to 30 days inside the greenhouse and from 40 to 45 days in the outher area. The period necessary for the pathogen inactivation, considering both soil depths measured (10 and $20 \mathrm{~cm}$ ) was proportional to the soil temperature attained during solarization. Inside the greenhouse solarization was favored by the smaller heat loss that occurs in this condition, especially at night.

Pythium aphanidermatum was not consistently controlled by solarization in both environments. In some experiments the pathogen viability was reduced in the layers closer to the surface; on the other hand, the pathogen growth was favored at 20 $\mathrm{cm}$ depth in the solarized plots.

In addition, in vivo and in vitro experiments were carried out to select isolates of Trichoderma spp. which were antagonists to those pathogens. In these trials two isolates of Trichoderma spp. were selected, one antagonist to Pythium aphanidermatum and the other to Rhizoctonia solani. The control of the pathogens promoted by the Trichoderma isolates, however, was less effective than that of the chemical method, which included very efficient fungicides, specific for each pathogen: metalaxyl + mancozeb for $P$. aphanidermatum and pencycuron for $R$. solani. 
A subsequent study was conducted to evaluate the effect of the integration of solarization with biological and chemical control, by the use of isolates selected in the previous experiments as well as the application of fungicides specific to each pathogen, in solarized and non solarized soils, obtained inside or outside the greenhouse. The integration of solarization with biological and chemical treatments did not amplify the control of the pathogens evaluated. For $P$. aphanidermatum the incorporation of the antagonist to the solarized soil did not cause a reduction in the viability of the pathogen; the chemical control was very efficient in both solarized and non-solarized soils, even when half the recommended rate was applied. For $R$. solani, solarization was so efficient that the chemical or biological control treatments did not bring any additional beneficial effects. 


\section{INTRODUÇÃO}

No início da década de 90 o cultivo protegido de hortaliças apresentou rápida expansão no Brasil. As culturas nestas condições permitem obter, quando bem conduzidas, produtividade, precocidade, rendimento econômico e produtos de qualidade superior. Os ambientes protegidos são intensa e sucessivamente plantados com culturas de elevado valor e retomo econômico. Esta situação pode resultar em infestação destas áreas por patógenos veiculados pelo solo, como Pythium aphanidermatum e Rhizoctonia solani. Estes patógenos atacam sementeiras de hortaliças acarretando tombamento de pré e pós-emergência e, também plantas adultas, causando podridões em raízes, colo e frutos.

O controle destes microrganismos é obtido pela desinfestação de solos e substratos com brometo de metila, previsto para ser retirado do mercado em futuro próximo, pela utilização de calor úmido ou pela aplicação de fungicidas nas sementes plantadas ou nas plântulas recém-emergidas, antes e depois do transplante.

A solarização pode ser utilizada como uma alternativa para a desinfestação de solos e substratos, e consiste na colocação de um filme plástico sobre o solo umedecido por um período determinado, durante a época mais quente do ano, visando aumentar sua temperatura. A solarização também pode ser aplicada dentro de casas de vegetação, estimando-se que nestes ambientes o período de tratamento possa ser reduzido, aplicado em meses mais frios do ano ou em locais com menor insolação e temperatura. Como a expansão do cultivo protegido no Brasil é relativamente recente, a aplicação da técnica nesta condição foi pouco estudada.

Durante a solarização ocorre uma combinação de processos físicos, químicos e biológicos, que acarretam redução drástica na viabilidade de fungos fitopatogênicos, resultando em um novo equilíbrio biológico no solo. $O$ controle de patógenos veiculados pelo solo é devido, principalmente, à sua inativação térmica, resultante da combinação entre a temperatura atingida pelo solo e o tempo de exposição ao 
tratamento. A redução na incidência de doenças é conseqüência do efeito do tratamento principalmente sobre os patógenos, e também sobre outros microrganismos, o ambiente físico e químico do solo, e os hospedeiros envolvidos.

A solarização pode ser melhorada por meio da integração com outros métodos de controle, tais como biológico e químico, tendo por objetivo ampliar o efeito de ambos. Estima-se que a redução na população microbiana do solo, provocada pela solarização, possa favorecer a sua colonização por fungos antagônicos, como Trichoderma spp. Se as temperaturas atingidas forem subletais, principalmente nas camadas mais profundas do solo, pode ocorrer enfraquecimento de propágulos de fitopatógenos tornando-os mais suscetiveis ao ataque por agentes de biocontrole. A integração entre solarização e controle quimico pode permitir a redução nas doses de fungicidas aplicados ao solo e aumentar a eficiência de ambos.

A integração de técnicas de controle de patógenos veiculados pelo solo é preconizada em muitas publicações. A integração da solarização com outros métodos de controle, entretanto, foi pouco estudada, principalmente em regiões tropicais, tornando-se necessária a investigação de possiveis sinergismos e vantagens ou desvantagens da combinação de métodos de controle.

Os objetivos deste trabalho foram:

a) Avaliar a possibilidade de controle de Pythium aphanidermatum e Rhizoctonia solani em áreas intensamente cultivadas, em ambiente protegido ou não, pelo emprego da solarização.

b) Selecionar isolados de Trichoderma sp. antagônicos aos patógenos Pythium aphanidermatum e Rhizoctonia solani.

c) Verificar o efeito da integração entre a solarização e o tratamento químico ou biológico sobre a viabilidade de Pythium aphanidermatum e Rhizoctonia solani. 


\section{REVISÃO DE LITERATURA}

\subsection{Pythium aphanidermatum e Rhizoctonia solani}

Entre as hortaliças, as cucurbitáceas e, principalmente, o pepino, são as mais suscetíveis ao ataque por Pythium sp. Em condições tropicais, plântulas de pepino sofrem tombamento provocado principalmente pela espécie Pythium aphanidermatum (Messiaen et al., 1995). Esta espécie também foi considerada a mais patogênica em cultivo de pepino em substrato, em casas de vegetação (Ranking \& Paulitz, 1994). Rhizoctonia solani é um fungo que afeta sementeiras de diversas hortaliças, acarretando tombamento (Latorre, 1990), sendo agente causal desta doença em cucurbitáceas (Messiaen et al., 1995) e crucíferas. Ambos os patógenos sobrevivem no solo, apresentando grande capacidade saprofítica (Latorre, 1990). O primeiro produz oósporos (Bollen, 1985) e o segundo escleródios que aumentam sua capacidade de sobrevivência (Latorre, 1990). Em casas de vegetação, com o cultivo sucessivo de hortaliças, algumas das mais devastadoras doenças são causadas por patógenos "veiculados pelo solo, como Pythium e R. solani (Flechter, 1984). Espécies de Pythium podem provocar podridões radiculares e a podridão da coroa em pepino (Flechter, 1984; Ranking \& Paulitz, 1994). Os plantios em casas de vegetação, principalmente em substratos artificiais, propiciam as condições ideais para $o$ ataque por espécies de Pythium (Menzies et al., 1996). Rhizoctonia solani é citado como agente causal de podridão da saia em alface, que ocorre também neste ambiente (Flechter, 1984). Ambos os patógenos podem estar associados a podridões radiculares e no colo de diversas hortaliças e ornamentais cultivadas em casa de vegetação (Fletcher, 1984).

$O$ controle de espécies de Pythium e de $R$. solani pode ser obtido pela desinfestação de substratos com calor, brometo de metila ou aplicação de fungicidas nas sementes ou nas plântulas recém-emergidas, antes e depois do transplante (Fletcher, 1984). Para evitar o tombamento provocado por espécies de Pythium, 
procede-se ao tratamento das mudas com metalaxyl, fosetyl-al ou cymoxanyl (Latorre, 1990). O controle de Rhizoctonia solani pode ocorrer pelo tratamento das sementes com os fungicidas thiram ou captan, ou com aplicações localizadas no solo de PCNB ou captan (Latorre, 1990). Recentemente o produto pencycuron tem revelado grande atividade contra alguns grupos de anastomose de $R$. solani (Morton, 1994).

A aplicação de brometo de metila é uma das alternativas para desinfestação de sementeiras e de solos intensamente cultivados em casas de vegetação, apresentando a vantagem de permitir o tratamento em uma semana (Fletcher, 1984). Este produto encontra-se entre os gases apontados como responsáveis pela redução da camada de ozônio da atmosfera, onde o composto transforma-se em bromina, que reage com o ozônio, quebrando a molécula. O papel do brometo de metila utilizado na agricultura em relação à redução da camada de ozônio não está bem esclarecido; entretanto, como a maior parte do composto empregado nesta prática é volatilizada, medidas têm sido tomadas visando a reduzir sua utilização. O protocolo de Montreal, firmado em 1987 e assinado por mais de 150 países, propõe que as substâncias que reduzem a camada de ozônio tenham sua produção interrompida. Os países responsáveis por este protocolo se reuniram novamente em 1995, propondo que a produção de brometo de metila seja interrompida em 2.010 , com uma redução de $25 \%$ em 2001 e de 50\% em 2005. Os países em desenvolvimento pretendem estabilizar o consumo em 2001 com base no consumo médio registrado nos anos de 1995 a 1998 (Ristaino \& Thomas, 1997).

\subsection{Solarização}

A solarização pode ser apontada como uma alternativa ao controle de patógenos veiculados pelo solo. É um processo que consiste na colocação de um filme plástico sobre o solo umedecido durante o período do ano de maior radiação solar, com o objetivo de promover o aumento da sua temperatura. A solarização aquece o solo através de ciclos repetidos diariamente. Durante o processo, a temperatura atinge níveis que são letais nas camadas superficiais e subletais nas camadas mais profundas do solo a muitos fitopatógenos e plantas daninhas, provocando alterações biológicas, químicas e físicas, resultando, freqüentemente, em aumento de produção das culturas (Katan \& De Vay, 1991; Souza, 1994). O principal objetivo da solarização 
é o controle de patógenos veiculados pelo solo antes do plantio, mas o processo pode ser acompanhado por um controle de patógenos secundários e redução de substâncias tóxicas, acarretando aumento de produção e freqüentemente prolongando o uso de terras agricultáveis (Katan \& De Vay, 1991). Embora a temperatura seja o fator que mais influi no tratamento, alterações microbianas induzidas pela solarização podem contribuir para o controle de doenças, principalmente nas camadas mais profundas do solo e em estações e regiões marginais. As temperaturas subletais ao enfraquecerem os propágulos de patógenos, favorecem 0 ataque por populações antagonistas (Katan, 1996).

O aumento na temperatura do solo coberto, quando comparado ao sem cobertura plástica, é de 2 a $10^{\circ} \mathrm{C}$, de acordo com a estação do ano, do tipo de solo, nivel de insolação e umidade. $\dot{A}$ noite a diferença entre ambos é menor, variando entre 2 e $4^{\circ} \mathrm{C}$ (Stevens et al., 1991). A eficiência do processo pode ser aumentada pelo emprego de uma camada dupla de plástico ou pela solarização dentro de casas de vegetação (Katan \& DeVay, 1991).

\subsubsection{Solarização dentro de casas de vegetação e dupla solarização}

Estima-se que em casas de vegetação a solarização possa ser efetuada em períodos menores e em épocas do ano menos favoráveis a este processo, e em áreas marginais, com menor temperatura média anual. Ocorre um aumento adicional na temperatura do solo graças a uma camada estática de ar entre a dupla camada plástica, que age como isolante térmico (Katan \& DeVay, 1991). A aplicação da solarização dentro de casas de vegetação precisa considerar dois aspectos contraditórios, a sua cobertura reduz a radiação total que incide sobre o solo, ao passo que as temperaturas mais altas, que prevalecem nestas condições, tendem a reduzir as perdas de calor do solo (Mahrer, 1991). A solarização dentro de casas de vegetação é empregada para diversas culturas no Japão e na Europa. Na Itália, as temperaturas máximas obtidas em casas de vegetação de vidro solarizadas, a 12 e a $25 \mathrm{~cm}$ de profundidade foram, respectivamente, 9 e $4^{\circ} \mathrm{C}$ mais elevadas que em áreas solarizadas extemamente. O número de horas em que estes solos solarizados permaneceram com temperaturas acima de $40^{\circ} \mathrm{C}$, a $12 \mathrm{~cm}$ de profundidade, foi 48,5 e 7 horas respectivamente para solo dentro e fora da estufa (Garibaldi \& Gullino, 1991). Na 
Grécia, Tjamos et al. (1989) registraram temperaturas de $50^{\circ} \mathrm{C}$ a $10 \mathrm{~cm}$ e $42{ }^{\circ} \mathrm{C}$ a 30 $\mathrm{cm}$ de profundidade dentro de casas de vegetação. Neste mesmo país foram obtidas por Bourbos \& Skoudridakis (1996), dentro de casas de vegetação, temperaturas médias máximas de 58,3 e 57,5 ${ }^{\circ} \mathrm{C}$ nos anos de 1993 e 1994, a $10 \mathrm{~cm}$ de profundidade, superiores às do solo não solarizado, com temperaturas de 49,1 e $48^{\circ} \mathrm{C}$ nesta mesma profundidade. No sul da Itália foram registradas temperaturas máximas de $51^{\circ} \mathrm{C}$ a $15 \mathrm{~cm}$ de profundidade (Cartia \& Cipriano, 1989) e no norte deste país as temperaturas máximas foram de $48^{\circ} \mathrm{C}$ para solo solarizado e de $38,9^{\circ} \mathrm{C}$ para solo não solarizado (Garibaldi \& Tamieti, 1989). A solarização de canteiros elevados dentro de casas de vegetação resultou em temperaturas máximas de $45^{\circ} \mathrm{C}$ a $15 \mathrm{~cm}$ de profundidade (Gulino et al., 1998). Os experimentos em casas de vegetação revelaram controle de patógenos como Pyrenochaeta terrestris (Cartia \& Cipriano, 1989), Verticillium dahliae (Tjamos et al., 1989), F. oxysporum f.sp. basilici (Gulino et al., 1998), além de aumentos muito significativos na produção e qualidade de hortaliças.

A solarização dentro de casas de vegetação pode ser comparada à dupla solarização, em que se sobrepõe o solo solarizado como um outro filme plástico, mantendo-se uma camada estática de ar entre ambos com o objetivo de reduzir as perdas de calor. Raymundo \& Alcazar (1986) obtiveram temperatura máxima de $60^{\circ} \mathrm{C}$ a $10 \mathrm{~cm}$ de profundidade, $12,5^{\circ} \mathrm{C}$ mais alta que a temperatura sob uma camada simples de plástico. A dupla solarização de substratos de sementeiras, na Austrália, resultou em temperaturas máximas de $51^{\circ} \mathrm{C}$ sob camada dupla e $44,6^{\circ} \mathrm{C}$ sob camada simples de plástico, a $25 \mathrm{~cm}$ de profundidade (Duff \& Connelly, 1993). A dupla solarização de sementeiras de espécies florestais, na França, resultou em temperaturas máximas de $49,9^{\circ} \mathrm{C}$ a $5 \mathrm{~cm}$ e de $44^{\circ} \mathrm{C}$ a $15 \mathrm{~cm}$ de profundidade (Le Bihan et al., 1997).

Por meio da dupla solarização obteve-se o controle de nematóides (Raimundo \& Alcazar, 1986) e a redução de 97 a $98 \%$ no inóculo de Fusarium oxysporum f.sp. vasinfectum, ao passo que o tratamento com apenas um filme plástico diminuiu 0 inóculo em 57 a 61\% (Ben-Yefet et al., 1987). Com a dupla solarização foi possivel a redução no periodo de tratamento, pois propágulos de Pythium myriotylum, Phytophthora nicotianae var. nicotianae e Sclerotium rolfsii, enterrados a $25 \mathrm{~cm}$ de profundidade, foram eliminados entre 2 e 8 dias após o inicio da dupla solarização na primavera, verão e outono e entre 4 e 20 dias sob camada simples de plástico (Duff \& Connelly, 1993). 


\subsubsection{Solarização para o controle de Pythium aphanidermatum e Rhizoctonia solani}

A temperatura do solo é a variável que mais influi no processo de desinfestação (Souza, 1994). Bollen (1985) demonstrou que muitas espécies de Pythium e Phytophthora são relativamente sensiveis ao calor, embora Pythium aphanidermatum tenha sido a espécie mais resistente, inclusive porque forma grande quantidade de oósporos em meio de cultura. A temperatura letal a $P$. aphanidermatum, após 30 minutos de exposição, em cultura em solo, é maior que $52,5^{\circ} \mathrm{C}$. Pullman et al. (1981) verificaram que há uma relação logaritmica entre a temperatura letal e o tempo de exposição ao calor constante para diversos patógenos, inclusive Pythium ultimum e Rhizoctonia solani. A inativação térmica do primeiro patógeno ocorreu mais lentamente que do segundo, sendo de 34 minutos a $50^{\circ} \mathrm{C}, 180$ minutos a $47^{\circ} \mathrm{C}, 9$ horas a $45^{\circ} \mathrm{C}, 45$ horas a $42^{\circ} \mathrm{C}$, e 20 dias a $37^{\circ} \mathrm{C}$. Rhizoctonia solani não apresentava viabilidade após 12 minutos a $50^{\circ} \mathrm{C}, 55$ minutos a $47^{\circ} \mathrm{C}, 33$ horas a $42^{\circ} \mathrm{C}$ e 14 dias a $39,1^{\circ} \mathrm{C}$. Lefèvre \& Souza (1993) obtiveram inativação térmica deste patógeno pela exposição do micélio à temperatura de $50^{\circ} \mathrm{C}$ por 30 minutos. Silva et al. (1996) verificaram que a sensibilidade térmica de micélio e escleródios de isolados de $R$. solani era semelhante e esteve em torno de $49^{\circ} \mathrm{C}$.

O controle por meio da solarização pode ser variável, de acordo com a espécie de Pythium envolvida. A colonização de raizes de Gypsophila por Pythium sp. foi totalmente reprimida pela aplicação da solarização no solo infestado de casas de vegetação em Israel (Gamliel et al., 1989). Bettiol et al. (1994) obtiveram controle de Pythium sp., com eficiência equivalente à do controle químico, através da solarização de canteiros utilizados para o plantio de crisântemo. A dupla solarização e a solarização simples de substratos de sementeiras, na Austrália, resultaram em controle de Pythium myriotilum em amostras enterradas a $25 \mathrm{~cm}$ de profundidade no verão; entretanto, ambos os tratamentos não foram eficientes no inverno (Duff \& Connely, 1993). Pythium spp. foram controlados apenas com solarização dupla em túneis plásticos, não sendo inativados pela solarização simples, em Valência, na Espanha (Cebolla et al., 1995), e nas camadas superficiais em sementeiras de espécies florestais na França (Le Bihan et al., 1997). Stapleton \& De Vay (1995) incluem 
Pythium ultimum entre os patógenos controlados pela solarização e $P$. aphanidermatum entre os patógenos parcialmente ou não controlados por este tratamento. O controle de Pythium aphanidermatum em solo infestado foi obtido após dois dias de exposição à solarização em coletor solar, com temperatura máxima de 80 ${ }^{\circ} \mathrm{C}$ (Ghini, 1993). Pythium aphanidermatum foi controlado também em plântulas de melancia após 30 dias de exposição à solarização no Irã (Mansoori \& Jaliani, 1996), com temperaturas máximas de $49^{\circ} \mathrm{C}$.

Rhizoctonia solani está incluido entre os patógenos controlados pela solarização (Stapleton \& De Vay, 1995). A solarização por 14 dias nos meses mais quentes do ano, promoveu o controle de $R$. solani, entre outros patógenos, em solo cultivado com algodão (Pullman et al., 1981). Este patógeno também foi controlado em substrato infestado, utilizado para o plantio de gerbera, após 3 semanas de solarização, nos meses de janeiro e fevereiro na Austrália (Kaewruang et al., 1989). Em coletor solar desenvolvido por Ghini \& Bettiol (1991), o fungo $R$. solani foi controlado com apenas dois dias de exposição, tendo o solo atingido a temperatura máxima de $66^{\circ} \mathrm{C}$ (Ghini et al., 1992). A solarização de casas de vegetação na Itália, nos meses mais quentes do ano, reduziu significativamente a viabilidade de propágulos de R. solani (Garibaldi \& Tamietti, 1989). A solarização em canteiros elevados no interior de casas de vegetação por aproximadamente 40 dias controlou este patógeno na Itália (Gulino et al., 1998). Em sementeiras de espécies florestais este fungo foi controlado apenas com dupla solarização e nas camadas mais superficiais do solo, após 4 a 7 semanas de tratamento (Le Bihan, 1997). Este patógeno, entretanto, não foi controlado com solarização simples e foi parcialmente controlado após 30 dias sob solarização dupla em túneis plásticos na Espanha (Cebolla et al., 1995).

\subsection{Integração da solarização com controle biológico}

A redução na viabilidade de patógenos veiculados pelo solo pode ser ampliada pela aplicação da solarização integrada a outros métodos de controle, como biológico e químico. Através de uma abordagem integrada pode-se reduzir o tempo gasto na solarização e permitir a sua aplicação em áreas com menor insolação (Davis, 1991). A integração da aplicação de espécies de Trichoderma, habitantes que se 
multiplicam no solo, com o controle físico, químico ou cultural pode garantir, a longo prazo, o controle de patógenos de solo (Chet, 1987).

Em geral, após a solarização, sobrevive ao tratamento uma população residual, composta principalmente por "agentes de biocontrole", como Pseudomonas fluorescentes e diversos fungos (Griffin \& Baker, 1991). Caso ocorra, entretanto, sobrevivência de patógenos, principalmente nas bordas das áreas tratadas, estes tenderão a se multiplicar. Como ocorreu uma ruptura no equilíbrio biológico e na capacidade tampão do solo, as doenças provocadas pelos mesmos poderão se acentuar (Griffin \& Baker, 1991). Pode haver, também, uma reinvasão de solos tratados com patógenos como Pythium spp. e Rhizoctonia solani, que apresentam elevada competitividade e capacidade saprofítica (Griffin \& Baker, 1991). Um outro importante fator é que o tratamento do solo com calor pode erradicar ou enfraquecer os patógenos. O propágulos enfraquecidos apresentam menor capacidade de germinar, maior sensibilidade à fungistase e menor potencial de inóculo, tornando-se mais suscetíveis à ação de agentes de biocontrole. A reinfestação por agentes de biocontrole pode ser uma estratégia para recuperar o poder tampão e aumentar a supressividade do solo a fitopatógenos (Griffin \& Baker, 1991). A combinação da solarização com outros métodos de controle pode ampliar o efeito de ambos (Katan, 1996) e entre as combinações, a da solarização com a introdução de agentes de biocontrole é especialmente atraente (Katan, 1996).

\subsubsection{Trichoderma spp. no controle biológico}

Espécies de Trichoderma são comuns em quase todos os solos sendo antagonistas a outros fungos (Chet, 1987; Papavizas, 1985). A introdução de agentes de biocontrole é em geral favorecida por tratamentos que reduzem a população de microrganismos no solo (Tjamos et al, 1992). O tratamento com calor úmido (vapor) ou solarização pode modificar o solo, favorecendo a colonização por espécies de Trichoderma e Gliocladium (Papavizas, 1985). Em solo desinfestado com brometo de metila, Trichoderma spp. é o antagonista que primeiro se destaca, pois tem poucos competidores e se multiplica rapidamente (Munnecke et al., 1984, citado por Chet, 1987). A aplicação de $T$. harzianum em solo desinfestado com brometo de metila aumentou o controle e preveniu a reinfestação por $R$. solani em cultura de amendoim 
(Chet, 1987). T. harzianum cresceu abundantemente sobre solo fumigado com brometo de metila, apresentando população bem maior que em solo não fumigado, 19 semanas após adição ao solo do antagonista (Cole \& Zvenyika, 1988).

Espécies de Trichoderma têm sido testadas para o controle de Pythium spp. em diversas culturas. O controle de tombamento provocado por Pythium spp. em ervilha foi obtido pelo tratamento das sementes com T. hamatum (Harman et al., 1980). $T$. harzianum foi utilizado para o controle de $P$. ultimum em pepino (Harman et al., 1989; Wolfheckel \& Jensen, 1992) e, em outras culturas (Harman et al., 1989). P. aphanidermatum foi parcialmente controlado em pepino, ervilha e tomate com esta mesma espécie de Trichoderma (Sivan et al., 1984).

Obteve-se o controle de $R$. solani por isolados de Trichoderma em vários experimentos, com diversas culturas. A aplicação de $T$. hamatum em sementes (Harman et al., 1980) e no solo (Chet \& Baker, 1981) promoveu o controle de $R$. solani em rabanete. T. harzianum aplicado no solo resultou em controle deste patógeno em plântulas de berinjela, tomate, feijão (Hadar et al., 1979), fumo (Cole \& Zvenyika, 1988) e bico-de-papagaio (Elmer \& Elliott, 1998), e alguns isolados de Trichoderma spp. reduziram o ataque por este patógeno em plântulas de feijão em casa de vegetação (Noronha et al., 1996). Coley-Smith et al. (1991) obtiveram controle de $R$. solani em plantas jovens e adultas de alface em túneis plásticos com dois isolados, de $T$ viride e T. harzianum. Em trabalhos recentes, produtos comerciais com formulação baseada em espécies de Trichoderma têm sido empregados, principalmente, em substrato padronizado. BINAB-T, um produto comercial formulado com $T$. viride, reduziu significativamente a incidência de podridão do pé provocada por $R$. solani em crisântemo (Orlikowski \& Wojdyla, 1996), e Soilgard (formulado com G. virens) e BioTrek (formulado com $T$. harzianum), reduziram o tombamento provocado por este patógeno em zinia, sendo o primeiro mais eficiente (Walter \& Bruette, 1996).

Para a obtenção de isolados de Trichoderma spp. antagônicos a patógenos como $P$. aphanidermatum e $R$. solani, procede-se à seleção que, em geral, envolve fases in vitro e in vivo. Os testes em laboratório são mais fáceis e rápidos, que os efetuados com solo, que consomem tempo, recursos e espaço (Elad et al., 1981) mas freqüentemente os resultados obtidos in vitro não apresentam correlação com os obtidos em testes in vivo (Tronsmo, 1996). Embora não apresentem resultados equivalentes, os testes em laboratório podem reduzir os efetuados com solo, pois 
Broadbent et al. (1971, citado por Fravel, 1988) ao testar 3500 microrganismos para antibiose in vitro observou que $40 \%$ destes inibiam um ou mais dentre 9 patógenos estudados, entretanto, só $4 \%$ destes foram efetivos no solo. Microrganismos sem atividade antagônica in vitro, também não apresentaram atividade no solo. Os testes in vitro são necessários, também, porque os organismos selecionados precisam se multiplicar e esporular abundantemente em meios baratos, além de produzir propágulos que sobrevivam ao armazenamento (Tronsmo, 1996). O sucesso da seleção, porém, só pode ser comprovado sob condições naturais (Tronsmo, 1996).

Diversas revisões foram realizadas abordando o modo de ação de Trichodema spp. como agente de biocontrole (Papavizas, 1985; Chet, 1987; Melo, 1996). O processo de parasitismo é complexo, envolvendo o tropismo em direção ao fungo hospedeiro, o enrolamento da hifa no mesmo, a degradação da parede e a penetração (Chet, 1987). Uma grande gama de antibióticos é produzida por espécies deste gênero in vitro tais como, tricorzianina, isonitrinas, pirona, antraquinona, piridona - produzidos por $T$. harzianum; tricotoxina, alameticina, produzidos por $T$. viride ; isonitrinas e pirona - produzidos por T. hamatum (Melo, 1996), além de tricodermina produzido por $T$. viride e T.polisorum (Denis \& Webster. 1971). Entre os mecanismos de atuação deste fungo mais estudados estão a produção de enzimas extracelulares, como quitinases, celulases, ß-1-3-glucanases, B-1-4-glicosidase, e proteases, associadas ao processo de parasitismo por provocarem, principalmente, a degradação das paredes dos patógenos (Melo, 1996). Elad et al. (1983), observaram, em microscópio eletrônico, o parasitismo de $R$. solani por $T$. harzianum e $T$. hamatum, e constataram enrolamento das hifas e degradação da parede. Nos locais de degradação ocorreu a produção de ß-1-3-glucanases e de quitinases. $O$ crescimento das hifas de $T$. harzianum e de $T$. hamatum parece ser direcionado ao micélio de $R$. solani (Chet \& Baker, 1981). A liberação de endo-1,3-ß-glucanases e de celulases foi observada por Thrane et al. (1997) ao parear T. harzinum e Pythium spp.

No solo, o mecanismo de ação é mais complexo, podendo ocorrer competição por nutrientes e fungistase, a qual previne a formação de antibióticos e enzimas, ou as inativa assim que são formadas (Lewis \& Papavizas, 1991). A adição dos isolados de Trichoderma ou Gliocladium na forma de micélio/conídios associados a uma base alimentar tende a reduzir a fungistase, aumentando o efeito antagônico dos mesmos e melhorando a colonização do solo (Papavizas, 1985). 


\subsubsection{Aplicação de Trichoderma spp. e solarização}

A integração da solarização com o recobrimento de bulbos de íris com $T$. harzianum resultou em um controle mais eficiente que ambas as técnicas isoladas, acarretando aumento de até $150 \%$ na produção em relação à testemunha (Chet et al., 1982). A aplicação de $T$. harzianum associado à solarização em campos de batata infestados com $R$. solani aumentou o controle da doença e do patógeno e atrasou a reinfestação do solo pelo fungo (Davis, 1991). Apenas a solarização foi eficiente no controle de $R$. solani em feijoeiro e de Pythium ultimum em pepino e a combinação da aplicação de $T$. harzianum e solarização ampliou o controle em alguns ensaios, porém, sem diferenças estatísticas (Minuto et al., 1995). O aquecimento à temperatura subletal do solo favoreceu a colonização por $T$. viride, com a conseqüente supressão de murcha de fusarium em crisântemo (Marois \& Locke, 1985, citados por Papavizas, 1985). Em solo naturalmente infestado com Sclerotium cepivorum, a integração da solarização com aplicação de $T$. harzianum resultou num efeito sinergístico com o controle quase total do patógeno, o que não foi obtido apenas com a solarização (Pereira et al., 1996). Em experimentos dentro de casas de vegetação, a solarização foi tão eficiente que a incorporação de Trichoderma, após a solarização, não resultou em aumento no controle de $R$. solani (Garibaldi \& Tamieti, 1989). A aplicação de Trichoderma, entretanto, deve ser efetuada depois da solarização, pois este fungo, assim como Gliocladium virens, pode ser inativado pelas temperaturas atingidas pelo solo (Ristaino et al., 1991; Pereira et al., 1996). 


\section{MATERIAL E MÉTODOS}

\subsection{Solarização do solo}

\subsubsection{Preparo das amostras com Pythium aphanidermatum e Rhizoctonia solani}

Solo naturalmente infestado com Pythium aphanidermatum foi coletado na área experimental do Departamento de Entomologia, Fitopatologia e Zoologia Agrícola da ESALQ/USP, 10 a 15 dias antes do início dos experimentos, tendo sido seco à sombra, peneirado e colocado em saquinhos de tela de nylon $(0,5$ litro de solo peneirado por saquinho).

Foi utilizado, para os experimentos, um isolado de Rhizoctonia solani do grupo de anastomose AG-4, procedente do município de Pompéia, que vinha sendo mantido em solo autoclavado. Este isolado apresentou a capacidade de formar rapidamente escleródios em laboratório, 4 a 5 dias após a repicagem. Foram adicionados discos de micélio de $R$. solani a sementes de trigo umedecidas $(100 \mathrm{~g}$ de sementes de trigo/75 $\mathrm{mL}$ de água) e autoclavadas por 1 hora a $120^{\circ} \mathrm{C}$ em 2 dias consecutivos. As sementes foram incubadas por 7 dias, até serem recobertas pelo micélio do patógeno, sendo então misturadas a solo autoclavado $\left(1,5 \mathrm{~atm}, 120^{\circ} \mathrm{C}\right.$ por 3 horas $)$ e ambos colocados em saquinhos de tela de nylon $(250 \mathrm{ml}$ de solo e aproximadamente $6 \mathrm{~g}$ de sementes por saquinho). Durante o transcorrer dos experimentos, o isolado foi mantido em água ou em tubos com BDA.

Para cada patógeno separadamente, foram preparadas amostras compostas. Estas consistiram de dois saquinhos de tela de nylon contendo propágulos de cada patógeno, amarrados a um cordão plástico, com uma distância de $10 \mathrm{~cm}$ entre os mesmos, para permitir que os saquinhos fossem enterrados em duas profundidades, 10 e $20 \mathrm{~cm}$. 


\subsubsection{Experimentos de solarização}

Os experimentos de solarização foram conduzidos em parte de uma casa de vegetação cercada lateralmente com tela, com teto coberto com filme plástico transparente (150 $\mu \mathrm{m}$ de espessura e proteção anti-UV), e em campo aberto, ambos da área experimental do Departamento de Produção Vegetal da ESALQ-USP.

A técnica de solarização utilizada para todos os experimentos consistiu na colocação de um filme plástico transparente (100 $\mu \mathrm{m}$ de espessura) sobre o solo previamente umedecido, com as laterais enterradas para evitar ventilação e manter a temperatura em seu interior. Todas as parcelas não solarizadas foram umedecidas após a instalação dos experimentos e, periodicamente, durante sua condução.

Cada amostra composta (item 3.1.1) foi etiquetada e disposta de maneira casualizada sobre as áreas a serem solarizadas ou não, dentro e fora da casa de vegetação, mantendo uma distância mínima de $40 \mathrm{~cm}$ das bordas. Nestes locais foram cavados buracos com $20 \mathrm{~cm}$ de profundidade e os saquinhos com propágulos de ambos os patógenos, enterrados a 10 e a $20 \mathrm{~cm}$ de profundidade, colocando-se terra suficiente para evitar contato entre os mesmos.

\subsubsection{Experimentos 1 e 2}

Uma área de 14 metros de comprimento por 8 metros de largura da casa de vegetação teve as paredes laterais vedadas com plástico transparente (100 $\mu \mathrm{m}$ de espessura), para aumentar a temperatura no seu interior. Parte desta área $(7 \times 7$ metros) teve o solo umedecido e solarizado e outra parte, de igual tamanho, foi umedecida, mas permaneceu sem cobertura plástica. A 30 metros da estufa, uma área em campo aberto com igual dimensão teve parte solarizada ( $7 \times 7$ metros) e outra permaneceu sem plástico.

Em cada área, solarizada ou não solarizada, dentro e fora da casa de vegetação, foram enterradas 9 amostras compostas (item 3.1.1) contendo solo infestado com $P$. aphanidermatum e outras 9 amostras, também compostas, contendo 
propágulos de $R$. solani. Aproximadamente 20,30 e 40 dias após a instalação dos experimentos foram retiradas, de cada área, 3 amostras compostas de cada patógeno.

Foi realizada uma análise exploratória dos dados utilizando-se um modelo fatorial sendo o fator 1 , ambiente (dentro e fora da casa de vegetação); o fator 2 , solarização, (com e sem), o fator 3 , a profundidade de colocação das amostras (a 10 e a $20 \mathrm{~cm}$ ) e o fator 4 período de solarização (20,30 e 40 dias). Para a análise utilizou-se a média das três amostras repetidas para cada fator.

Os experimentos 1 e 2 foram instalados no verão. As datas de instalação, coleta das amostras, assim como as datas de avaliação das temperaturas do solo, às 8:00 e às 15:00 horas, por meio de termômetros de solo, são mostradas na Tabela 1.

Tabela 1. Datas de instalação, coleta de amostras com propágulos dos patógenos Pythium aphanidermatum e Rhizoctonia solani, e períodos de avaliação da temperatura, a 10 e a $20 \mathrm{~cm}$ de profundidade, às 8:00 e às 15:00 horas, dos experimentos 1 e 2 .

\begin{tabular}{llllll}
\hline Experimentos & \multicolumn{5}{c}{ Datas } \\
\cline { 2 - 6 } & Instalação & $1^{\text {a }}$ Coleta & $2^{\text {a }}$ Coleta & $3^{\text {a }}$ Coleta & \multicolumn{1}{c}{$\begin{array}{l}\text { Avaliação de } \\
\text { Temperatura }\end{array}$} \\
\hline Experimento 1 & $18 / 12 / 97$ & $05 / 01 / 98$ & $15 / 01 / 98$ & $26 / 01 / 98$ & 05 a 23/01/98 \\
Experimento 2 & $05 / 02 / 98$ & $26 / 02 / 98$ & $06 / 03 / 98$ & $16 / 03 / 98$ & $05 / 02$ a 16/03/98 \\
\hline
\end{tabular}

\subsubsection{Experimentos 3, 4 e 5}

Os experimentos 3,4 e 5 foram instalados em uma área da mesma casa de vegetação, com 28 metros de comprimento e 8 metros de largura, também vedada lateralmente com plástico transparente. Para estes experimentos, a área foi dividida em 4 blocos com $14 \times 3,5$ m sendo cada bloco subdividido em sub-parcelas, uma solarizada e outra não, cada sub-parcela constando de $7 \times 3,5 \mathrm{~m}$. Em área externa ao lado da casa de vegetação efetuaram-se os mesmos tratamentos.

Em cada subparcela foram enterradas 3 amostras compostas contendo solo infestado com $P$. aphanidermatum e 3 amostras, também compostas, contendo propágulos de $R$. solani. Aproximadamente 15,30 e 45 dias após a instalação dos 
experimentos foi coletada, de cada subparcela, uma amostra composta de cada patógeno.

$O$ delineamento destes experimentos foi em fatorial sendo o fator 1 , ambiente (dentro e fora da casa de vegetação); o fator 2 , solarização, (com e sem); o fator 3 , a profundidade de colocação das amostras (a 10 e a $20 \mathrm{~cm}$ ) para cada período de solarização (15, 30 e 45 dias). Blocos, solarização, cobertura e profundidade foram hierarquizados em relação ao ambiente. A comparação entre os periodos e as interações entre períodos e demais fatores foram analisadas com medidas repetidas em relação ao tempo, comparando-se as médias pelo valor de $\mathrm{F}$ obtido no teste de Wilks-Lambda. Para análise dos experimentos foi utilizado o PROC GLM do programa SAS -Sistems for linear models (Littel et al., 1991).

Estes experimentos foram conduzidos durante o verão e início do outono dos anos de 1998 e 1999. As datas de instalação, coleta das amostras, assim como as datas de avaliação das temperaturas do solo, a 10 e a $20 \mathrm{~cm}$ de profundidade, determinadas às 15:00 horas, por meio de termômetros de solo, são apresentadas na Tabela 2.

Tabela 2. Datas de instalação, coleta de amostras com propágulos dos patógenos Pythium aphanidermatum e Rhizoctonia solani, e períodos de avaliação da temperatura, a 10 e a $20 \mathrm{~cm}$ de profundidade, às 15:00 horas, dos experimentos $3,4,5$ e 6 .

\begin{tabular}{|c|c|c|c|c|c|}
\hline \multirow[t]{2}{*}{ Experimentos } & \multicolumn{5}{|c|}{ Datas } \\
\hline & Instalação & $1^{\text {a }}$ Coleta & $2^{a}$ Coleta & $3^{\text {a }}$ Coleta & $\begin{array}{l}\text { Avaliação de } \\
\text { Temperatura }\end{array}$ \\
\hline Experimento $3^{1}$ & $24 / 11 / 98$ & $10 / 12 / 98$ & $21 / 12 / 98$ & $07 / 01 / 99$ & $\begin{array}{l}30 / 11,2,4,9,11,14 \\
16,21 \text { e } 28 / 12 / 99\end{array}$ \\
\hline Experimento $4^{2}$ & $29 / 01 / 99$ & $12 / 02 / 99$ & $26 / 02 / 99$ & $11 / 03 / 99$ & $\begin{array}{l}29 / 01,1,3,5,8,10 \\
19,22,24,26 / 02,3 \\
5 \text { e } 10 / 03 / 99\end{array}$ \\
\hline Experimento 5 & 28/02/99 & 11/03/99 & 25/03/99 & $16 / 04 / 99$ & $\begin{array}{l}3,5,10,12,15,26 \\
29 / 03 \text { e } 01 / 04 / 99\end{array}$ \\
\hline
\end{tabular}




\subsubsection{Avaliação da viabilidade dos patógenos}

As metodologias para avaliação da viabilidade de $P$. aphanidermatum e de $R$. solani foram utilizadas em todos os experimentos de solarização.

Viabilidade de $\boldsymbol{P}$. aphanidermatum - As amostras coletadas e secas em temperatura ambiente permaneceram em laboratório até a última coleta, sendo a seguir instalados os experimentos em casa de vegetação, em Campinas, para avaliação da viabilidade do patógeno.

A viabilidade de $P$. aphanidermatum foi verificada por meio de teste biológico, avaliando-se a patogenicidade do mesmo sobre plântulas de pepino, segundo metodologia adaptada de Lourd et al. $(1986,1987)$. Sementes de pepino da variedade Caipira foram plantadas em caixas plásticas de $20 \times 30 \times 15 \mathrm{~cm}$ (100 sementes/caixa) contendo aproximadamente $1,5 \mathrm{~L}$ de solo desinfestado (autoclavado a $120{ }^{\circ} \mathrm{C}$ por 3 horas) e umedecido. $O$ solo de cada saquinho desenterrado foi misturado a farinha de aveia (20 g/L de solo) e adicionado sobre cada uma das caixas contendo plântulas de pepino, na fase de cotilédones abertos. Três a sete dias após a inoculação foi contado o número de plântulas tombadas e determinada a porcentagem de tombamento e de plântulas sobreviventes.

Viabilidade de $\boldsymbol{R}$. solani - As amostras contendo propágulos de $\boldsymbol{R}$. solani foram processadas imediatamente após sua coleta. As sementes de trigo previamente colonizadas com o patógeno foram retiradas manualmente das amostras, sendo a seguir lavadas, secas em papel de filtro esterilizado e colocadas em placas de Petri contendo meio de cultura de ágar-água (10 sementes por placa, 4 placas por amostra). Dois dias após a incubação, as placas foram observadas em microscópio estereoscópico para verificar a presença de hifas típicas de $R$. solani, indicativas da sobrevivência do fungo. A seguir foi calculada a porcentagem de sementes com o patógeno. 


\subsection{Integração da solarização com controle biológico e químico}

\subsubsection{Obtenção dos isolados de Trichoderma sp. antagônicos a Pythium aphanidermatum e Rhizoctonia solani}

Para o isolamento de espécies de Trichoderma antagônicas foram utilizadas iscas, segundo metodologia adaptada de Ghini \& Kimati (1989).

Os isolados de $P$. aphanidermatum foram obtidos a partir de colo e raízes de plântulas de pepino com sintomas de "tombamento", obtidas no experimento 1 de solarização. As regiões das plantas afetadas pelo patógeno foram lavadas com água destilada, desinfestadas superficialmente com hipoclorito de sódio a $3 \%(\mathrm{v} / \mathrm{v})$ por cinco minutos, secas em papel de filtro e plaqueadas em meio de cultura de ágar-água. Dois a três dias depois, transferiu-se o patógeno para placas de Petri contendo BDA. Alguns isolados foram enviados ao Instituto de Botânica, para a identificação da espécie do patógeno. $O$ isolado de $R$. solani foi o mesmo utilizado nos experimentos de solarização, que vinha sendo mantido em BDA.

Para o preparo das iscas, discos de micélio de ambos os patógenos foram adicionados a sementes de trigo autoclavadas as quais foram incubadas por 5 dias em condição ambiente. As iscas foram constituídas por sementes de trigo (cada semente resultou em uma isca) recobertas pelo micélio de $P$. aphanidermatum e $R$. solani. As iscas foram distribuídas em placas de Petri (10 iscas por placa) contendo amostras de solo rico em matéria orgânica, retiradas de vários locais do Instituto Biológico e da ESALQ-USP. As placas foram incubadas por 7 a 10 dias em temperatura ambiente sob luz fluorescente constante. Após este período as iscas foram observadas em microscópio estereoscópico para constatar o crescimento de micélio com esporulação abundante, de coloração verde a branca, típico de Trichoderma sp. O micélio com esporos foi transferido para placas de Petri contendo BDA, obtendo-se, após sucessivas repicagens, isolados puros do fungo. Outros isolados de Trichoderma foram retirados, também sob microscópio estereoscópico, de sementes previamente enterradas com $R$. solani, nos experimentos de solarização, após sua incubação em ágar-água. Estes últimos, após a obtenção de isolados puros, foram identificados com números seguidos pela letra $S$ (solarização). Todos os isolados foram mantidos em BDA e água, em temperatura ambiente no laboratório. 


\subsubsection{Seleção in vitro}

\subsubsection{Crescimento de $P$. aphanidermatum e $R$. solani em cultivo pareado com isolados de Trichoderma spp.}

Realizou-se o pareamento de $P$. aphanidermatum e $R$. solani com isolados de Trichoderma spp. de acordo com metodologia sugerida por Bell et al. (1982). Em metade de placas de Petri contendo BDA foram colocados discos de micélio dos isolados de $P$. aphanidermatum ou $R$. solani e, na outra metade, os isolados de Trichoderma spp. a serem testados. O desenvolvimento do microrganismo patogênico e do antagônico foi avaliado 5 dias depois pela escala adaptada de Bell et al. (1982) por May (1991) com as seguintes classes:

Classe 1 = Trichodema cresce sobre o patógeno e ocupa toda a superfície do meio;

Classe 2 = Trichoderma cresce sobre pelo menos $2 / 3$ da superfície do meio;

Classe 3 = Trichoderma e $\circ$ patógeno ocupam aproximadamente metade da superfície do meio,

Classe 4 = Trichodema cresce sobre $1 / 3$ da superfície do meio,

Classe 5 = Trichoderma não cresce e o patógeno ocupa toda a superfície da placa.

Os isolados de Trichoderma foram pareados em 7 diferentes experimentos, numerados de 6 a 12, realizados à medida em que se formava um bloco de isolados puros (sem contaminação). O delineamento experimental foi inteiramente casualizado, os tratamentos constituídos por isolados, com três repetições por isolado, sendo considerada cada placa uma repetição. Durante a condução dos experimentos as placas foram mantidas em laboratório sob luz fluorescente constante. Os períodos de condução dos experimentos, bem como os isolados testados estão descritos na Tabela 3. 
Tabela 3. Isolados testados e data de realização dos experimentos de pareamento de isolados de Trichoderma spp. com Pythium aphanidermatum e Rhizoctonia solani.

\begin{tabular}{|c|c|c|}
\hline Experimentos & $\begin{array}{l}\text { Isolados de Trichoderma testados }{ }^{1} \\
\text { (número) }\end{array}$ & Datas \\
\hline Experimento 6 & $1,2,3,4,5,6,7,8,9,10,11$ & 06 a $11 / 07 / 98$ \\
\hline Experimento 7 & $12,13,14,15,17,18,19,20,22,23$ & 14 a 19/08/98 \\
\hline Experimento 8 & $24,25,26,27,28,29$ & 17 a $22 / 08 / 98$ \\
\hline Experimento 9 & $17,30,33,34$ & 20 a 25/08/98 \\
\hline Experimento 10 & $1 S, 2 S, 3 S, 4 S, 5 S, 6 S$ & $28 / 09$ a 03/10/98 \\
\hline Experimento 11 & $\begin{array}{l}10 S, 11 S, 12 S, 14 S, 15 S, 16 S, 17 S \\
18 S, 19 S, 20 S, 21 S\end{array}$ & 02 a 07/10/98 \\
\hline Experimento 12 & $22 S, 24 S, 25 S, 26 S, 27 S, 28 S, 29 S$ & $27 / 10$ a 01/11/98 \\
\hline
\end{tabular}

\subsubsection{Produção de substâncias tóxicas difusiveis por isolados de Trichoderma spp.}

Para os testes de produção de substâncias tóxicas - experimentos 13 a 16 , foram selecionados os isolados com notas menores que 2,6 frente a ambos os patógenos tendo sido também considerada sua capacidade de esporulação em BDA e em sementes de trigo autoclavadas. Também foram incluídos os isolados 8 e 13, que mostraram crescimento rápido e esporulação abundante. Embora alguns isolados (12, $15,27,28,29$ e 21S) tenham apresentado notas baixas, como não esporularam bem, e mostraram coloração clara ou setores, não foram incluídos nos demais experimentos. Para este teste foram efetuados 4 experimentos, cujos isolados testados e a data de condução encontram-se na Tabela 4

Os isolados do antagonista que apresentaram as classes de menor valor para ambos os fungos nesta primeira fase, além de outros com bom crescimento e esporulação, foram submetidos ao teste do papel celofane (Dennis \& Webster, 1971). 
Este teste foi realizado com o objetivo de verificar a difusão de substâncias tóxicas aos patógenos $P$. aphanidermatum e $R$. solani produzidas pelos isolados do antagonista em meio BDA. Placas de Petri contendo BDA, sobre o qual foi colocado papel celofane, foram autoclavadas. Discos de $4 \mathrm{~mm}$ de micélio dos isolados de Trichoderma spp. foram dispostos sobre o papel celofane, onde cresceram por 48 horas. Retirou-se cuidadosamente o papel celofane junto com o disco de Trichoderma, e, sobre a placa, foram adicionados discos de $4 \mathrm{~mm}$ de micélio de ambos os patógenos. Os diâmetros das colônias de $P$. aphanidermatum e $R$. solani foram medidos, 72 horas após sua colocação sobre as placas, tendo sido comparados aos diâmetros das colônias destes fungos crescidos em placas sem Trichoderma. Foram efetuadas 4 repetições para cada isolado e patógeno, em delineamento inteiramente casualizado. Os isolados 8 , 17,23 e 26 foram testados em mais de um experimento para verificar se mantinham a mesma capacidade de difundir substâncias tóxicas, pois os experimentos foram conduzidos em laboratório, sem controle de temperatura. No experimento 16 , realizouse um teste adicional com o preparo de 4 placas com $P$. aphanidermatum e $4 \mathrm{com} R$. solani sobre o papel celofane. Nestas placas retirou-se o papel celofane e colocou-se o mesmo patógeno ( $R$. solani após $R$. solani) para verificar se o consumo de nutrientes do meio, e não a difusão de substâncias tóxicas, poderia limitar o crescimento posterior dos microrganismos fitopatogênicos.

Tabela 4. Isolados testados e data de realização dos experimentos de difusão de substâncias tóxicas a Pythium aphanidermatum e Rhizoctonia solani produzidas por isolados de Trichoderma spp. em meio BDA.

\begin{tabular}{lll}
\hline Experimentos & $\begin{array}{c}\text { Isolados de Trichoderma } \\
\text { testados (número) }\end{array}$ & Datas \\
\hline Experimento 13 & $1,8,17,23,26$ & 07 a 11/10/98 \\
Experimento 14 & $8,17,23,34$ & 24 a 28/10/98 \\
Experimento 15 & $13,26,28,33$ & 10 a 14/11//98 \\
Experimento 16 & $3 S, 4 S, 5 S, 21 S, 28 S$ & 20 a 24/01/99 \\
\hline
\end{tabular}




\subsubsection{Seleção in vivo}

Os isolados de Trichoderma selecionados por se enquadrarem nas classes de menor valor e também por apresentarem boa esporulação tanto em BDA quanto em sementes de trigo autoclavadas, foram avaliados quanto ao comportamento in vivo no controle de $P$. aphanidermatum e $R$. solani em diversos experimentos. Todos os experimentos foram conduzidos em casa de vegetação coberta com vidro, com a parte superior e as janelas mantidas abertas, no Instituto Biológico, em Campinas, S.P.

\subsubsection{Antagonismo de isolados de Trichoderma spp. a Pythium aphanidermatum}

Foram realizados dois experimentos empregando-se plântulas de pepino recém-emergidas cultivadas em caixas plásticas com aproximadamente 90 plântulas por caixa, preparadas de acordo com a metodologia descrita no item 3.1.3.

Experimento 17 - Foi conduzido no periodo de 29/09 a 02/10/1998 com 12 tratamentos e 4 repetições, em delineamento inteiramente casualizado. Os tratamentos foram constituidos pelos isolados de Trichoderma spp. números 1, 8, 17, 23 e 26, em 2 doses -5 e $10 \mathrm{~g}$ de sementes de trigo colonizadas por litro de solo, pelo fungicida metalaxyl + mancozeb, utilizado como padrão, e pela testemunha. Os isolados de Trichoderma foram multiplicados por 10 dias em sementes de trigo autoclavadas. Para cada tratamento, cinco litros do solo naturalmente infestado por $P$. aphanidermatum foram colocados em baldes plásticos. Em cada balde foram adicionadas, em seguida, as sementes colonizadas com os isolados de Trichoderma, nas duas doses empregadas. O solo foi umedecido na proporção de 1:0,25 de solo:água. As amostras de solo correspondentes ao tratamento químico e à testemunha também foram colocadas em baldes e umedecidas, como nos demais tratamentos. Para maior colonização do solo pelo antagônico, as misturas de solo e isolado de Trichoderma, assim como o solo dos demais tratamentos, foram revolvidos a cada 2 dias, durante 8 dias. Após este periodo os solos referentes a cada tratamento receberam farinha de aveia (20 $\mathrm{g} / \mathrm{L}$ de solo) e foram colocados sobre plântulas de pepino recém-emergidas. 
Nesta ocasião foi efetuada a aplicação de metalaxyl + mancozeb (Ridomil-Mancozeb BR) nas repetições correspondentes ao tratamento químico. As quatro caixas com plântulas de pepino (repetições) foram dispostas no chão em uma área delimitada de 1 $\mathrm{m}^{2}$. A calda foi uniformemente distribuída sobre esta área por meio de regador, na dose de $300 \mathrm{~g} / 100$ litros de água com a aplicação de 2 litros de calda $/ \mathrm{m}^{2}$. O tratamento testemunha recebeu apenas solo infestado com $P$. aphanidermatum. Avaliou-se $o$ número de plântulas tombadas pelo patógeno e sobreviventes, 3 a 7 dias após a inoculação.

Experimento 18 - Realizado no período de 09 a 20/04/1999, nas mesmas condições do experimento anterior, seguindo o mesmo delineamento estatístico. Este experimento constou de 9 tratamentos, constituídos pelos isolados de Trichoderma 1 , $8,13,17,23,26,33$, adicionados ao solo infestado com $P$. aphanidermatum, na proporção de $10 \mathrm{~g}$ de sementes colonizadas por litro de solo, além da testemunha.

\subsubsection{Antagonismo de isolados de Trichoderma spp. a Rhizoctonia solani}

Experimento 19 - Foi efetuado com a cultura do rabanete, para a avaliação do antagonismo de isolados de Trichoderma spp. sobre o patógeno Rhizoctonia solani, no período de 23/04 a 03/05/99 com 11 tratamentos e quatro repetições, em delineamento inteiramente casualizado. Os tratamentos constaram da adição ao solo dos isolados de Trichoderma de números 1, 8, 13, 23, 26, 33, 17 e 28S, da aplicação do fungicida pencycuron, da testemunha e de um tratamento sem $R$. solani como padrão de emergência das sementes de rabanete. Utilizou-se solo coletado no Instituto Biológico de área anteriormente cultivada com feijão, que foi seco, peneirado e colocado em baldes ( 5 litros de solo por balde). Em cada balde foram adicionadas sementes de trigo colonizadas com $R$. solani (7 dias de incubação em laboratório), na proporção de $5 \mathrm{~g}$ de sementes colonizadas por litro de solo. Simultaneamente foram adicionadas as sementes de trigo colonizadas com os isolados de Trichoderma (10 dias de incubação em laboratório) e o solo foi umedecido $(0,5 \mathrm{~L}$ de água por $4 \mathrm{~L}$ de solo). A cada dois dias os solos foram revolvidos para melhor colonização pelo antagonista. O solo correspondente ao tratamento testemunha também foi disposto em um balde, umedecido e revolvido. Após 8 dias o solo de cada tratamento foi adicionado 
(0,2 L'vaso) sobre sementes de rabanete dispostas em vasos de barro (50 sementes/vaso). Cada vaso (20 cm de diâmetro por $15 \mathrm{~cm}$ de altura) foi previamente preenchido com um litro de solo autoclavado e considerado uma repetição. Efetuou-se o tratamento químico logo após o plantio, dispondo-se os vasos correspondentes a este tratamento ao acaso sobre uma área de $0,5 \mathrm{~m}^{2}$ delimitada no chão, efetuando-se a sua rega com uma calda preparada com pencycuron (Monceren) na dose de $100 \mathrm{~g}$ de produto comercial por 100 litros de água, e distribuída uniformemente na proporção de 4 litros de calda $/ \mathrm{m}^{2}$. Foi avaliado o tombamento de pré-emergência, com a contagem do número de plântulas emergidas, e de pós-emergência, com a contagem do número de plântulas tombadas, 4 a 10 dias após o plantio.

\subsubsection{Integração da solarização com a incorporação de Trichoderma spp. e com o controle químico}

Avaliou-se a integração da solarização com controle biológico e químico por meio de dois experimentos, dentro e fora da casa de vegetação, que foram conduzidos em duas etapas.

A primeira etapa, para obtenção das amostras solarizadas e não solarizadas, foi instalada na área experimental do Departamento de Produção Vegetal da ESALQUSP, nas mesmas parcelas dos experimentos 3, 4 e 5 de solarização, dentro e fora da mesma casa de vegetação. As amostras contendo propágulos de $P$. aphanidermatum e de R. solani foram preparadas de acordo com a metodologia descrita no item 3.1.1. Procedeu-se a solarização no periodo de 26 de fevereiro a 25 de março de 1999. Em cada parcela, com e sem plástico, dentro e fora da estufa, foram enterrados, a $10 \mathrm{~cm}$ de profundidade, 3 saquinhos de tela de nylon contendo $0,5 \mathrm{~L}$ de solo naturalmente infestado com $P$. aphanidermatum e 3 saquinhos contendo $0,5 \mathrm{~L}$ de solo misturado a sementes recobertas por micélio de $R$. solani $(10 \mathrm{~g}$ de sementes colonizadas/L de solo), os quais foram retirados após 30 dias.

A segunda fase, para avaliação dos tratamentos sobre a viabilidade de ambos os patógenos foi instalada, 15-20 dias após a coleta das amostras em casa de vegetação em Campinas, SP.

O experimento 20 foi conduzido dentro da casa de vegetação e o experimento 21 na área externa. Cada ambiente foi analisado separadamente e o delineamento dos 
experimentos foi fatorial sendo o fator 1 , solarização - com e sem solarização; o fator 2 , tratamentos - sem tratamento adicional, com controle químico e controle biológico.

Foram utilizados os isolados 26 e 17, que nos experimentos anteriores se destacaram no controle de $P$. aphanidermatum e $R$. solani, respectivamente.

Para avaliação do controle de $P$. aphanidermatum determinou-se a porcentagem de tombamento de pós-emergência de plântulas de pepino. Após a coleta das amostras, o conteúdo de cada saquinho foi colocado em um copo plástico de 0,5 L. Entre os três saquinhos coletados de cada parcela, dois saquinhos permaneceram sem tratamento adicional (um foi usado posteriormente para o tratamento químico) e o terceiro foi misturado a sementes de trigo colonizadas pelo isolado 26 de Trichoderma sp. (na proporção de $10 \mathrm{~g}$ de sementes colonizadas por litro de solo). Após a adição do antagonista ao solo, este e os demais tratamentos foram umedecidos (na proporção de $1 \mathrm{~L}$ de solo para $0,25 \mathrm{~L}$ de água) e revolvidos a cada 2 dias para melhor colonização do solo pelo antagonista. Dez dias após a adição do isolado de Trichoderma sp. ao solo, o conteúdo de cada recipiente foi misturado a farinha de aveia (20 g/L de solo) e colocado sobre plântulas de pepino recém-emergidas (aproximadamente 90 plântulas por caixa), preparadas de acordo com o item 3.1.3. Imediatamente após, as caixas correspondentes ao tratamento químico receberam aplicação de metalaxyl + mancozeb (Ridomil- Mancozeb BR), na metade da dose indicada, 150g/100 litros de água, com a aplicação de 2 litros de calda $/ \mathrm{m}^{2}$. As caixas restantes, que receberam o conteúdo do outro saquinho de cada parcela, permaneceram sem tratamento adicional. Avaliou-se a porcentagem de plântulas tombadas e sobreviventes 3 a 7 dias após a inoculação.

Para avaliação do controle de $R$. solani verificou-se a porcentagem de tombamento de pré e pós-emergência de plântulas de rabanete. Previamente o conteúdo dos saquinhos coletados foi colocado em copos plásticos, sendo os mesmos preparados de acordo com experimento 19. O isolado 17 de Trichoderma sp. foi multiplicado em sementes de trigo autoclavadas de acordo com a metodologia já descrita no experimento 17. Dez dias após a adição do isolado 17 ao solo instalou-se propriamente o experimento. Vasos de barro com $20 \mathrm{~cm}$ de diâmetro e $15 \mathrm{~cm}$ de altura receberam $1 \mathrm{~L}$ de solo autoclavado, sobre o qual foi semeado o rabanete (50 sementes/vaso). A seguir cada 2 vasos receberam o conteúdo de cada saquinho como cobertura das sementes, sendo $200 \mathrm{ml}$ para cada vaso. Cada 2 vasos constituíram 
uma repetição. Logo em seguida os dois vasos correspondentes a um saquinho de cada parcela receberam o tratamento químico, com o produto pencycuron, sendo a dose e metodologia empregadas de acordo com o experimento 19. Os vasos correspondentes ao último saquinho de cada parcela permaneceram sem tratamento adicional, constituindo as testemunhas solarizadas e não solarizadas. Avaliou-se a emergência, sete dias após o plantio, com a contagem do número de plântulas que emergiram e também, das plântulas tombadas. 


\section{RESULTADOS E DISCUSSÃO}

Como os experimentos de solarização de números 1 a 5 são semelhantes, foram discutidos em conjunto. Os demais experimentos de seleção de isolados de Trichoderma spp. e de integração da solarização com controle biológico, foram discutidos à medida em que foram apresentados os resultados.

\subsection{Solarização do solo}

\subsubsection{Experimentos 1 e 2}

\subsubsection{Temperaturas}

As temperaturas registradas nos experimentos 1 e 2 encontram-se representadas nas Figuras 1 e 2 e as temperaturas médias e máximas na Tabela 5. No experimento 1 as temperaturas médias dos tratamentos solarizados medidas às 15:00 horas, dentro da casa de vegetação e na área externa, foram semelhantes, mas, a máxima foi maior na casa de vegetação. As temperaturas médias e máximas às 8:00 horas foram superiores na casa de vegetação, a 10 e a $20 \mathrm{~cm}$ de profundidade, indicando menor perda de calor neste ambiente $\left(2-3^{\circ} \mathrm{C}\right)$. Para os tratamentos não solarizados, as temperaturas médias e máximas foram sempre superiores dentro da casa de vegetação (Figura 1).

As temperaturas médias e máximas obtidas no experimento 2 para 0 tratamento solarizado, às $15: 00$ horas, foram 2,5 a $4^{\circ} \mathrm{C}$ maiores dentro da casa de vegetação que na área externa (Tabela 5). Para as parcelas não solarizadas as diferenças entre os ambientes foram mais expressivas $\left(4-5^{\circ} \mathrm{C}\right)$ tanto para as temperaturas médias quanto para as máximas nas duas profundidades. As temperaturas às 8:00 horas para todos os tratamentos, em ambas as profundidades, 
foram sempre maiores dentro da casa de vegetação. As temperaturas médias e máximas obtidas neste experimento foram um pouco menores que no anterior $\left(2-3^{\circ} \mathrm{C}\right)$.

Nestes experimentos, as temperaturas máximas obtidas às 15:00 horas dentro da casa de vegetação foram um pouco superiores ( 1 a $4{ }^{\circ} \mathrm{C}$ ) às determinadas na área extema, embora as temperaturas médias tenham sido semelhantes. As principais diferenças entre os ambientes foram as temperaturas às 8:00 horas, sempre superiores dentro da casa de vegetação $\left(2-3^{\circ} \mathrm{C}\right)$, e as temperaturas das parcelas não solarizadas, que se mantiveram, em média, 2,5 a $6^{\circ} \mathrm{C}$ maiores neste ambiente.

Tabela 5. Temperaturas médias e máximas do solo obtidas às 8:00 e 15:00 horas, na casa de vegetação e na área externa, a 10 e a $20 \mathrm{~cm}$ de profundidade, nos experimentos, $1^{1}$ e $2^{2}$. Piracicaba, SP.

\begin{tabular}{|c|c|c|c|c|c|c|c|c|c|}
\hline & & \multicolumn{8}{|c|}{ Profundidade } \\
\hline & & \multicolumn{4}{|c|}{$10 \mathrm{~cm}$} & \multicolumn{4}{|c|}{$20 \mathrm{~cm}$} \\
\hline \multirow{2}{*}{\multicolumn{2}{|c|}{$\begin{array}{l}\text { Experimentol Aml } \\
\text { Horário }\end{array}$}} & \multicolumn{2}{|c|}{ Solo solarizado } & \multicolumn{2}{|c|}{$\begin{array}{l}\text { Solo não } \\
\text { solarizado }\end{array}$} & \multicolumn{2}{|c|}{$\begin{array}{c}\text { Solo } \\
\text { solarizado }\end{array}$} & \multicolumn{2}{|c|}{$\begin{array}{l}\text { Solo não } \\
\text { solarizado }\end{array}$} \\
\hline & & $T$ méd $^{3}$ & $T$ máx ${ }^{4}$ & $T$ méd & $T$ máx & $T$ méd & $T$ máx & $T$ méd & T máx \\
\hline \multicolumn{10}{|c|}{ Experimento 1} \\
\hline \multirow[t]{2}{*}{$15: 00 h$} & Casa Vegetação & 45,6 & 55,4 & 41,4 & 45,5 & 40,8 & 47,2 & 37,2 & 41,0 \\
\hline & Área externa & 45,3 & 52,0 & 35,6 & 41,2 & 39,7 & 43,4 & 31,4 & 33,1 \\
\hline \multirow[t]{2}{*}{$8: 00 \mathrm{~h}$} & Casa Vegetação & 36,0 & 39,4 & 33,0 & 36,0 & 37,9 & 41,3 & 34,1 & 37,4 \\
\hline & Área externa & 33,2 & 37,2 & 27,0 & 30,2 & 35,8 & 37,4 & 29,1 & 31,4 \\
\hline \multicolumn{10}{|c|}{ Experimento 2} \\
\hline \multirow[t]{2}{*}{$15: 00 \mathrm{~h}$} & Casa Vegetação & 43,4 & 52,1 & 37,7 & 44,0 & 39,4 & 44,6 & 35,0 & 38,6 \\
\hline & Área externa & 41,0 & 47,4 & 32,1 & 38,5 & 36,9 & 42,6 & 29,0 & 32,0 \\
\hline \multirow[t]{2}{*}{$8: 00 \mathrm{~h}$} & Casa Vegetação & 34,4 & 38,6 & 31,1 & 35,0 & 36,4 & 40,8 & 32,4 & 35,5 \\
\hline & Área externa & 31,2 & 36,7 & 25,0 & 28,8 & 33,4 & 38,0 & 27,0 & 31,1 \\
\hline
\end{tabular}



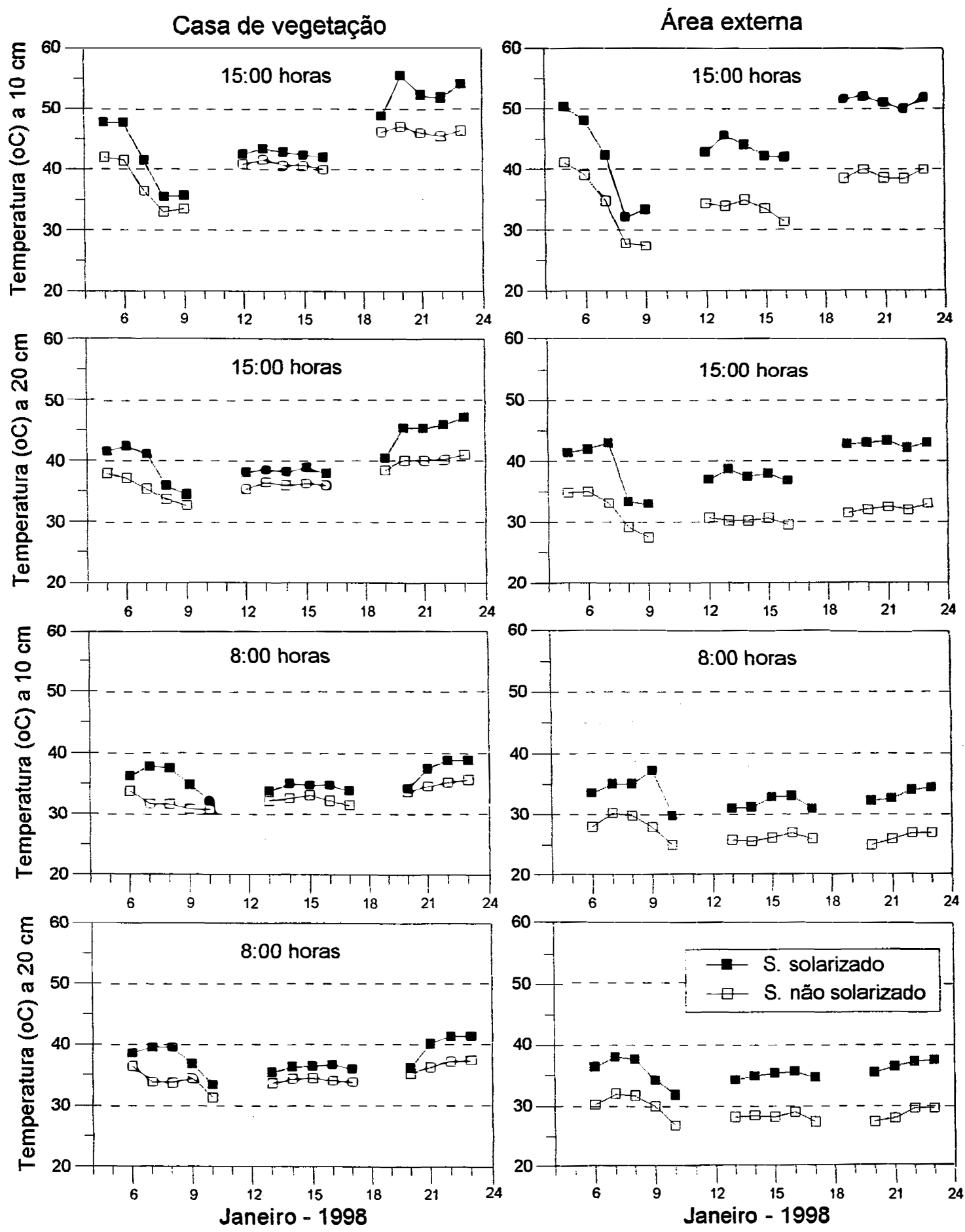

Figura 1. Temperaturas obtidas na casa de vegetação e na área externa, a 10 e a 20 $\mathrm{cm}$ de profundidade, às $15: 00$ e às $8: 00$ horas no experimento 1 . As temperaturas foram avaliadas, de segunda a sexta-feira, no período de 05 a 23 de janeiro de 1998. Piracicaba, SP. 
Casa de vegetação
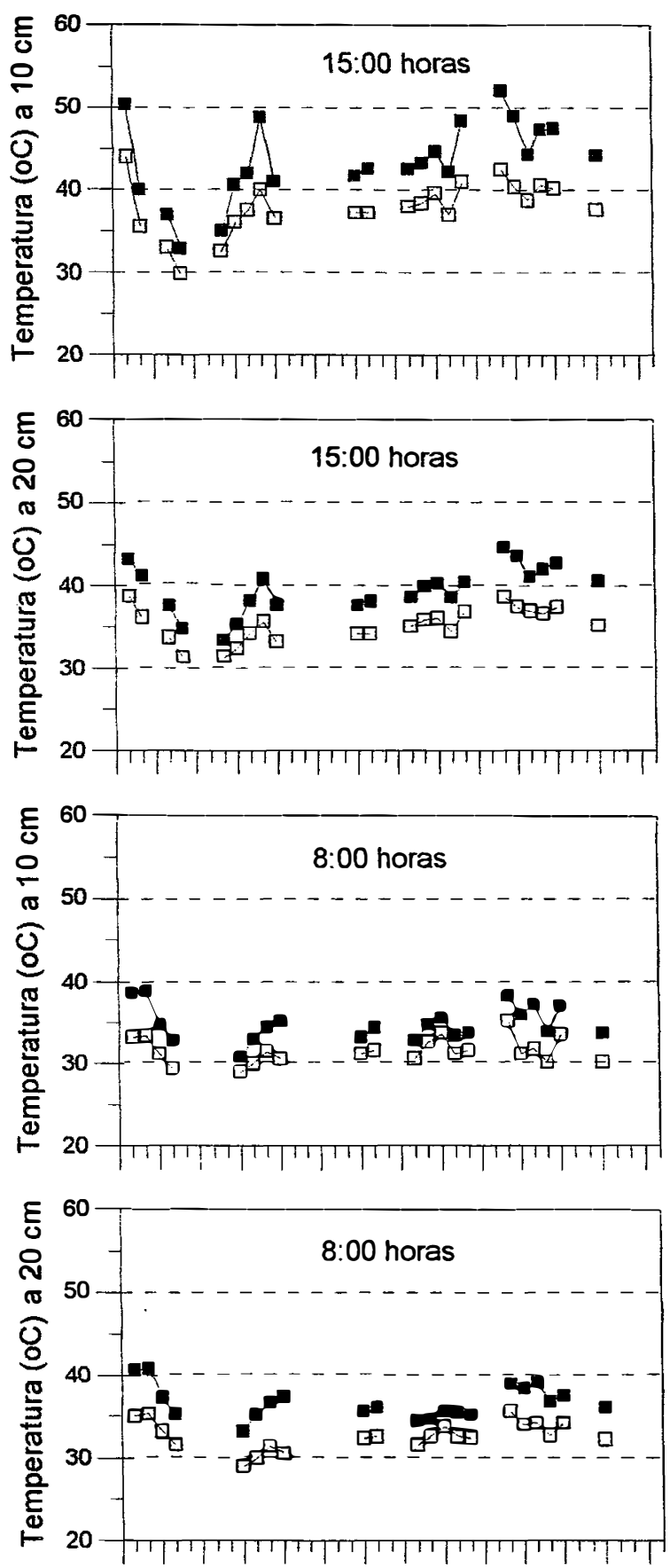

$05 / 02$ a $16 / 03 / 98$
Área externa
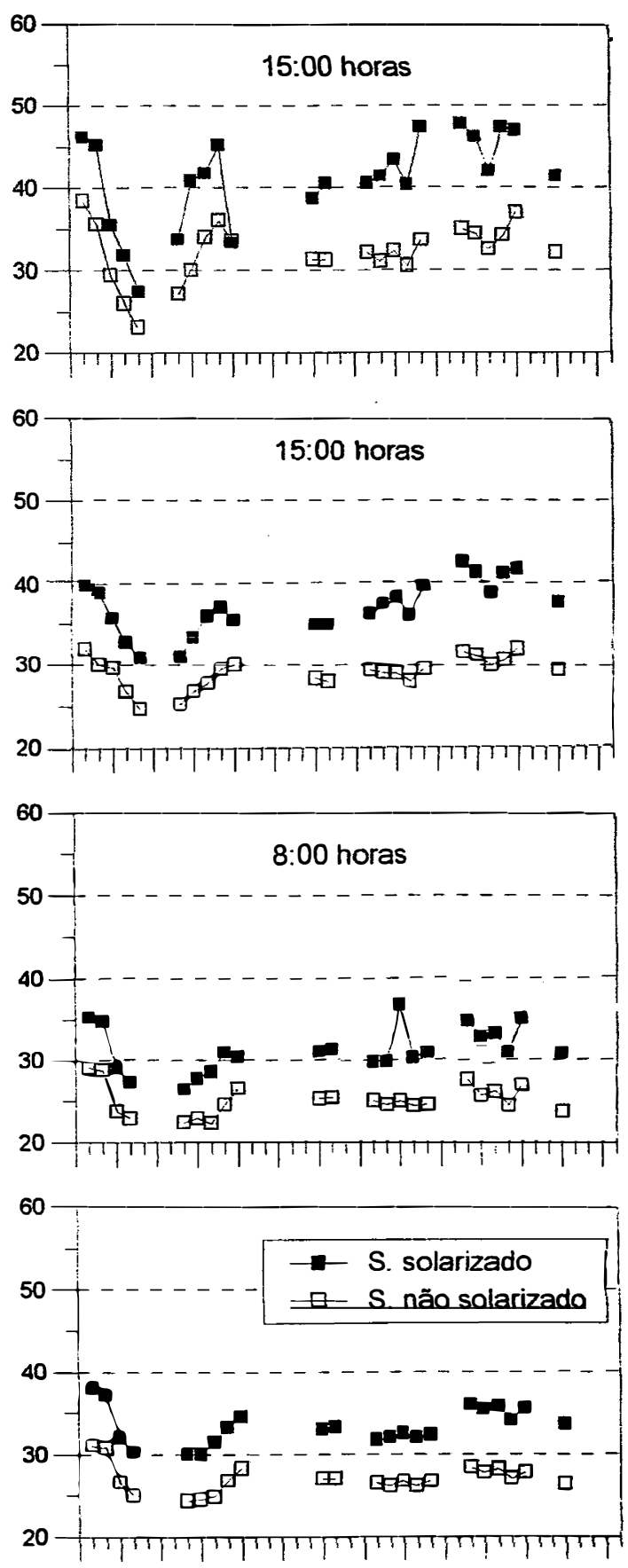

$05 / 02$ a $16 / 03 / 98$

Figura 2. Temperaturas obtidas dentro da casa de vegetação e na área externa a 10 e a $20 \mathrm{~cm}$ de profundidade, às $15: 00$ e às $8: 00$ horas no experimento 2 . As temperaturas foram avaliadas, de segunda a sexta-feira, no período 05 de fevereiro a 16 de março de 1998. Piracicaba, SP. 


\subsubsection{Viabilidade de Pythium aphanidermatum}

As médias de porcentagem de tombamento dos tratamentos referentes aos fatores: ambiente, solarização, profundidade e período, e as interações entre os fatores para os experimentos 1 e 2 , bem como a significância destes fatores e interações (Probabilidade de $\mathrm{F}<0,05$ ) encontram-se na Tabela 6 e nas Figuras 3 a 5.

Para o experimento 1 observa-se que houve diferença entre os ambientes sendo obtida redução na viabilidade de $P$. aphanidermatum dentro da casa de vegetação, com ou sem solarização. $O$ tratamento solarizado também reduziu significativamente a viabilidade do patógeno em ambos os ambientes. Não houve interação entre os tratamentos solarizados dentro e fora da casa de vegetação, indicando que o controle foi semelhante em ambos os ambientes (Figura 3). Ocorreram diferenças significativas entre as médias obtidas nas diferentes profundidades. $\mathrm{Na}$ Figura 4 observa-se que estas diferenças ocorreram porque no tratamento solarizado, na área externa, o patógeno não perdeu a viabilidade a $20 \mathrm{~cm}$ de profundidade, apresentando $74 \%$ de tombamento. Não foram detectadas diferenças significativas entre os tratamentos por 20,30 e 40 dias, dentro e fora da casa de vegetação. $\mathrm{Na}$ Figura 5 observa-se que aos 20 dias, no tratamento não solarizado na casa de vegetação o patógeno apresentou baixa viabilidade, que não se repetiu nos períodos seguintes. Este fato pode ser devido a variações na amostragem, já que não se repetiu nos experimentos seguintes.

No experimento 2 (Tabela 6) ocorreu significativa redução na incidência de tombamento dentro da casa de vegetação e nos tratamentos solarizados. Verificou-se interação significativa entre solarização e ambiente, ocorrendo redução na viabilidade de $P$. aphanidermatum apenas no tratamento solarizado dentro da casa de vegetação (Figura 3). Houve diferença significativa entre os períodos, podendo-se observar na Figura 5 que o patógeno apresentou menor viabilidade no tratamento solarizado efetuado na casa de vegetação, sendo esta mais intensa após 40 dias de tratamento. Não houve efeito da profundidade indicando que os tratamentos apresentaram comportamento semelhante em ambas as profundidades. 
Tabela 6. Fatores, tratamentos e médias da viabilidade de Pythium aphanidermatum, avaliada pela porcentagem de tombamento de plântulas de pepino, nos experimentos $1^{1}$ e $2^{2}$. Piracicaba, SP.

\begin{tabular}{|c|c|c|c|c|c|}
\hline \multirow{3}{*}{ Fatores } & \multirow{3}{*}{ Tratamentos } & \multicolumn{4}{|c|}{$\%$ Tombamento } \\
\hline & & \multicolumn{2}{|c|}{ Experimento 1} & \multicolumn{2}{|c|}{ Experimento 2} \\
\hline & & Médias & Prob. $<F$ & Médias & Prob. $<F$ \\
\hline \multirow[t]{2}{*}{ Ambiente } & Casa Vegetação & 23,6 & $0,0010^{3}$ & 59,1 & $0,0001^{3}$ \\
\hline & Área Externa & 68,3 & & 80,8 & \\
\hline \multirow[t]{2}{*}{ Solarização } & Solo solarizado & 26,8 & $0,0027^{3}$ & 55,0 & $0,0001^{3}$ \\
\hline & Solo não solarizado & 65,1 & & 84,9 & \\
\hline Ambiente $\times$ solarização & & - & 0,3198 & - & $0,0001^{3}$ \\
\hline \multirow[t]{2}{*}{ Profundidade } & $10 \mathrm{~cm}$ & 31,9 & $0,0148^{3}$ & 67,0 & 0,0800 \\
\hline & $20 \mathrm{~cm}$ & 60,1 & & 72,8 & \\
\hline Ambiente $x$ profundidade & & - & 0,4221 & - & 0,2391 \\
\hline $\begin{array}{l}\text { Solarização x } \\
\text { profundidade }\end{array}$ & & - & 0,7717 & - & 0,2340 \\
\hline \multirow[t]{3}{*}{ Período } & 20 dias & 37,5 & 0,4312 & 68,8 & $0,0181^{3}$ \\
\hline & 30 dias & 52,8 & & 76,9 & \\
\hline & 40 dias & 47,6 & & 64,1 & \\
\hline Ambiente $\times$ período & & - & 0,1678 & - & 0,6446 \\
\hline Solarização x período & & - & 0,1572 & - & 0,2040 \\
\hline Profundidade $\mathrm{x}$ período & & - & 0,8215 & - & 0,8668 \\
\hline
\end{tabular}

Efetuado no período de 18/12/1997 a 26/01/1998

2 Efetuado no período de 05/02 a 16/03/1998.

${ }^{3}$ Probabilidade de $\mathrm{F}<0,05$ considerada significativa. 
Experimento 1

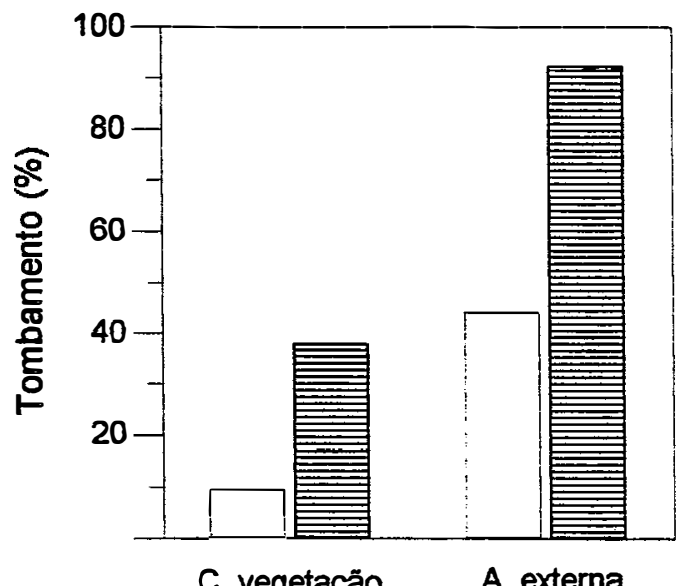

Experimento 2

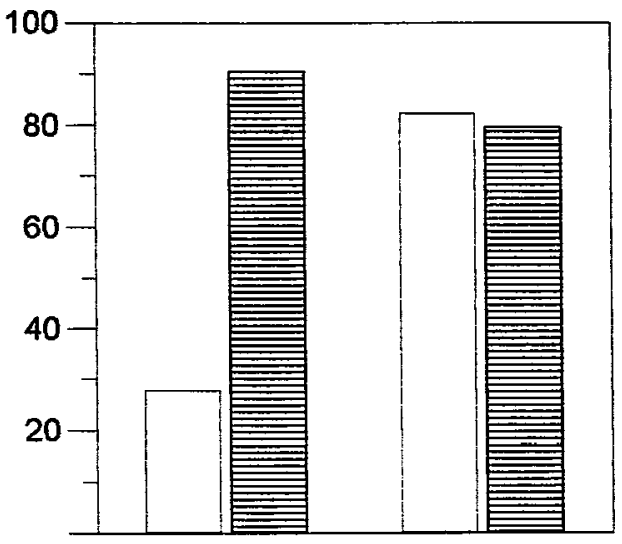

C. vegetação

A. externa

\section{S. solarizado}

S. não solarizado

Figura 3. Médias da viabilidade de Pythium aphanidermatum, avaliada pela porcentagem de tombamento, dos tratamentos solarizados e não solarizados, dentro da casa de vegetação e na área externa, dos experimentos 1 e 2 . Piracicaba, SP.

Casa de vegetação

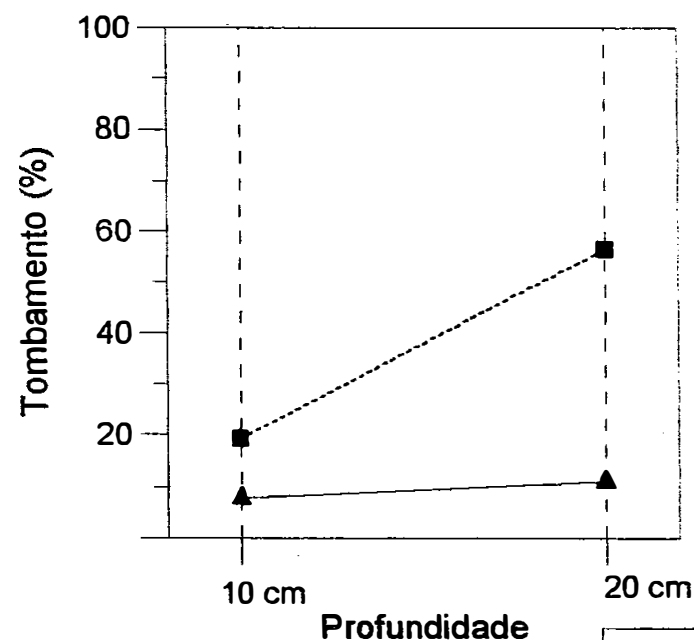

$\neg$ S. solarizado

S. não solarizado
Área externa

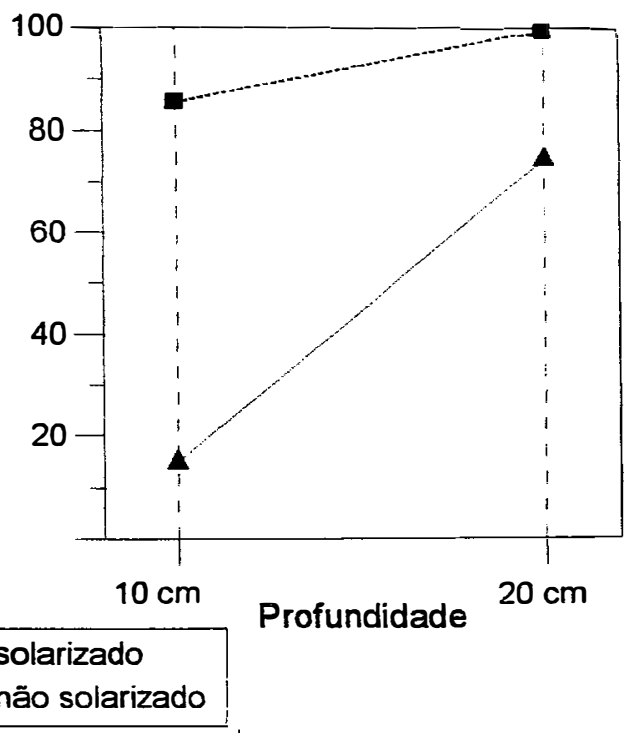

Figura 4. Médias da viabilidade de Pythium aphanidermatum no experimento 1 avaliada pela porcentagem de tombamento, com os tratamentos solarizados e não solarizados, a 10 e a $20 \mathrm{~cm}$ de profundidade, dentro da casa de vegetação e na área externa. Piracicaba, SP. 
Casa de vegetação

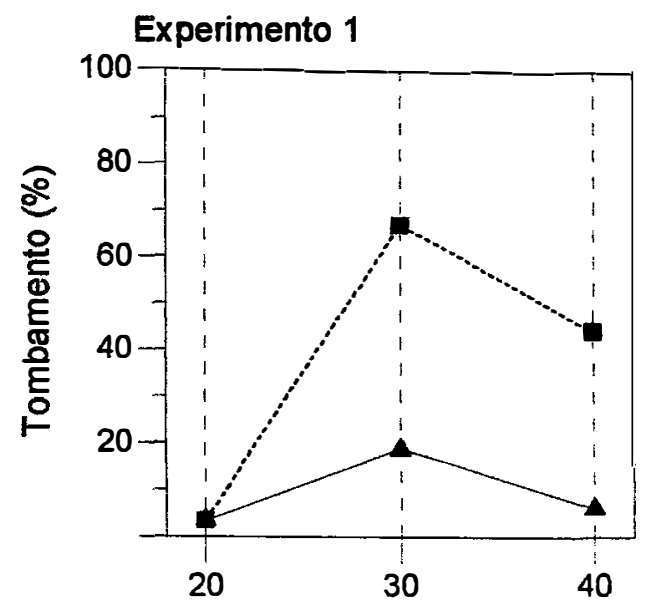

Experimento 2

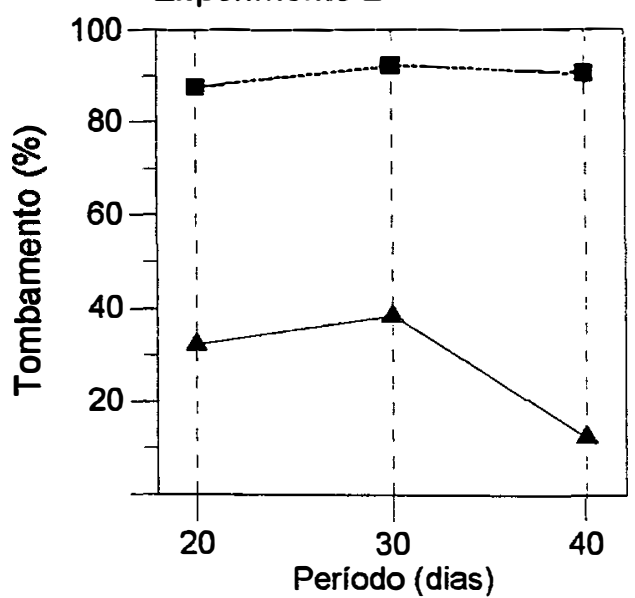

Área externa

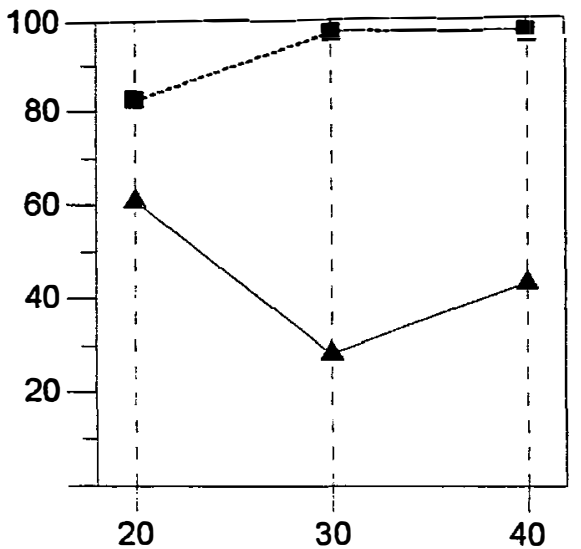

100

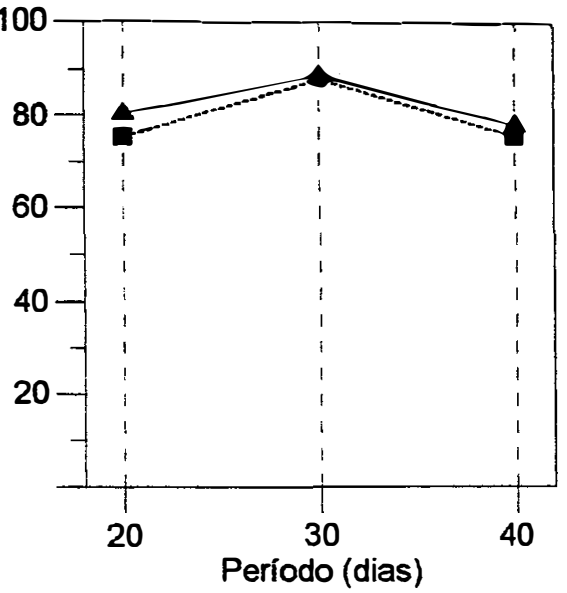

S. solarizado

S. não solarizado

Figura 5. Médias da viabilidade de Pythium aphanidermatum nos experimentos 1 e 2 avaliada pela porcentagem de tombamento, com os tratamentos solarizados e não solarizados dentro da casa de vegetação e na área externa, aos 20 , 30 e 40 dias após o seu início. Piracicaba, SP. 


\subsubsection{Viabilidade de Rhizoctonia solani}

As médias dos tratamentos dos fatores: ambiente, solarização, profundidade e período, e as interações entre os fatores para os experimentos 1 e 2 , bem como a significância destes fatores e interações (Probabilidade de $F<0,05$ ) encontram-se na Tabela 7 e nas Figuras 6 e 7.

Observa-se na Tabela 7 que para o primeiro experimento, houve diferença significativa entre tratamentos dentro dos fatores ambiente, solarização, e interação significativa entre estes fatores, que pode ser observada na Figura 7. A interação ocorreu porque o patógeno perdeu a viabilidade dentro da casa de vegetação, inclusive na área não solarizada (Figura 7) enquanto na área não solarizada externa apenas pequena parte da viabilidade foi perdida. A solarização controlou eficientemente o patógeno em ambos os ambientes. Observa-se na Figura 6 que, na casa de vegetação, o patógeno foi erradicado 20 dias após o início do experimento, ao passo que na área extema, embora tenha perdido drasticamente a viabilidade, foi erradicado após 40 dias de tratamento. Também houve controle do patógeno, após 40 dias, na área não solarizada dentro da casa de vegetação. A redução na viabilidade do patógeno foi proporcional em ambas as profundidades, não havendo interação entre profundidade e os demais fatores avaliados.

No segundo experimento o patógeno também perdeu a viabilidade nos dois tratamentos da casa de vegetação, a viabilidade também foi significativamente menor no tratamento solarizado do fator solarização, e houve interação significativa entre estes dois fatores, que pode ser observada na Figura 7. Como no experimento anterior, mas em menor proporção, o patógeno perdeu a viabilidade no tratamento não solarizado dentro da casa de vegetação, o que não ocorreu na área extema (Figura 7). Os tratamentos apresentaram comportamento semelhante nas duas profundidades. Houve diferença significativa entre os períodos avaliados, com a perda da viabilidade do patógeno ao longo do tempo. Como no experimento anterior, observa-se que ocorreu inativação do patógeno aos 20 dias após o início do experimento dentro da casa de vegetação e aos 40 dias na área extema (Figura 7). No tratamento não solarizado da casa de vegetação, a redução na viabilidade do patógeno foi mais lenta que no experimento anterior. 
Tabela 7. Fatores, tratamentos e médias da viabilidade de Rhizoctonia solani, avaliada pela porcentagem de sementes com micélio viável do patógeno, nos experimentos $1^{1}$ e $2^{2}$.

\begin{tabular}{|c|c|c|c|c|c|}
\hline \multirow{3}{*}{ Fatores } & \multirow{3}{*}{ Tratamentos } & \multicolumn{4}{|c|}{ Rhizoctonia solani (\%) } \\
\hline & & \multicolumn{2}{|c|}{ Experimento 1} & \multicolumn{2}{|c|}{ Experimento 2} \\
\hline & & Médias & Prob. $<F$ & Médias & Prob. $<F$ \\
\hline \multirow[t]{2}{*}{ Ambiente } & Casa Vegetação & 3,1 & $0,0001^{3}$ & 17,2 & $0,0003^{3}$ \\
\hline & Área Externa & 38,0 & & 52,1 & \\
\hline \multirow[t]{2}{*}{ Solarização } & Solo solarizado & 1,5 & $0,0001^{3}$ & 5,6 & $0,0001^{3}$ \\
\hline & Solo não solarizado & 39,9 & & 63,6 & \\
\hline $\begin{array}{l}\text { Ambiente } \\
\text { solarização }\end{array}$ & $x$ & - & $0,0001^{3}$ & - & $0,0032^{3}$ \\
\hline \multirow[t]{2}{*}{ Profundidade } & $10 \mathrm{~cm}$ & 17,6 & 0,0699 & 32,0 & 0,4060 \\
\hline & $20 \mathrm{~cm}$ & 23,6 & & 37,3 & \\
\hline $\begin{array}{l}\text { Ambiente } \\
\text { profundidade }\end{array}$ & $x$ & - & 0,2178 & - & 0,6905 \\
\hline $\begin{array}{l}\text { Solarização x } \\
\text { profundidade }\end{array}$ & & - & 0,1985 & - & 0,8457 \\
\hline \multirow[t]{3}{*}{ Período } & 20 dias & 27,1 & $0,0221^{3}$ & 44,3 & 0,0678 \\
\hline & 30 dias & 19,9 & & 35,3 & \\
\hline & 40 dias & 14,8 & & 24,7 & \\
\hline \multicolumn{2}{|c|}{ Ambiente $x$ período } & - & 0,4596 & - & 0,6267 \\
\hline \multicolumn{2}{|c|}{ Solarização x período } & - & 0,0693 & - & 0,4787 \\
\hline \multicolumn{2}{|l|}{$\begin{array}{l}\text { Profundidade } x \\
\text { período }\end{array}$} & - & 0,5306 & - & 0,6911 \\
\hline
\end{tabular}


Casa de vegetação
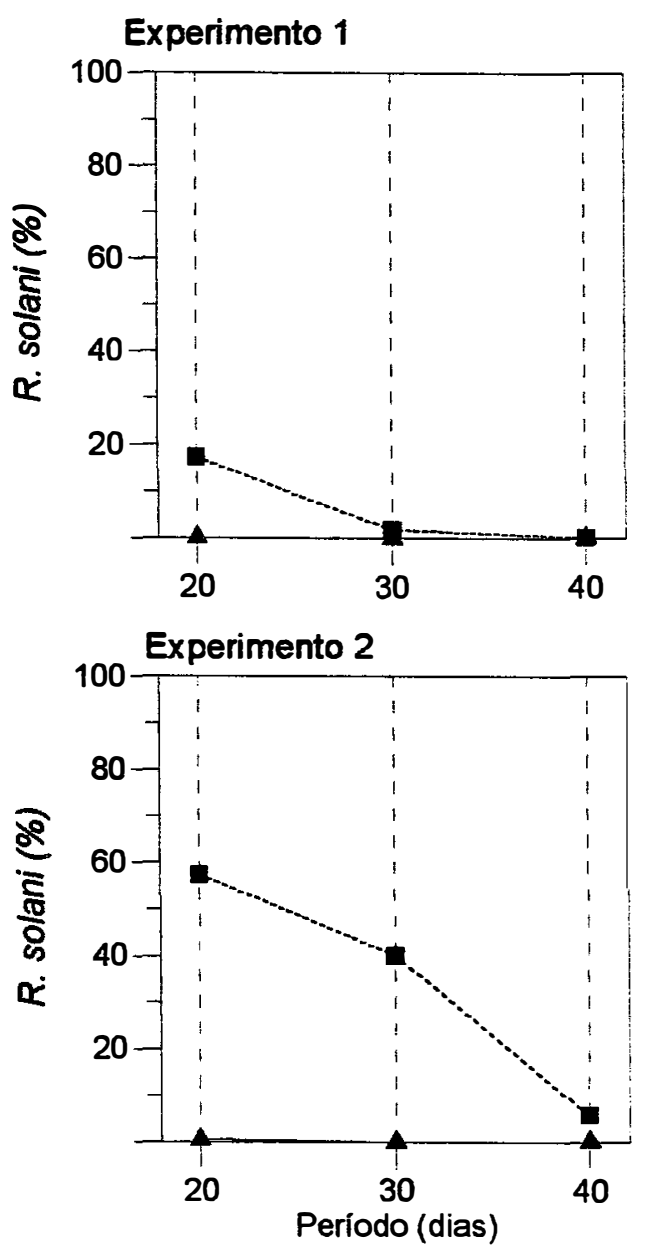

Área externa
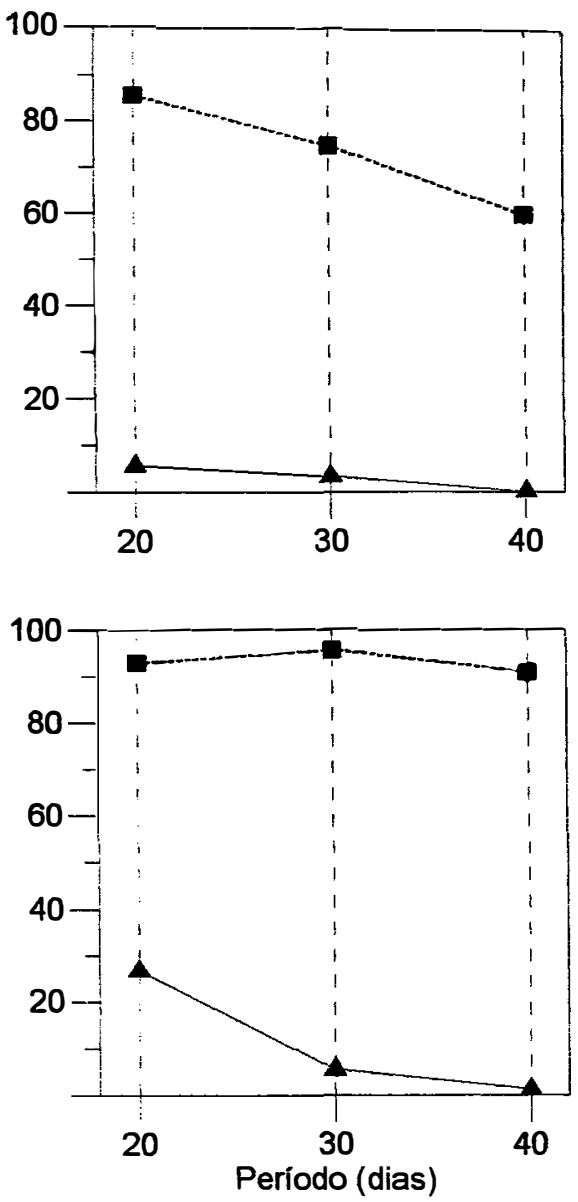

\section{- S. solarizado \\ S. nāo solarizado}

Figura 6. Médias da viabilidade de Rhizoctonia solani, avaliada pela porcentagem de sementes com micélio viável do patógeno, dos tratamentos solarizados e não solarizados, aos 20,30 e 40 dias após o início dos experimentos 1 efetuado no período de 18/12/97 a 26/01/98 e 2, realizado no período de 05/02 a 16/03/98, dentro da casa de vegetação e na área externa. Piracicaba, SP. 


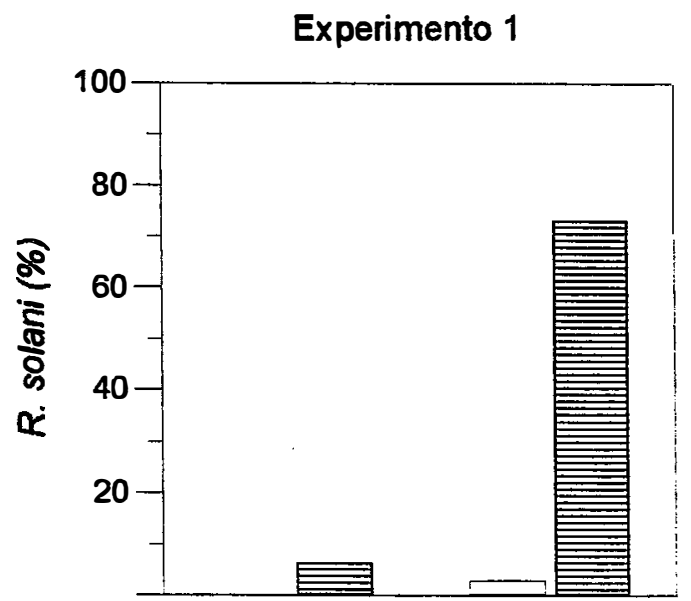

C. vegetação

A. externa
Experimento 2

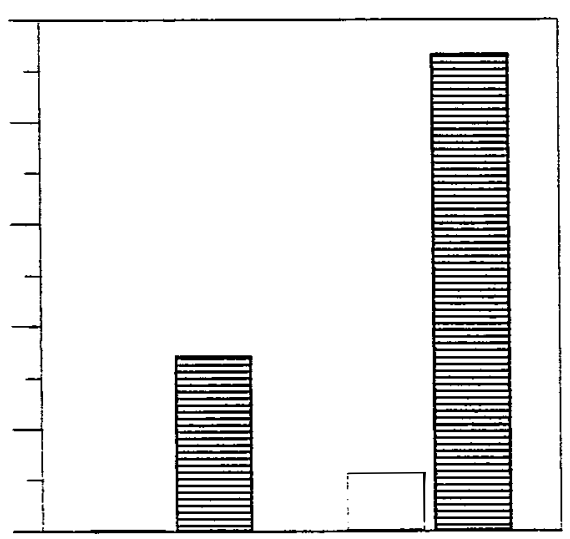

C. vegetaçāo

A. externa

\section{S. solarizado \\ S. nāo solarizado}

Figura 7. Médias da viabilidade de Rhizoctonia solani, avaliada pela porcentagem de sementes com micélio viável do patógeno, dos tratamentos solarizados e não solarizados dos experimentos 1 , efetuado no período de 18/12/97 a 26/01/98 e 2, realizado no período de 05/02 a 16/03/98, dentro da casa de vegetação e na área externa. Piracicaba, SP.

\subsubsection{Experimentos 3, 4 e 5}

\subsubsection{Temperaturas}

As temperaturas obtidas nos experimentos 3,4 e 5, estão na Tabela 8. Para o experimento 3 as temperaturas médias e máximas das parcelas solarizadas dentro e fora da casa de vegetação foram semelhantes. Nos experimentos 4 e 5 , as temperaturas médias dos tratamentos solarizados foram superiores na área extema, sendo as máximas semelhantes. Para todos os experimentos as temperaturas obtidas nas parcelas não solarizadas foram sempre superiores dentro da casa de vegetação, 
em ambas profundidades. As temperaturas médias do experimento 4 foram menores que as observadas no experimento 5.

Tabela 8. Temperaturas médias e máximas do solo obtidas às 15:00 horas na casa de vegetação e na área externa, a 10 e a $20 \mathrm{~cm}$ de profundidade, nos experimentos, $3^{1}, 4^{2}$ e $5^{3}$. Piracicaba, SP.

\begin{tabular}{|c|c|c|c|c|c|c|c|c|}
\hline \multirow{4}{*}{$\begin{array}{l}\text { Experimento/ } \\
\text { Ambiente }\end{array}$} & \multicolumn{8}{|c|}{ Profundidade } \\
\hline & \multicolumn{4}{|c|}{$10 \mathrm{~cm}$} & \multicolumn{4}{|c|}{$20 \mathrm{~cm}$} \\
\hline & \multicolumn{2}{|c|}{ Solo solarizado } & \multicolumn{2}{|c|}{$\begin{array}{l}\text { Solo não } \\
\text { solarizado }\end{array}$} & \multicolumn{2}{|c|}{ Solo solarizado } & \multicolumn{2}{|c|}{$\begin{array}{l}\text { Solo não } \\
\text { solarizado }\end{array}$} \\
\hline & $T$ méd ${ }^{4}$ & $T$ máx ${ }^{5}$ & T méd & $T$ máx & T méd & T máx & T méd & $T$ máx \\
\hline \multicolumn{9}{|l|}{ Experimento 3} \\
\hline Casa Vegetação & 42,5 & 49,9 & 36,1 & 41,5 & 37,3 & 40,6 & 32,5 & 34,9 \\
\hline Área externa & 42,0 & 48,5 & 31,9 & 38,3 & 36,7 & 42,6 & 29,2 & 31,4 \\
\hline \multicolumn{9}{|l|}{ Experimento 4} \\
\hline Casa Vegetação & 40,0 & 49,3 & 34,9 & 40,5 & 36,2 & 41,2 & 31,7 & 35,2 \\
\hline Área externa & 42,5 & 49,3 & 31,9 & 38,1 & 37,2 & 41,5 & 29,2 & 33,1 \\
\hline \multicolumn{9}{|l|}{ Experimento 5} \\
\hline Casa Vegetação & 41,1 & 49,3 & 35,9 & 40,5 & 37,8 & 41,2 & 32,4 & 35,2 \\
\hline Área externa & 44,9 & 49,3 & 33,5 & 38,1 & 39,2 & 41,5 & 30,2 & 33,1 \\
\hline $\begin{array}{l}{ }^{1} \text { Temperaturas av } \\
2 \text { Temperaturas av } \\
{ }^{3} \text { Temperaturas av } \\
{ }^{4} \text { Temperatura mé } \\
{ }^{5} \text { Temperatura má }\end{array}$ & $\begin{array}{l}\text { iadas no } \\
\text { iadas no } \\
\text { iadas no } \\
\text { a } \\
\text { na }\end{array}$ & $\begin{array}{l}\text { período } \\
\text { período } \\
\text { período }\end{array}$ & $\begin{array}{l}\text { e } 30 / 11 / \\
\text { le } 29 / 01 \\
\text { le } 03 / 03\end{array}$ & $\begin{array}{l}\text { a 28/1 } \\
10 / 03 / 9 \\
01 / 04 / 9\end{array}$ & & & & \\
\hline
\end{tabular}

\subsubsection{Viabilidade de Pythium aphanidermatum}

As médias com a viabilidade de Pythium aphanidermatum dos tratamentos dos fatores ambiente, solarização, e profundidade e a significância (Teste F) para os experimentos de números 3 e 5 em cada período avaliado (15, 30 e 45 dias) encontram-se na Tabela 10. Os períodos avaliados foram comparados por meio de 
teste de Wilks-Lambda e $s$ médias e o valor do teste $F$ para estes três experimentos encontram-se na Tabela 10.

No experimento 3 , aos 15 dias foram verificadas diferenças para os fatores profundidade $(10$ e $20 \mathrm{~cm}$ ) e a interação entre solarização e profundidade. Para o tempo de 45 dias foram observadas diferenças entre ambientes, solarização, profundidade e interação entre solarização e profundidade. As interações entre profundidade e solarização podem ser observadas na Figura 8. Verificou-se redução na viabilidade de $P$. aphanidermatum nos tratamentos solarizados dentro da casa de vegetação a $10 \mathrm{~cm}$ de profundidade, mas a solarização a $20 \mathrm{~cm}$ favoreceu o patógeno. Após 45 dias, ocorreu redução na viabilidade do patógeno nas parcelas não solarizadas da área externa (Figura 8 ), que pode ser resultante de antagonismo no solo. As médias dos períodos avaliados (Figura 10 ) diferiram entre si e houve interação significativa entre periodos e profundidade, indicando que o comportamento dos fatores durante o experimento foi diferente em cada profundidade. Os resultados indicam que não ocorreu controle consistente de $P$. aphanidermatum em ambos os ambientes pois ocorreu redução na viabilidade do patógeno apenas a $10 \mathrm{~cm}$ de profundidade no tratamento solarizado dentro da casa de vegetação.

No experimento 5 ocorreram taxas relativamente baixas de tombamento. Provavelmente o solo infestado coletado na ESALQ-USP tenha recebido algum tipo de tratamento ou foi arado. Os testes de viabilidade realizados em casa de vegetação em Campinas, foram conduzidos em uma época com temperatura mais amena (abril), o que também pode ter reduzido o tombamento. Neste experimento foram verificadas diferenças, aos 30 dias após o seu início, entre os tratamentos dos fatores solarização e profundidade e a interação entre os mesmos foi significativa. Aos 45 dias as diferenças significativas ocorreram entre os tratamentos dos fatores ambiente, solarização, e também para a interação entre solarização e profundidade. A Figura 9 mostra que ocorreu o controle do patógeno a $10 \mathrm{~cm}$ de profundidade na área externa. Aos 45 dias ambos os tratamentos solarizados mostraram redução na viabilidade do patógeno a $10 \mathrm{~cm}$, que não ocorreu na profundidade de $20 \mathrm{~cm}$. 
Tabela 9. Médias de viabilidade de Pythium aphanidermatum, avaliada pela porcentagem de tombamento, e teste de significância (Teste $F$ ) dos períodos (15, 30 e 45 dias) avaliados e interações com os fatores ambiente, solarização e profundidade para os experimentos 3 e 5, realizados respectivamente nos períodos de 24/11/98 a 07/01/99 e 28/02 a 16/04/1999. Piracicaba, SP.

\begin{tabular}{|c|c|c|c|c|c|}
\hline \multirow[b]{2}{*}{ Fatores } & \multirow[b]{2}{*}{ Tratamentos } & \multicolumn{2}{|c|}{ Experimento 3} & \multicolumn{2}{|c|}{ Experimento 5} \\
\hline & & Médias & Prob. $>\mathrm{F}$ & Médias & Prob. $>\mathrm{F}$ \\
\hline \multirow[t]{3}{*}{ Períodos } & 15 dias & 43,9 & $0,0002^{1}$ & 19,1 & $0,0086^{1}$ \\
\hline & 30 dias & 23,1 & & 15,7 & \\
\hline & 45 dias & 26,7 & & 11,9 & \\
\hline \multirow[t]{2}{*}{ Períodos $x$ ambiente } & C. vegetação & 28,9 & 0,1840 & 18,0 & 0,2365 \\
\hline & A. externa & 33,5 & & 13,1 & \\
\hline \multirow[t]{2}{*}{ Periodos $x$ solarização } & Solo solarizado & 31,8 & 0,0583 & 13,3 & 0,5285 \\
\hline & S. não solarizado & 30,6 & & 17,9 & \\
\hline Periodos $x$ & $10 \mathrm{~cm}$ & 23,2 & $0,0448^{1}$ & 13,4 & 0,5334 \\
\hline profundidade & $20 \mathrm{~cm}$ & 39,2 & & 17,8 & \\
\hline $\begin{array}{l}\text { Periodos } \times \text { solar. } x \\
\text { profund. }\end{array}$ & & & 0,0747 & & 0,1122 \\
\hline
\end{tabular}

Teste de Wilks-Lambda, probabilidade de $\mathrm{F}>$ 0,05 considerada significativa. 


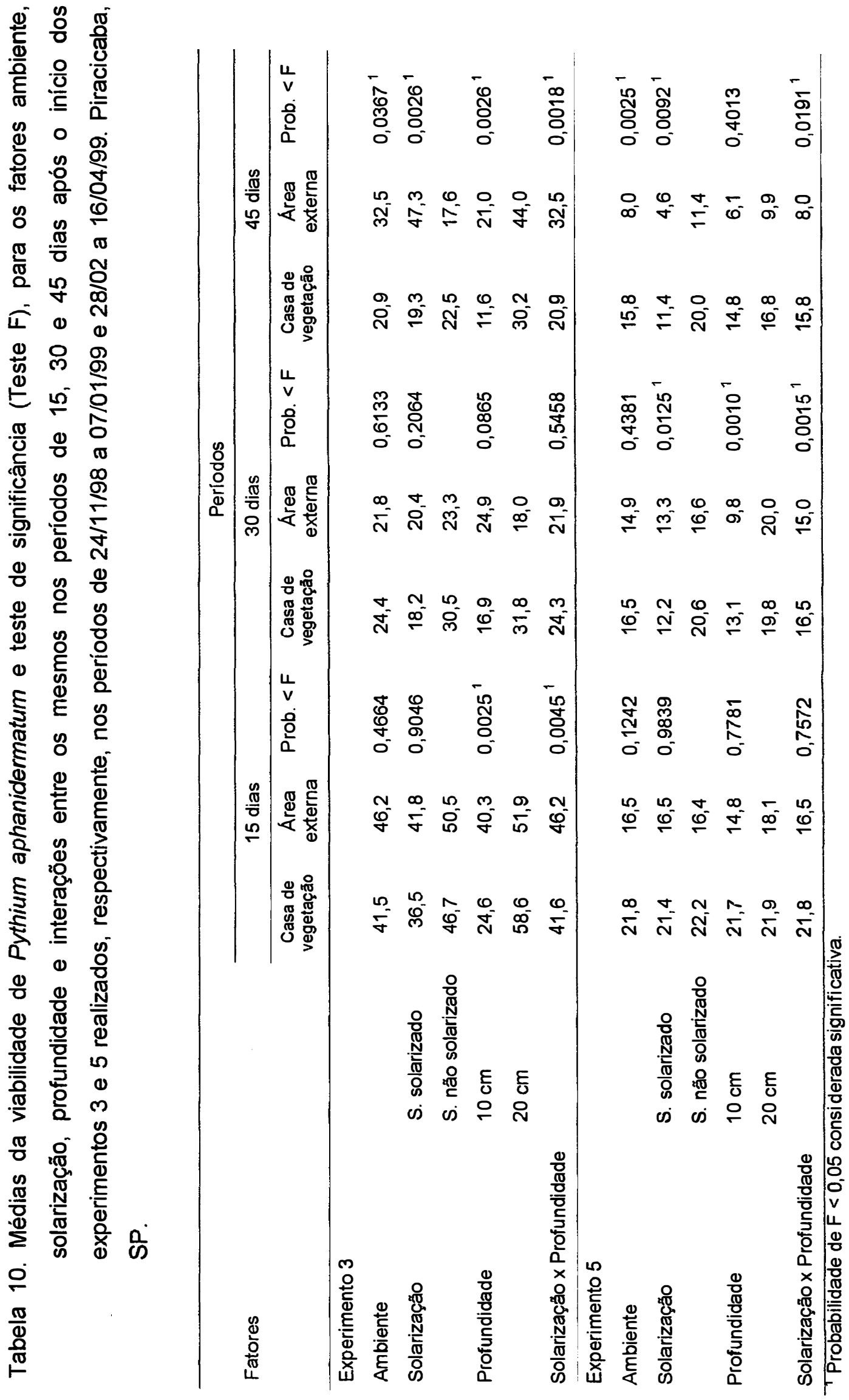



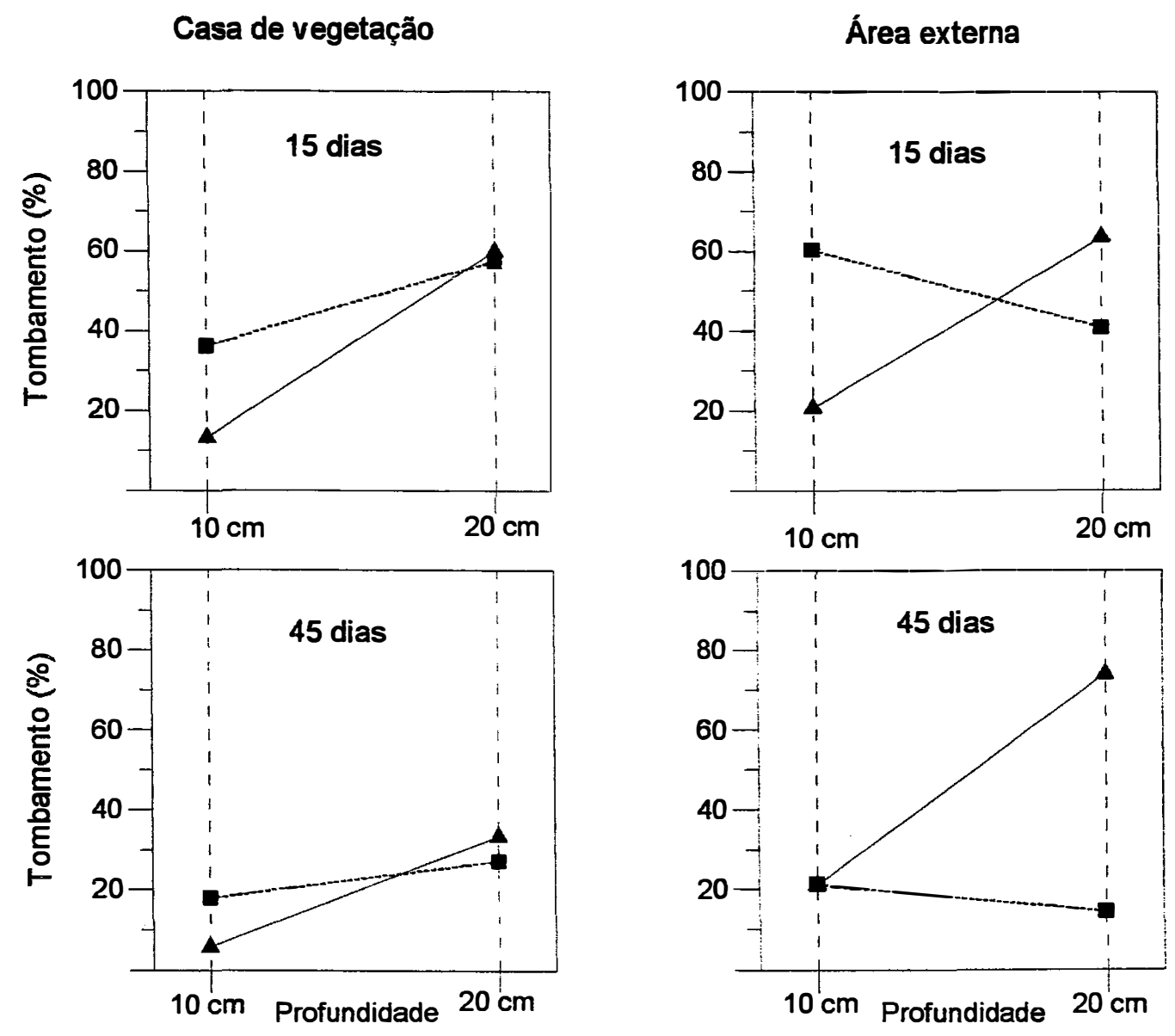

- _ S. solarizado

- S. não solarizado

Figura 8. Médias da viabilidade de Pythium aphanidermatum, avaliada pela porcentagem de tombamento, dos tratamentos solarizados e não solarizados, a 10 e a $20 \mathrm{~cm}$ de profundidade, aos 15 e aos 45 dias após o início do experimento 3 , realizado no período de 24/11/98 a 07/01/99, dentro da casa de vegetação e na área externa. Piracicaba, SP. 

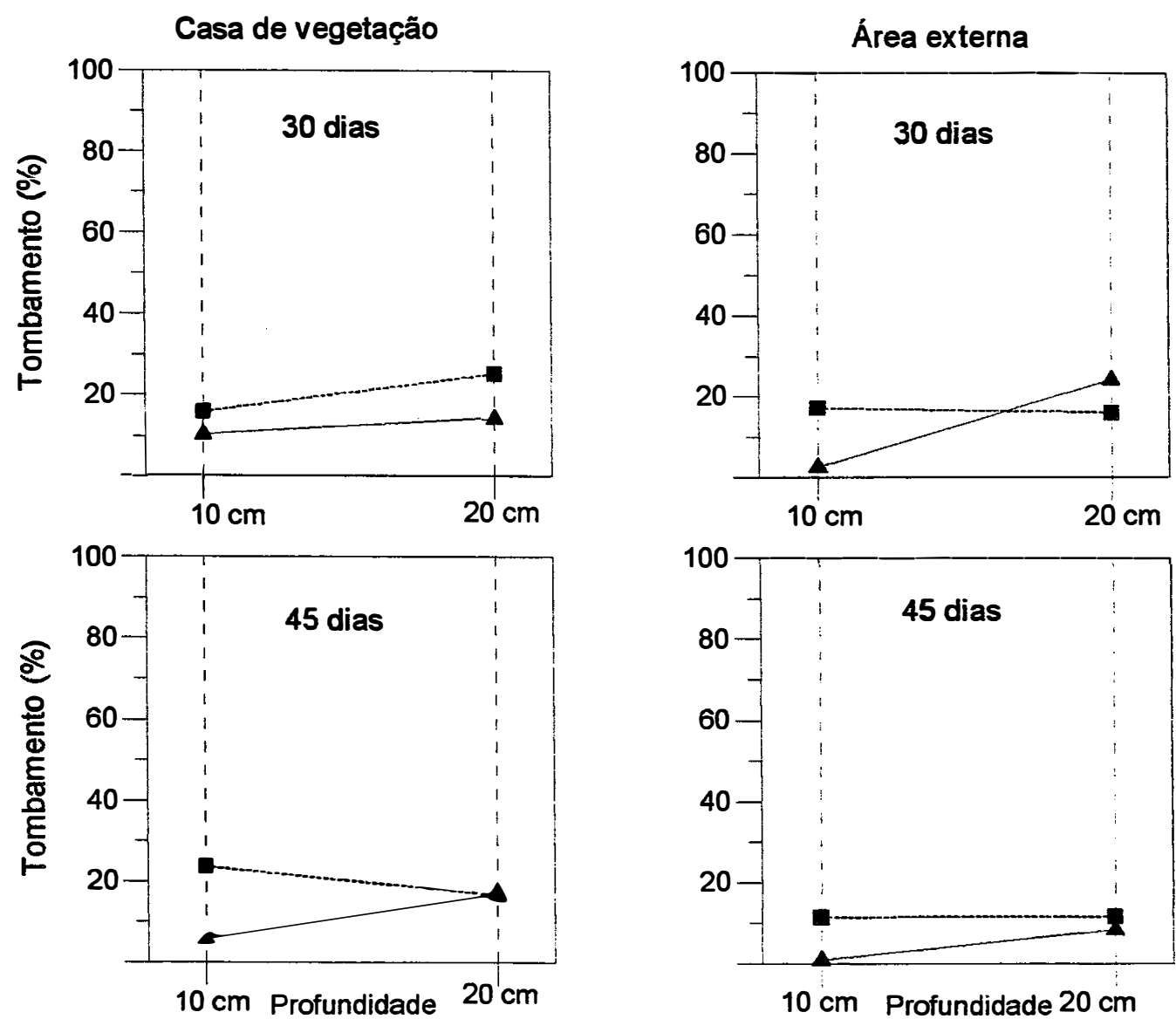

$\neg$ S. solarizado

S. não solarizado

Figura 9. Médias da viabilidade de Pythium aphanidermatum, avaliada pela porcentagem de tombamento, dos tratamentos solarizados e não solarizados, a 10 e a $20 \mathrm{~cm}$ de profundidade, observadas no experimento 5 , realizado no período de $28 / 02$ a 16/04/1999 dentro da casa de vegetação e na área externa. Piracicaba, SP. 

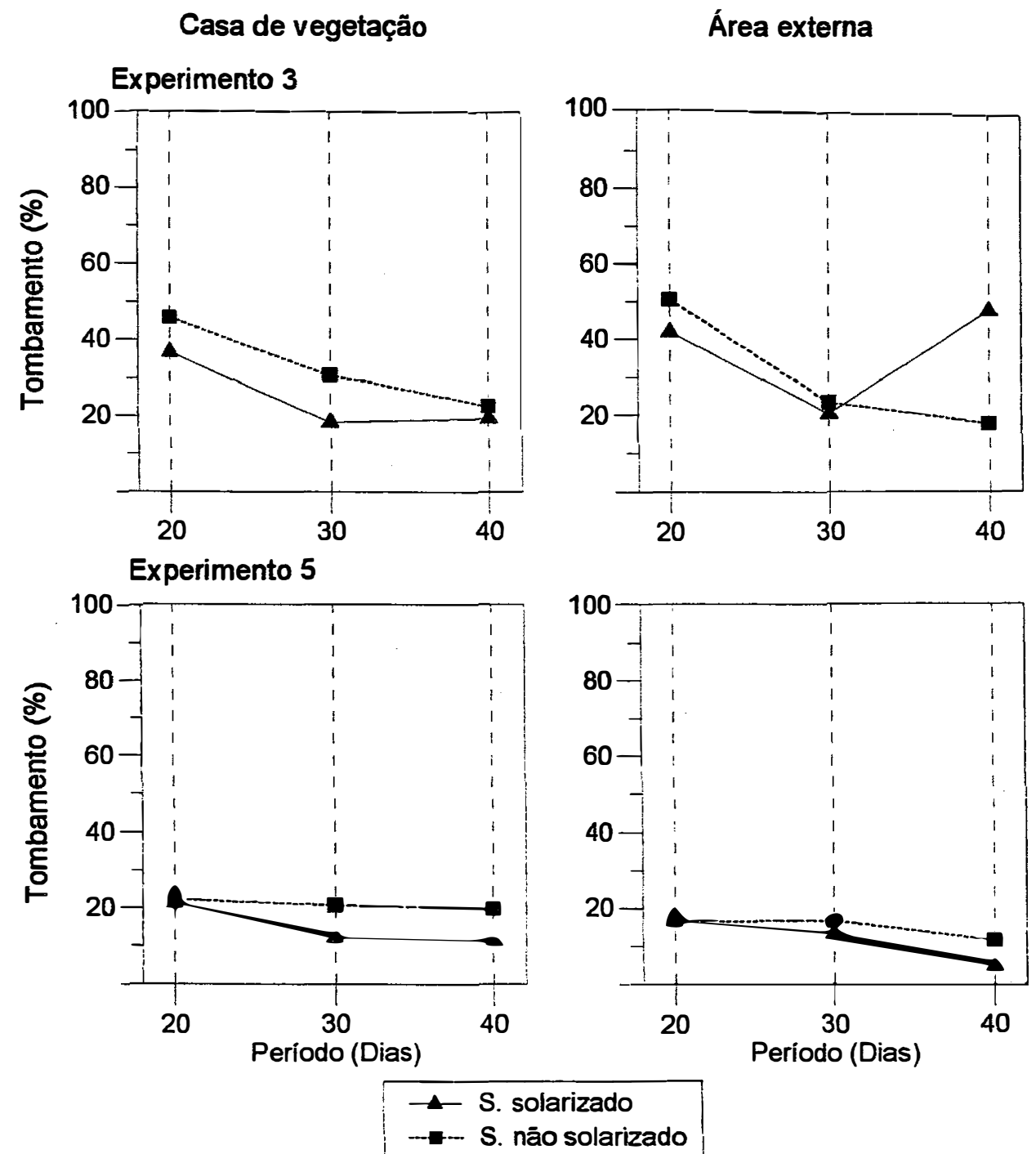

Figura 10. Médias da viabilidade de Pythium aphanidermatum, avaliada pela porcentagem de tombamento de pós-emergência, dos tratamentos solarizados e não solarizados, dos experimentos 3 e 5 realizados, respectivamente, nos períodos de 24/11/98 a 07/01/99 e 28/02 a 16/04/99, dentro da casa de vegetação e na área extema. Piracicaba, SP. 


\subsubsection{Viabilidade de Rhizoctonia solani}

No experimento 4 foram verificadas diferenças significativas entre os ambientes, dentro e fora da casa de vegetação, e entre os tratamentos envolvendo solarização, não havendo interação entre os mesmos (Tabela 12 e Figura 11). Aos 15 dias após 0 início do experimento ocorreram diferenças significativas entre as profundidades, que não se mantiveram nos demais períodos avaliados. Na figura 12 pode-se verificar que o patógeno $R$. solani foi erradicado nas parcelas solarizadas após 30 dias dentro da casa de vegetação e após 40 dias na área externa. Houve redução na viabilidade do fungo dentro da casa de vegetação, nas áreas não solarizadas, insuficiente, porém, para causar sua erradicação. Os períodos e as interações entre períodos e ambiente e períodos e solarização foram significativas (Tabela 11). As interações podem ser observadas na Figura 11, verificando-se que dentro da casa de vegetação o patógeno perdeu rapidamente a viabilidade nas parcelas não solarizadas, o que ocorreu lentamente e em menor proporção na área externa.

No experimento 5 os tratamentos solarizado e não solarizado diferiram significativamente em todos os periodos avaliados. Após 45 dias ocorreram diferenças entre as profundidades e interação entre profundidade e solarização. A Figura 11 mostra que ocorreu erradicação do patógeno após 45 dias de tratamento na área externa. Na casa de vegetação, a $20 \mathrm{~cm}$ de profundidade, o patógeno não havia perdido totalmente a viabilidade. Neste experimento também não ocorreu perda de viabilidade significativa do patógeno dentro da casa de vegetação nas parcelas não solarizadas, indicando que as temperaturas atingidas pelas mesmas (média de 35,9 e máxima de $40,5^{\circ} \mathrm{C}$ ) não foram suficientes para reduzir a viabilidade do patógeno. Ao serem comparados, os períodos apresentaram diferenças significativas e a interação entre solarização $x$ profundidade também foi significativa (Tabela 11). 
Tabela 11. Médias de viabilidade de Rhizoctonia solani, avaliada pela porcentagem de sementes com micélio viável do patógeno, e teste de significância (Teste F) dos períodos de 15, 30 e 45 dias, e interações com os fatores ambiente, solarização e profundidade para os experimentos 4 e 5 realizados, respectivamente, nos períodos de 29/01 a 11/03/99 e 28/02 a 16/04/99. Piracicaba, SP.

\begin{tabular}{|c|c|c|c|c|c|}
\hline \multirow[b]{2}{*}{ Fatores } & \multirow[b]{2}{*}{ Tratamentos } & \multicolumn{2}{|c|}{ Experimento 4} & \multicolumn{2}{|c|}{ Experimento 5} \\
\hline & & Médias & Prob. $>\mathrm{F}$ & Médias & Prob. > F \\
\hline \multirow[t]{3}{*}{ Períodos } & 15 dias & 45,3 & $0,0001^{1}$ & 40,2 & $0,0007^{1}$ \\
\hline & 30 dias & 26,6 & & 33,5 & \\
\hline & 45 dias & 14,7 & & 29,0 & \\
\hline \multirow[t]{2}{*}{ Períodos $\times$ Ambiente } & C. vegetação & 17,7 & $0,0010^{1}$ & 34,5 & 0,8449 \\
\hline & A. externa & 40,3 & & 33,9 & \\
\hline \multirow[t]{2}{*}{ Períodos $\times$ cobertura } & Solo solarizado & 5,6 & $0,0001^{1}$ & 3,2 & 0,2796 \\
\hline & S. não solarizado & 52,3 & & 65,2 & \\
\hline Períodos $\mathrm{x}$ & $10 \mathrm{~cm}$ & 25,0 & 0,5492 & 32,9 & 0,1741 \\
\hline profundidade & $20 \mathrm{~cm}$ & 32,9 & & 35,5 & \\
\hline $\begin{array}{l}\text { Períodos } x \text { solar. } x \\
\text { profundidade }\end{array}$ & & & 0,2168 & & $0,0457^{1}$ \\
\hline
\end{tabular}


(1)

을 응

总 क ष

응 ह 응

:

을 Ð

.

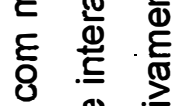



ฮ

Ф

을 은 Nㅡㄴ

ฮั

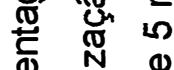

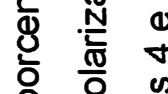

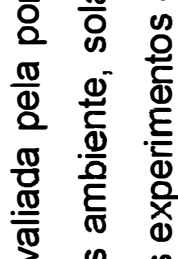

สั

হ

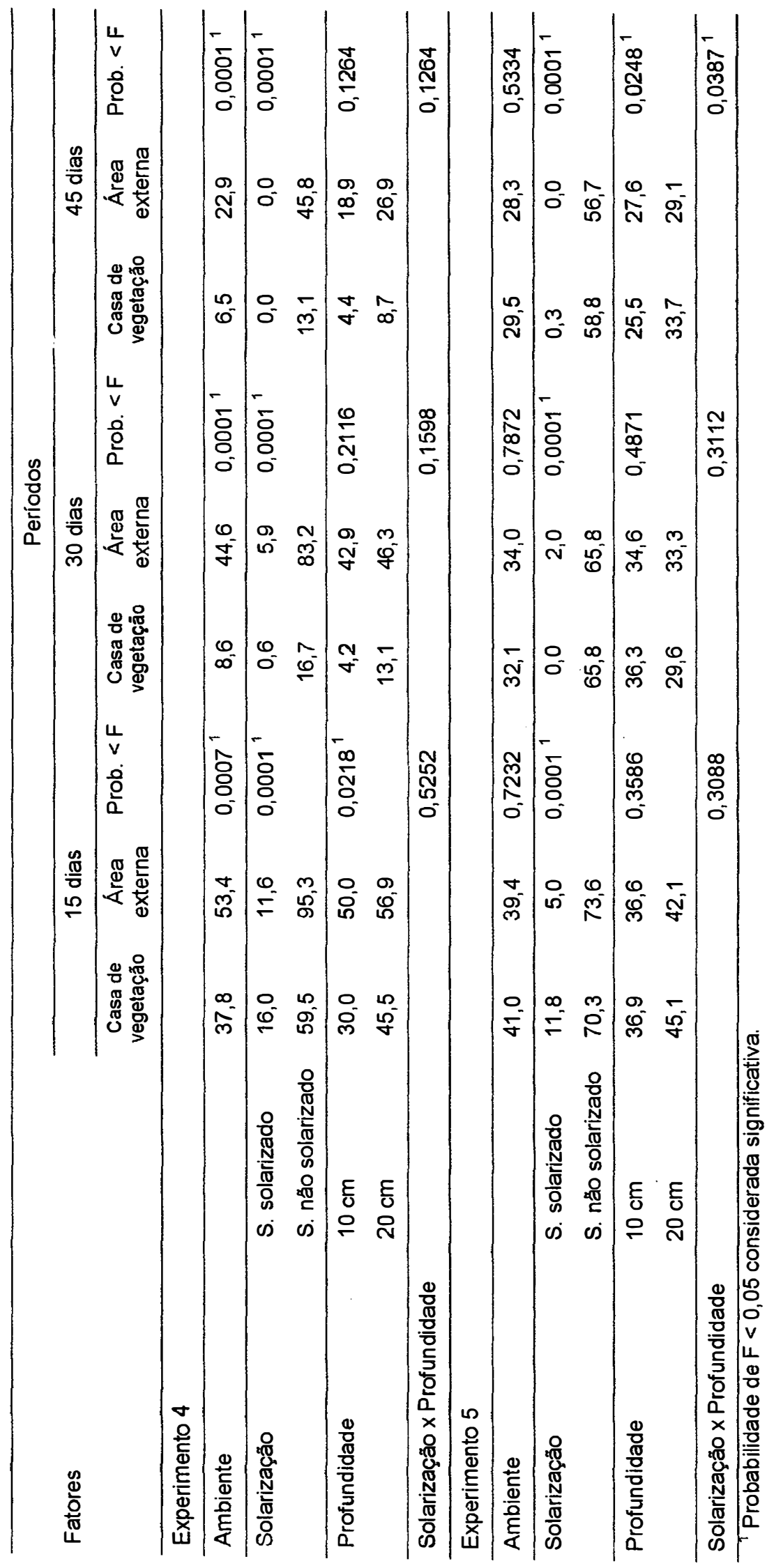

.

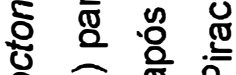

는 음

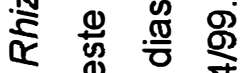

\% $\stackrel{0}{=}$ 守

\%

음

직 는

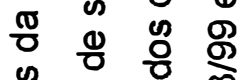

步

ำ

它 
Experimento 4

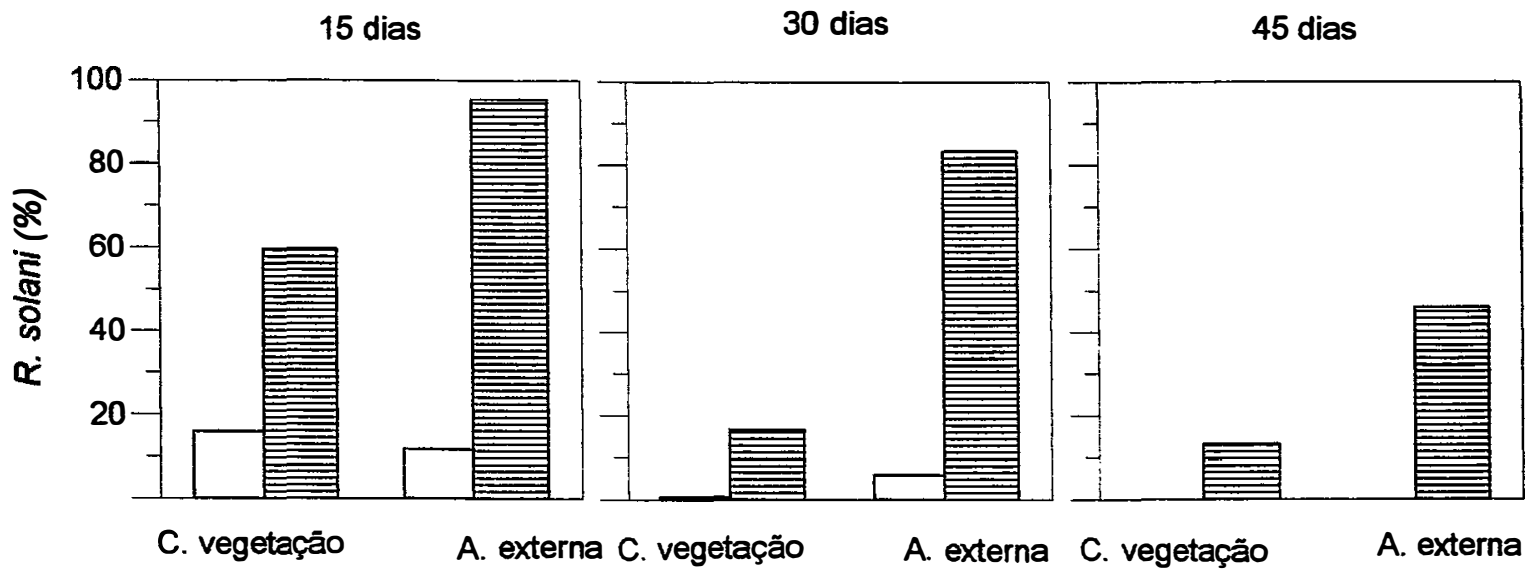

Experimento 5

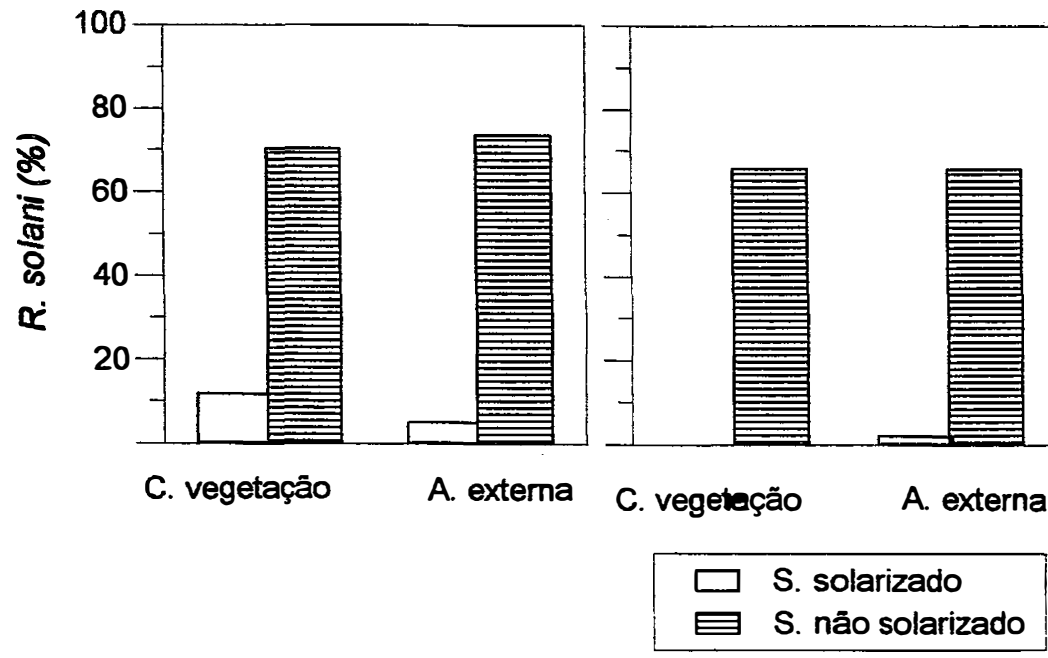

Figura 11. Médias da viabilidade de Rhizoctonia solani, avaliada pela porcentagem de sementes com micélio viável do patógeno, dos tratamentos solarizados e não solarizados, dentro da casa de vegetação e na área extema, em avaliações aos 15, 30 e 45 dias após o início dos experimentos 4 e 5 realizados, respectivamente, nos periodos de 29/01 a 11/03/99 e 28/02 a 16/04/99. Piracicaba, SP. 

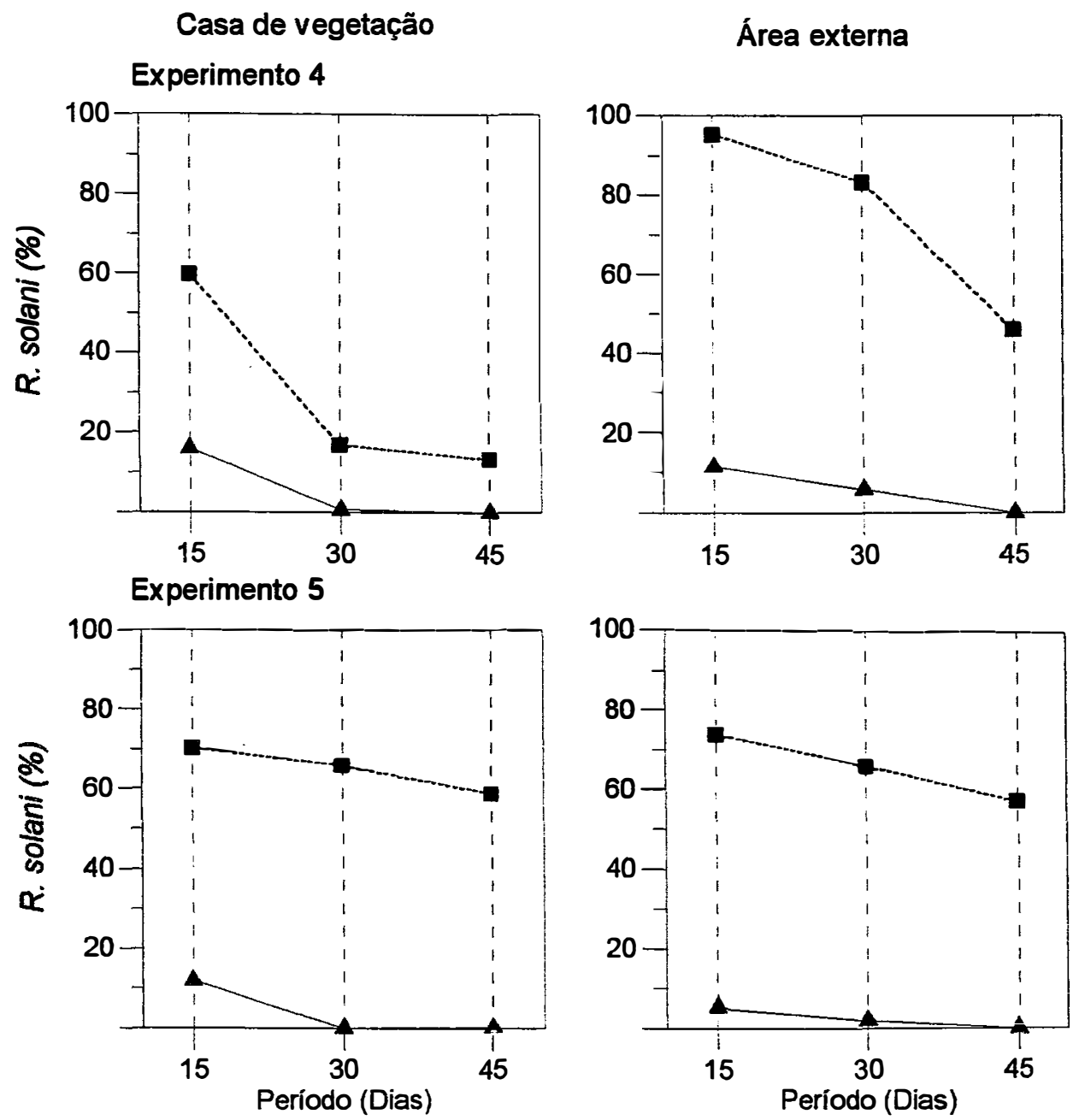

$$
\begin{aligned}
& \text { — S. solarizado } \\
& \text { - S. não solarizado }
\end{aligned}
$$

Figura 12. Médias da viabilidade de Rhizoctonia solani, avaliada pela porcentagem de sementes com micélio viável do patógeno, dos tratamentos solarizados e não solarizados, aos 15, 30 e 45 dias após o início dos experimentos 4 e 5, realizados, respectivamente nos períodos de 29/01 a 11/03/99 e 28/02 a 16/04/99, dentro da casa de vegetação na área externa. Piracicaba, SP. 


\subsubsection{Discussão dos experimentos de solarização}

\subsubsection{Temperaturas}

Nos primeiros experimentos, de números 1 e 2 , as temperaturas médias às 15:00 horas das parcelas solarizadas foram semelhantes entre os ambientes, e nos experimentos de 3 a 5 foram um pouco menores na casa de vegetação, variáveis entre 0,5 e $3,8^{\circ} \mathrm{C}$. Como a solarização ocorre em ciclos, com aquecimento durante o dia que culmina com temperaturas mais elevadas em tomo das 15:00 ou 16:00 horas e esfriamento durante a noite, as temperaturas atingidas na casa de vegetação são conseqüência do balanço de dois aspectos contraditórios. Segundo Mahrer (1991) a cobertura das casas de vegetação reduz a radiação total que incide sobre o solo; entretanto as temperaturas mais altas, que prevalecem no seu interior, tendem a reduzir as perdas de calor. Nos primeiros experimentos a área vedada era menor estimando-se que isso possibilitou a manutenção de um ambiente mais quente, com menor perda de calor, resultando em temperaturas médias e máximas mais elevadas dentro deste ambiente - média de 45,6 e máxima de $55,4^{\circ} \mathrm{C}$. Este periodo de verão em que foram realizados os experimentos foi muito quente e favorável à solarização. Para os experimentos seguintes, de números 3 a 5 , a área vedada foi bem maior, tomandose mais difícil a manutenção de temperaturas elevadas na casa de vegetação. Com as chuvas constantes deste ano-agricola, inclusive com chuva de granizo, nos experimentos 4 e 5 , foram notadas pequenas rachaduras nos plásticos da cobertura da casa de vegetação. No experimento 5 estas rachaduras se tomaram mais intensas tendo também ocorrido ruptura nos plásticos utilizados para vedação das laterais, que resultou em menor eficiência do processo nas parcelas solarizadas e não solarizadas da casa de vegetação.

Não foram detectadas diferenças marcantes entre as temperaturas obtidas nos tratamentos solarizados dentro e fora da casa de vegetação. Mahrer (1991), em um estudo em Israel, com base em temperaturas avaliadas externamente, entre o solo e a cobertura plástica, e no solo sob o plástico, desenvolveu um modelo para prever a temperatura obtida nos tratamentos solarizados. Ao testar o modelo, o autor comparou 
a solarização no interior de casas de vegetação à efetuada em áreas descobertas, verificando maiores temperaturas nas primeiras $\left(3\right.$ a $5^{\circ} \mathrm{C}$ ), que dependiam da cobertura da casa de vegetação. O trabalho mostrou que a solarização em casas de vegetação de vidro foi mais eficiente que a solarização dentro de casas de vegetação com polietileno, pouco mais eficiente que em área extema. Garibaldi \& Gullino (1991) encontraram diferenças marcantes entre os tratamentos no interior de casas de vegetação de vidro comparadas com áreas descobertas na Itália. As temperaturas máximas obtidas em casas de vegetação solarizadas, a 12 e a $25 \mathrm{~cm}$ de profundidade foram, respectivamente, 9 e $4^{\circ} \mathrm{C}$ mais elevadas que em áreas solarizadas extemamente. Nestas condições os tratamentos solarizados mantiveram temperaturas acima de $40^{\circ} \mathrm{C}$ por maior tempo - 48,5 horas na casa de vegetação e 7 horas na área extema (Garibaldi \& Gullino, 1991). A solarização dentro de casas de vegetação pode ser comparada à dupla solarização e, com esta técnica Raymundo \& Alcazar (1986) obtiveram uma temperatura $12,5^{\circ} \mathrm{C}$, e Duff \& Connely (1993) na Austrália, $6,4^{\circ} \mathrm{C}$ mais elevada que na solarização simples a $25 \mathrm{~cm}$ de profundidade. $O$ efeito da dupla solarização pode ser mais significativo pois o tratamento é efetuado com plástico transparente, em ambientes pequenos, com grande penetração de luz e pequena perda de calor. O mesmo não ocorreu na casa de vegetação utilizada nos presentes experimentos, coberta com plástico de polietileno e com telas nas laterais que reduziam a penetração de luz. A área utilizada foi relativamente grande, dificultando a adequada vedação, facilmente obtida em experimentos de dupla solarização.

As temperaturas médias do solo, entre 40,0 e $45,6^{\circ} \mathrm{C}$, e máximas, entre 49,3 a $55,6^{\circ} \mathrm{C}$, obtidas a $10 \mathrm{~cm}$ dentro da casa de vegetação, nos experimentos conduzidos no verão foram comparáveis às temperaturas obtidas em outros locais e países. Na Grécia, Tjamos et al. (1989) registraram temperaturas de $50^{\circ} \mathrm{C}$ a $10 \mathrm{~cm}$ de profundidade dentro de casas de vegetação e Bourbos \& Skoudridakis (1996) verificaram temperaturas médias máximas de 58,3 e $57,5^{\circ} \mathrm{C}$ nos anos de 1993 e 1994 , a $10 \mathrm{~cm}$ de profundidade, superiores às do solo não solarizado, que foram de 49,1 e $48^{\circ} \mathrm{C}$, para os anos de 1993 e 1994, respectivamente. Temperaturas máximas de $51^{\circ} \mathrm{C}$ para solo solarizado a $15 \mathrm{~cm}$ de profundidade foram obtidas em casas de vegetação no sul da Itália (Cartia \& Cipriano, 1989) e no norte deste pais, foram registradas temperaturas máximas de $48^{\circ} \mathrm{C}$, nestas mesmas condições (Garibaldi \& Tamieti, 1989). A solarização de canteiros elevados dentro de casas de vegetação resultou em 
temperaturas máximas de $45^{\circ} \mathrm{C}$ a $15 \mathrm{~cm}$ de profundidade (Gulino et al., 1998). A dupla solarização pode apresentar temperaturas mais elevadas, pois nesta condição Raymundo \& Alcazar (1986) obtiveram a temperatura de $60^{\circ} \mathrm{C}$ e Duff \& Connelly (1993) de $51^{\circ} \mathrm{C}$ a $25 \mathrm{~cm}$ de profundidade. Em locais menos favoráveis, o processo não é tão eficiente, pois Le Bihan et al. (1997) obtiveram temperaturas máximas de $49,9^{\circ} \mathrm{C}$ a 5 $\mathrm{cm}$ e de $44^{\circ} \mathrm{C}$ a $15 \mathrm{~cm}$ de profundidade, com a dupla solarização de sementeiras de espécies florestais, na França.

Mahrer (1991) estimou, em Israel, que existe um período bem maior, em meses, favorável à solarização dentro de casas de vegetação que em áreas externas, principalmente nas estufas cobertas com vidro. Nos experimentos efetuados nesta tese, não foram detectadas grandes diferenças nas temperaturas obtidas nos tratamentos solarizados dentro e fora da casa de vegetação. Também no presente trabalho, em avaliação de temperatura dentro e fora da casa de vegetação, efetuada em setembro-outubro, a $10 \mathrm{~cm}$ de profundidade nas parcelas solarizadas, as temperaturas foram semelhantes em ambos os ambientes e pouco favoráveis ao controle de fitopatógenos, com média de $35,6^{\circ} \mathrm{C}$ dentro da casa de vegetação e de $35,5^{\circ} \mathrm{C}$ na área externa. Como as temperaturas encontradas neste experimento foram semelhantes dentro e fora da casa de vegetação, estima-se que os períodos considerados satisfatórios para a solarização em ambiente externo, que se concentram nos meses de novembro, dezembro e janeiro, que podem ser estendidos até fevereiro na região de Campinas (Ghini et al., 1994) também são os mais favoráveis à solarização em casas de vegetação na região de Piracicaba. No último ano-agrícola os meses de novembro e dezembro foram extremamente chuvosos, e foram registradas temperaturas elevadas até o mês de março, podendo-se inferir, portanto, que o tratamento possa ser estendido até este mês.

\subsubsection{Viabilidade de Pythium aphanidermatum}

O método utilizado para determinar a viabilidade, pela avaliação da porcentagem de tombamento de pós-emergência, mostrou-se prático e de baixo custo. Neste método avalia-se o potencial infeccioso do solo (Lourd, 1986, 1987), que é definido por Bouthot (1980, citado por Lourd, 1986) como sendo a quantidade de energia patogênica disponivel dentro de um solo infestado. $O$ teste procura confrontar 
uma população de plantas hospedeiras suscetiveis, como pepino, com solo misturado a farinha de aveia, favorecendo a expressão da patogenicidade de Pythium spp. 0 teste é considerado qualitativo, mas a intensidade do tombamento foi utilizada por Lourd et al. $(1986,1987)$ como uma medida da infestação dos solos da Amazônia. Como a avaliação quantitativa precisa do potencial infeccioso seria muito trabalhosa, considerou-se neste trabalho a intensidade de tombamento como uma medida da viabilidade de Pythium aphanidermatum, a única espécie identificada em vários isolamentos do patógeno. Ao avaliar os resultados, porém, é preciso considerar que o patógeno está sendo favorecido por este teste, podendo, em condições normais, não estar causando danos tão intensos às culturas.

Considerando todos os experimentos realizados, observa-se que Pythium aphanidermatum só foi controlado pela solarização nos experimentos 1 - dentro e fora da casa de vegetação, foi parcialmente controlado no experimento 2 - dentro da casa de vegetação, e nos experimentos 3 e 5 apenas nas camadas superficiais do solo.

Stapleton \& DeVay (1995) incluem Pythium aphanidermatum entre os patógenos parcialmente ou não controlados pela solarização, embora Pythium ultimum e espécies de Pythium (Katan, 1991; Stapleton \& DeVay, 1995) estejam listadas entre os patógenos controlados pela solarização. Um importante aspecto a ser considerado é que espécies de Pythium mostram diferentes adaptações ao ambiente. $P$. aphanidermatum apresenta crescimento em ágar em grande amplitude térmica, até a $46{ }^{\circ} \mathrm{C}$ (Waterhouse \& Watson, 1964). Temperaturas elevadas e solos encharcados predispõem o hospedeiro ao ataque por este patógeno (Waterhouse \& Watson, 1964). Este patógeno parece ser bem adaptado a condições climáticas tropicais tendo sido encontrado com grande freqüência em solos da região amazônica, cultivados ou com mata (Lourd et al., 1986, 1987). P. aphanidermatum apresentou patogenicidade a plântulas de soja em um grande intervalo de temperatura, 15 a $36{ }^{\circ} \mathrm{C}$, enquanto outras espécies como $P$. debarianum e $P$ ultimum foram patogênicas apenas em temperaturas entre 15 e $22,5^{\circ} \mathrm{C}$ (Tomson et al., 1971). Outro aspecto a ser considerado é que a temperatura letal a espécies de Pythium é variável de acordo com a espécie envolvida e a formação de oósporos (Bollen, 1985). A temperatura letal a $P$. aphanidermatum, após 30 minutos de exposição em cultura em solo, foi maior que $52,5^{\circ} \mathrm{C}$ (Bollen, 1985 ), enquanto para $P$. ultimum a inativação térmica ocorreu a 34 minutos a $50^{\circ} \mathrm{C}, 180$ minutos a $47^{\circ} \mathrm{C}, 9$ horas a $45^{\circ} \mathrm{C}, 45$ horas a $42^{\circ} \mathrm{C}$, e 20 dias a 
$37^{\circ} \mathrm{C}$ (Pullman et al., 1981). P. aphanidermatum forma grande quantidade de oósporos em solo, condição que aumenta sua resistência ao calor (Bollen, 1985).

No experimento 1 , em um verão favorável à solarização, foi obtido o controle do patógeno após 40 dias de tratamento dentro da casa de vegetação, provavelmente porque a temperatura máxima alcançada nesta condição $-54{ }^{\circ} \mathrm{C}$ a $10 \mathrm{~cm}$ de profundidade - foi suficiente para inativar o patógeno. Nos experimentos seguintes as temperaturas alcançadas foram menores, resultantes de condições climáticas menos favoráveis, não sendo obtido controle consistente do patógeno. Nos experimentos 2 e 3 , quando houve interação entre solarização e profundidade, observa-se que nas camadas superficiais dos tratamentos solarizados houve redução na viabilidade do patógeno, o contrário ocorrendo a $20 \mathrm{~cm}$ de profundidade. Como este patógeno é resistente ao calor e forma oósporos, pode ter sido favorecido pelas temperaturas subletais alcançadas nesta profundidade. Embora temperaturas subletais possam enfraquecer propágulos de muitos patógenos, podem ter pouco efeito sobre oósporos. Em geral sobrevive à solarização, uma população residual que inclui "agentes de biocontrole", como Pseudomonas fluorescentes e diversos fungos (Griffin \& Baker, 1991). Entretanto, caso ocorra sobrevivência de patógenos, estes poderão se multiplicar, e, favorecidos pela ruptura no equilibrio biológico e na capacidade tampão do solo, as doenças provocadas pelos mesmos poderão se acentuar (Griffin \& Baker, 1991). Koch (1999), ao detectar maior pressão de infeção provocada por $P$. ultimum adicionado a substrato tratado com calor $\left(60^{\circ} \mathrm{C}\right.$ por 24 horas), observa que Pythium rapidamente recoloniza substratos e solos após tratamentos térmicos em casas de vegetação. Nestes experimentos podem ter sobrevivido ao tratamento, principalmente nas camadas mais profundas do solo, propágulos que podem ter sido favorecidos pela redução na população microbiana do solo e pela sua capacidade de rápida recolonização. A complexidade das interações entre microrganismos presentes no solo pode explicar a variabilidade dos resultados.

As diferentes sensibilidades térmicas das espécies de Pythium e as diversas temperaturas alcançadas durante os experimentos de solarização podem explicar os resultados diversos dos experimentos. Espécies de Pythium foram controladas com solarização em raizes de Gypsophila (Gamliel et al., 1989) e em crisântemo (Bettiol et al.,1994). Propágulos de Pythium myriotilum perderam a viabilidade a $25 \mathrm{~cm}$ de profundidade sob solarização simples e dupla na Austrália (Duff \& Connelly, 1993). 
Pythium spp. foi controlado apenas com solarização dupla em túneis plásticos, não sendo controlado pela solarização simples, em Valência, na Espanha (Cebolla et al., 1995), e apenas nas camadas superficiais de sementeiras de espécies florestais na França (Le Bihan et al., 1997).

Embora não tenha sido consistentemente controlado pela solarização neste trabalho, $P$. aphanidermatum foi erradicado em coletor solar, que alcançou temperatura máxima de $80^{\circ} \mathrm{C}$ (Ghini, 1993) e em plântulas de melancia após 30 dias de exposição à solarização no Irã (Mansoori \& Jaliani, 1996), com temperaturas máximas de $49^{\circ} \mathrm{C}$ a $25 \mathrm{~cm}$ de profundidade. A temperatura alcançada pelo coletor solar pode explicar o controle. Outros fatores podem ter determinado a maior eficiência do processo no Irã.

\subsubsection{Viabilidade de Rhizoctonia solani}

Como o isolado de $R$. solani utilizado apresentou formação de escleródios rapidamente em laboratório, muitas das sementes colocadas no solo apresentaram escleródios ao seu redor. Considerando que o número de amostras processado foi elevado e a sensibilidade térmica de micélio e escleródios de $R$. solani é semelhante (Silva et al., 1996) não foi avaliada a presença e a viabilidade de escleródios nas sementes e no solo.

A viabilidade de Rhizoctonia solani decresceu nos tratamentos solarizados, em ambos os ambientes, em todos os experimentos efetuados. A redução na viabilidade ocorreu também nas parcelas não solarizadas dentro da casa de vegetação. $\mathrm{Na}$ área externa, não solarizada, verificou-se redução parcial da viabilidade devida, provavelmente à exposição do patógeno à população microbiana do solo, já que as sementes ao serem retiradas e incubadas apresentaram, além de $R$. solani, outros fungos como Fusarium, Penicillium, Trichoderma e outros não identificados. Também as condições climáticas foram adversas durante os experimentos 1,4 e 5 , apresentando temperaturas elevadas no solo não solarizado em janeiro de $1998 \mathrm{e}$ chuvas excessivas em janeiro - fevereiro de 1999.

Como nestes experimentos, outros autores obtiveram controle de $R$. solani empregando a solarização em campo aberto (Pullman et al., 1981; Kaewruang et al., 1989), em casas de vegetação (Garibaldi \& Tamietti, 1989; Gulino et al., 1998) e em coletor solar (Ghini et al., 1992). O controle foi menos efetivo em locais menos 
favoráveis, como no sul da França, em que o patógeno só foi controlado em sementeiras de espécies florestais com dupla solarização e nas camadas mais superficiais do solo (Le Bihan, 1997) e na Espanha, com controle obtido apenas com solarização dupla em túneis plásticos (Cebolla et al., 1995).

Nos experimentos 1 e 2 a erradicação do patógeno em ambas as profundidades foi obtida após 20 dias de exposição à solarização na casa de vegetação, ao passo que na área extema esta ocorreu após 40 dias de tratamento. Embora as temperaturas médias dos solos solarizados tenham sido semelhantes para ambos os ambientes, as maiores temperaturas obtidas às 8:00 horas na casa de vegetação, indicam que a redução nas perdas de calor durante a noite pode estar associada à redução no período de tratamento. Nos experimentos 4 e 5 a erradicação do patógeno foi obtida apenas após 30 dias de tratamento, possivelmente porque nestes a área tratada foi maior, houve problemas na vedação da casa de vegetação e as condições climáticas foram menos favoráveis. Em todos os experimentos em campo aberto a erradicação do patógeno ocorreu após 40 dias de tratamento, indicando que, nesta época do ano, este é o período considerado necessário ao tratamento. Estima-se que os períodos de tratamento de 30 dias para a casa de vegetação avaliada e de 40 dias para a área externa, no verão, são suficientes para promover o controle do patógeno. Pullman et al., (1981) relatou que um período de 14 dias de solarização, na época mais quente do ano, foi suficiente para promover o controle de $R$. solani em solo cultivado com algodão. Um período de 3 semanas, nos meses de janeiro e fevereiro, foi necessário para desinfestar substrato utilizado para o plantio de gerbera na Austrália (Kaewruang et al., 1989). Foi necessário um período de 40 dias de tratamento para o controle deste patógeno em canteiros elevados no interior de casas de vegetação na Itália (Gulino et al., 1998). Em regiões menos favoráveis foram necessários 30 dias e 4 a 7 semanas, além de dupla solarização para o controle deste patógeno na Espanha e França, respectivamente (Cebolla et al., 1995, Le Bihan et al., 1997).

Comparando-se os experimentos, observa-se que o periodo necessário para a erradicação do patógeno foi função das temperaturas médias e máximas alcançadas nos tratamentos solarizados, e no tratamento sem cobertura plástica dentro da casa de vegetação. Embora o controle proporcionado pela solarização seja uma combinação de diversos fatores, a temperatura do solo é a variável que mais influi no processo de 
desinfestação (Souza, 1994). Pullman et al. (1981), ao observarem uma relação logaritmica entre a temperatura letal e o tempo de exposição ao calor constante, verificaram que $R$.solani, não apresentava viabilidade após 12 minutos a $50^{\circ} \mathrm{C}$. Este patógeno perdeu a viabilidade após a exposição do micélio à temperatura de $50^{\circ} \mathrm{C}$ por 30 minutos (Lefèvre \& Souza, 1993). As temperaturas ocorrentes às 15:00, com médias variáveis entre 45,3 e 40,0 e máximas entre 54,5 a 48,5 às 15:00 horas a 10 $\mathrm{cm}$ de profundidade dos tratamentos solarizados foram suficientes para erradicação do patógeno e indicam que a solarização no verão é uma altemativa ao controle deste patógeno dentro de casa de vegetação e em campo aberto.

No último experimento efetuado, número 5 , como a vedação da estufa foi prejudicada, as parcelas não solarizadas não apresentaram redução na viabilidade de $R$. solani, ao contrário do observado nos demais experimentos. Embora o patógeno tenha sido controlado nas parcelas solarizadas, a vedação da casa de vegetação poderá estar associada à maior eficiência do processo e à redução do período de tratamento nesta condição. 


\subsection{Avaliação da integração da solarização com controle biológico ou químico}

\subsubsection{Obtenção dos isolados de Trichoderma spp. antagônicos a Pythium aphanidermatum e Rhizoctonia solani}

Foram obtidos 31 isolados oriundos dos solos do Instituto Biológico em Campinas e da ESALQ - USP e 25 isolados das sementes enterradas nos experimentos de solarização. Quase todos os isolados foram coletados das iscas colonizadas com $R$. solani, com exceção do 29 , obtido de sementes colonizadas com $P$. aphanidermatum. Escolheram-se apenas os isolados com crescimento micelial e esporulação típicos de Trichoderma spp., abundantes sobre as iscas.

\subsubsection{Seleção in vitro}

4.2.2.1 Avaliação de antagonismo de isolados de Trichoderma spp. a Pythium aphanidermatum e Rhizoctonia solani

As notas segundo as classes de cada isolado pareado com $P$. aphanidermatum e $R$. solani encontram-se na Tabela 13, para os isolados retirados das iscas em solos de diversos locais, e na Tabela 14, para os isolados obtidos dos experimentos de solarização.

$\mathrm{O}$ isolado 1 (experimento 6) e os isolados 12, 15 e 17 (experimento 7) apresentaram notas baixas quando pareados com ambos os patógenos, e o isolado 20 (experimento 7) apresentou menor nota frente a $R$. solani. Os isolados $26,27,28$ e 29 (experimento 8) e 17, 33 e 34 (experimento 9) apresentaram notas baixas frente a ambos os patógenos. Nestes dois experimentos, todos os isolados apresentaram notas baixas quando confrontados com $P$. aphanidermatum. Dentre os isolados oriundos dos experimentos de solarização, destacaram-se os isolados $3 S, 4 S$ e $5 S$ (experimento 10) e os isolados 20S, $21 \mathrm{~S}$ e $28 \mathrm{~S}$ (experimentos 11 e 12). Os isolados $25 \mathrm{~S}$ e $26 \mathrm{~S}$ apresentaram notas baixas quando pareados $\operatorname{com} P$. aphanidermatum. 
Tabela 13. Notas (classe 1 a 5) de isolados de Trichoderma spp. obtidos de solos de Campinas e Piracicaba, pareados com Pythium aphanidematum e Rhizoctonia solani, avaliados 120 horas após o plaqueamento.

\begin{tabular}{|c|c|c|c|}
\hline \multirow[t]{2}{*}{ Experimentos } & \multirow{2}{*}{$\begin{array}{c}\begin{array}{c}\text { Isolados de } \\
\text { Trichoderma } \\
\text { spp. }\end{array} \\
\end{array}$} & $\begin{array}{c}\text { Pythium } \\
\text { aphanidermatum }\end{array}$ & $\begin{array}{c}\text { Rhizoctonia } \\
\text { solani }\end{array}$ \\
\hline & & \multicolumn{2}{|c|}{ Classe (1-5) } \\
\hline Experimento 6 & $\begin{array}{c}1 \\
2 \\
3 \\
4 \\
5 \\
6 \\
7 \\
8 \\
9 \\
10 \\
11 \\
\end{array}$ & $\begin{array}{c}2,0^{1} \\
4,0 \\
4,0 \\
4,0 \\
4,0 \\
4,0 \\
4,0 \\
4,0 \\
4,0 \\
4,0 \\
4,0 \\
\end{array}$ & $\begin{array}{l}2,0 \mathrm{a}^{2} \\
2,7 \mathrm{ab} \\
3,0 \mathrm{~b} \\
2,0 \mathrm{a} \\
3,0 \mathrm{~b} \\
3,0 \mathrm{~b} \\
3,3 \mathrm{bc} \\
2,0 \mathrm{a} \\
2,7 \mathrm{ab} \\
4,0 \mathrm{c} \\
4,0 \mathrm{c} \\
\end{array}$ \\
\hline & CV (\%) & S/variância & 10,7 \\
\hline Experimento 7 & $\begin{array}{l}12 \\
13 \\
14 \\
15 \\
17 \\
18 \\
19 \\
20 \\
22 \\
23 \\
\text { CV (\%) }\end{array}$ & $\begin{array}{l}2,0 \mathrm{ab} \\
4,0 \mathrm{~d} \\
3,7 \mathrm{~cd} \\
2,7 \mathrm{abc} \\
2,7 \mathrm{abc} \\
4,2 \mathrm{~d} \\
4,0 \mathrm{bcd} \\
4,0 \mathrm{abc} \\
4,0 \mathrm{~d} \\
4,0 \mathrm{a} \\
13,3\end{array}$ & $\begin{array}{l}2,0 \mathrm{a} \\
2,7 \mathrm{ab} \\
3,0 \mathrm{~b} \\
2,0 \mathrm{a} \\
3,0 \mathrm{~b} \\
3,0 \mathrm{~b} \\
3,3 \mathrm{bc} \\
2,0 \mathrm{a} \\
2,7 \mathrm{ab} \\
4,0 \mathrm{c} \\
17,5\end{array}$ \\
\hline Experimento 9 & $\begin{array}{l}17 \\
30 \\
33 \\
34 \\
\end{array}$ & $\begin{array}{l}1,7 \mathrm{a} \\
2,0 \mathrm{a} \\
2,0 \mathrm{a} \\
1,7 \mathrm{a}\end{array}$ & $\begin{array}{l}2,6 \mathrm{ab} \\
4,0 \mathrm{~b} \\
2,3 \mathrm{ab} \\
2,0 \mathrm{a}\end{array}$ \\
\hline & CV (\%) & 11,13 & 23,5 \\
\hline
\end{tabular}

Classe 1 = Trichoderma cresce sobre o patógeno e ocupa toda a superfície do meio;

Classe 2 = Trichoderma cresce sobre pelo menos $2 / 3$ da superficie do meio;

Classe 3 = Trichoderma e o patógeno ocupam aproximadamente metade da superfície do meio,

Classe $4=$ Trichodema cresce sobre $1 / 3$ da superficie do meio,

Classe 5 = Trichoderma não cresce e o patógeno ocupa toda a superficie da placa.

${ }^{2}$ Médias seguidas pela mesma letra não diferem entre si (Tukey $5 \%$ ) 
Tabela 14. Notas (classe 1 a 5) de isolados de Trichoderma spp., obtidos a partir dos experimentos de solarização, pareados com Pythium aphanidermatum e Rhizoctonia solani, avaliados 120 horas após o plaqueamento.

\begin{tabular}{|c|c|c|c|}
\hline \multirow[t]{2}{*}{ Experimentos } & \multirow{2}{*}{$\begin{array}{l}\text { Isolados de } \\
\text { Trichoderma } \\
\text { spp. }\end{array}$} & $\begin{array}{c}\text { Pythium } \\
\text { aphanidermatum }\end{array}$ & $\begin{array}{c}\text { Rhizoctonia } \\
\text { solani }\end{array}$ \\
\hline & & \multicolumn{2}{|c|}{ Classe (1-5) } \\
\hline Experimento 10 & $\begin{array}{l}1 S \\
2 S \\
3 S \\
4 S \\
5 S \\
6 S\end{array}$ & $\begin{array}{l}3,0{ }^{1} b^{2} \\
4,0 \mathrm{~d} \\
2,0 \mathrm{a} \\
1,7 \mathrm{a} \\
2,3 \mathrm{ab} \\
3,0 \mathrm{bc}\end{array}$ & $\begin{array}{l}2,3 \mathrm{a} \\
- \\
1,5 \mathrm{a} \\
1,8 \mathrm{a} \\
1,7 \mathrm{a} \\
2,0 \mathrm{a}\end{array}$ \\
\hline & CV (\%) & 11,4 & 20,8 \\
\hline Experimento 11 & $\begin{array}{l}10 \mathrm{~S} \\
11 \mathrm{~S} \\
12 \mathrm{~S} \\
14 \mathrm{~S} \\
15 \mathrm{~S} \\
16 \mathrm{~S} \\
17 \mathrm{~S} \\
18 \mathrm{~S} \\
19 \mathrm{~S} \\
20 \mathrm{~S} \\
21 \mathrm{~S}\end{array}$ & $\begin{array}{l}3,0 \mathrm{abc} \\
3,7 \mathrm{abc} \\
4,0 \mathrm{c} \\
2,7 \mathrm{abc} \\
3,3 \mathrm{abc} \\
3,7 \mathrm{bc} \\
3,0 \mathrm{abc} \\
2,3 \mathrm{abc} \\
3,0 \mathrm{abc} \\
2,2 \mathrm{ab} \\
1,7 \mathrm{a}\end{array}$ & $\begin{array}{l}3,0 \mathrm{~b} \\
3,0 \mathrm{~b} \\
2,0 \mathrm{a} \\
3,0 \mathrm{~b} \\
3,0 \mathrm{~b} \\
3,0 \mathrm{~b} \\
2,3 \mathrm{ab} \\
2,3 \mathrm{ab} \\
3,0 \mathrm{~b} \\
2,0 \mathrm{a} \\
2,3 \mathrm{ab}\end{array}$ \\
\hline & CV (\%) & 19,3 & 11,4 \\
\hline Experimento 12 & $\begin{array}{l}22 \mathrm{~S} \\
24 \mathrm{~S} \\
25 \mathrm{~S} \\
26 \mathrm{~S} \\
27 \mathrm{~S} \\
28 \mathrm{~S} \\
29 \mathrm{~S} \\
\end{array}$ & $\begin{array}{l}4,0 \mathrm{~d} \\
3,7 \mathrm{~cd} \\
1,8 \mathrm{ab} \\
1,8 \mathrm{ab} \\
2,3 \mathrm{ab} \\
1,5 \mathrm{a} \\
2,7 \mathrm{bc}\end{array}$ & $\begin{array}{l}3,7 \mathrm{c} \\
3,0 \mathrm{bc} \\
3,0 \mathrm{bc} \\
2,0 \mathrm{a} \\
3,0 \mathrm{bc} \\
3,0 \mathrm{bc} \\
2,7 \mathrm{ab}\end{array}$ \\
\hline & CV (\%) & 16,0 & 11,4 \\
\hline \multicolumn{4}{|c|}{$\begin{array}{l}\text { Classe } 1 \text { = Trichoderma cresce sobre o patógeno e ocupa toda a superfície do meio; } \\
\text { Classe } 2 \text { = Trichoderma cresce sobre pelo menos } 2 / 3 \text { da superfície do meio; } \\
\text { Classe } 3=\text { Trichoderma e o patógeno ocupam aproximadamente metade da superfície do meio, } \\
\text { Classe } 4=\text { Trichodema cresce sobre } 1 / 3 \text { da superfície do meio, } \\
\text { Classe } 5=\text { Trichoderma não cresce e o patógeno ocupa toda a superfície da placa. }\end{array}$} \\
\hline
\end{tabular}

Observou-se que Pythium aphanidermatum apresentou crescimento muito rápido abrangendo, em 24 horas, $2 / 3$ das placas. Os isolados de Trichoderma spp. com maior capacidade de parasitismo cresceram e esporularam sobre o micélio do mesmo. Lifshitz et al. (1986) também observaram, na interação entre Pythium e Trichoderma spp., que o micélio deste último cresceu abundantemente sobre o 
patógeno, havendo intensa esporulação nos locais de contato. Rhizoctonia solani desenvolveu-se mais lentamente, tendo seu crescimento limitado pelo antagonista.

\subsubsection{Produção de substâncias tóxicas difusíveis por isolados de Trichoderma spp.}

A Tabela 15 mostra o diâmetro das colônias e a porcentagem de inibição dos patógenos no teste de produção de substâncias tóxicas difusíveis. No experimento 13 os isolados 1, 17, 23 e 26 inibiram o crescimento de $P$. aphanidermatum e os isolados $26,17,1$ e 23 reduziram o diâmetro de $R$. solani. $O$ isolado 8 , entretanto, não afetou o crescimento de ambos os patógenos. Os isolados 34,33 e $28 \mathrm{~S}$ produziram substâncias que inibiram o crescimento de $P$. aphanidermatum nos experimentos 14 , 15,16 , respectivamente. Nestes experimentos os isolados 13, 17, 23, 26 e 28 inibiram o crescimento de $R$. solani, porém parcialmente. Diferentes espécies de Trichoderma podem liberar diferentes substâncias tóxicas em meio de cultura. Sivan et al. (1984) observaram maior redução no diâmetro de colônias de $P$. aphanidermatum pela difusão de substâncias tóxicas por $T$. hamatum que por $T$ harzianum. Wolfheckel \& Jensen (1992) verificaram redução no desenvolvimento de colônias de $P$. ultimum provocada por substâncias tóxicas liberadas por isolados de $T$. harzianum e $G$. virens. Lifshitz et al. (1986) associaram a produção de substâncias tóxicas pelos antagonistas, com a conseqüente degradação das hifas de Pythium spp., a um dos possiveis mecanismos de controle do patógeno no solo.

O diâmetro das colônias de $P$. aphanidermatum e $R$. solani, desenvolvidas após o crescimento destes patógenos sobre o papel celofane, não foi reduzido para 0 primeiro patógeno e foi pouco reduzido para o segundo (experimento 14). Estes dados indicam que a inibição do crescimento de ambos os patógenos foi devida, principalmente, à difusão de substâncias tóxicas liberadas pelos isolados de Trichoderma e não ao consumo de nutrientes do meio. Dois a três dias após as avaliações, para alguns isolados, ocorreu crescimento dos patógenos nas placas, indicando que eles deixaram de ser inibidos pelas substâncias tóxicas liberadas no meio, o que também foi observado por Dennis \& Webster (1971). Os isolados 8, 17, 23 e 26 que foram utilizados repetidamente em alguns experimentos, mantiveram 0 mesmo comportamento com relação à capacidade de inibição. 
Tabela 15. Crescimento de colônias (em $\mathrm{mm}$ ) com 72 horas e porcentagem de inibição de Pythium aphanidermatum e Rhizoctonia solani em placas de Petri sobre BDA, colocadas após o crescimento, por 48 horas, de isolados de Trichoderma spp.

\begin{tabular}{|c|c|c|c|c|c|}
\hline \multirow[b]{2}{*}{ Experimentos } & \multirow{2}{*}{$\begin{array}{l}\text { Isolados de } \\
\text { Trichoderma } \\
\text { spp. }\end{array}$} & \multicolumn{2}{|c|}{ Diâmetro colônia (mm) } & \multicolumn{2}{|c|}{ \% Inibição } \\
\hline & & $\begin{array}{c}\text { Pythium } \\
\text { aphanidermatum }\end{array}$ & $\begin{array}{l}\text { Rhizoctonia } \\
\text { solani }\end{array}$ & $\begin{array}{c}\text { Pythium } \\
\text { aphanidermatum }\end{array}$ & $\begin{array}{l}\text { Rhizoctonia } \\
\text { solani }\end{array}$ \\
\hline \multirow[t]{7}{*}{ Experimento 13} & 1 & 4,0 & $9,0 a b$ & 95,6 & $85,7 a b$ \\
\hline & 8 & 90,0 & $55,3 \mathrm{C}$ & 0,0 & $12,2 \mathrm{c}$ \\
\hline & 17 & 4,0 & $7,8 a b$ & 95,6 & $87,7 a b$ \\
\hline & 23 & 4,0 & $14,0 \mathrm{~b}$ & 95,6 & $77,8 \mathrm{c}$ \\
\hline & 26 & 4,0 & $4,0 \mathrm{a}$ & 95,6 & 93,7 a \\
\hline & Testemunha & 90,0 & $63,0 \mathrm{c}$ & - & \\
\hline & CV(\%) & S/ variância & 18,3 & S/ variância & 11,6 \\
\hline \multirow[t]{7}{*}{ Experimento 14} & 8 & $90,0 \mathrm{~b}$ & $75,8 d$ & $0,0 \mathrm{~b}$ & $0,0 \mathrm{~d}$ \\
\hline & 17 & 9,8 a & $12,0 \mathrm{a}$ & $89,2 a$ & $81,4 \mathrm{~b}$ \\
\hline & 23 & 7,0 a & $9,0 \mathrm{a}$ & $92,2 \mathrm{a}$ & 86,1 a \\
\hline & 34 & $4,0 a$ & $48,5 \mathrm{~b}$ & 95,6 a & $24,8 \mathrm{c}$ \\
\hline & Rhiz/Pyth & $90,0 \mathrm{~b}$ & $64,5 \mathrm{c}$ & 0,0 & $13,6 \mathrm{~d}$ \\
\hline & Testemunha & $90,0 \mathrm{~b}$ & $73,5 d$ & - & - \\
\hline & CV(\%) & 6,2 & 5,0 & 5,8 & 2,9 \\
\hline \multirow[t]{6}{*}{ Experimento 15} & 13 & $12,3 \mathrm{~b}$ & $13,2 \mathrm{a}$ & $86,3 \mathrm{~b}$ & 82,1 a \\
\hline & 26 & $12,6 \mathrm{~b}$ & 14,5 a & $85,9 \mathrm{~b}$ & $80,3 a$ \\
\hline & 28 & $20,0 \mathrm{c}$ & $14,2 \mathrm{a}$ & $78,3 \mathrm{c}$ & 80,6 a \\
\hline & 33 & $4,0 \mathrm{a}$ & $30,0 \mathrm{~b}$ & 95,6 a & $59,2 \mathrm{~b}$ \\
\hline & Testemunha & $90,0 \mathrm{~d}$ & $73,5 \mathrm{c}$ & - & - \\
\hline & CV\% & 11,3 & 18,7 & 3,9 & 10,2 \\
\hline \multirow[t]{7}{*}{ Experimento 16} & $3 S$ & $90,0 \mathrm{~b}$ & $57.5 \mathrm{~b}$ & $0,0 \mathrm{~b}$ & $15,1 \mathrm{~b}$ \\
\hline & $4 S$ & $90,0 \mathrm{~b}$ & $57.1 \mathrm{~b}$ & $0,0 \mathrm{~b}$ & $15,7 \mathrm{~b}$ \\
\hline & $5 S$ & $90,0 \mathrm{~b}$ & $59.6 \mathrm{~b}$ & $0,0 \mathrm{~b}$ & $12,0 \mathrm{~b}$ \\
\hline & $21 S$ & $90,0 \mathrm{~b}$ & $80.8 d$ & $0,0 \mathrm{~b}$ & $0,0 \mathrm{~b}$ \\
\hline & $28 S$ & $7,0 \mathrm{a}$ & $19,0 \mathrm{a}$ & 92,2 a & $72,0 \mathrm{a}$ \\
\hline & Testemunha & $90,0 \mathrm{~b}$ & $67,8 \mathrm{bc}$ & - & - \\
\hline & $\mathrm{CV}(\%)$ & 1,4 & 8,8 & 6,9 & 32,9 \\
\hline
\end{tabular}

* Médias seguidas pela mesma letra não diferem entre si (Tukey 5\%) 


\subsubsection{Seleção in vivo}

\subsubsection{Antagonismo de isolados de Trichoderma spp. a Pythium aphanidermatum}

Experimentos 17e 18 - No experimento 17 (Tabela 16) a adição ao solo do isolado 26, nas duas doses, 5 e $10 \mathrm{~g}$ de sementes colonizadas/L de solo, proporcionou aumento significativo na porcentagem de plântulas sobreviventes, obtendo-se o melhor resultado com a maior dose. O tratamento químico (metalaxyl + mancozeb) foi o mais eficiente, não tendo apresentado tombamento. No experimento 18 (Tabela 17) a adição dos isolados 26 e 33 reduziu significativamente a ocorrência de tombamento. Outros autores também verificaram efeito de Trichoderma sobre o tombamento de plântulas de diversas culturas. $P$. aphanidermatum foi parcialmente controlado por isolados de Trichoderma harzianum em plântulas de pepino (Sivan et al., 1984; Wolfheckel \& Jensen, 1992), ervilha e tomate (Sivan et al., 1984) e T. virens em fumo (JackishMatsuura \& Menezes, 1999). Vários isolados de $T$. harzianum apresentaram controle de $P$. ultimum para algumas culturas, inclusive pepino (Harman et al., 1989). Harman et al. (1980) reduziram a incidência de tombamento provocado por Pythium spp pela adição de $T$. hamatum a sementes de ervilha. Koch (1999), entretanto, não obteve controle de $P$. ultimum em pepino pelo tratamento de substrato padronizado com produtos comerciais formulados com $T$. harzianum e $T$ viride.

Nos experimentos 17 e 18 os tratamentos biológicos apresentaram controle parcial do patógeno (Tabela 17), fato que Harman et al. (1980) também observaram, quando detectaram tombamento de pós-emergência no tratamento com $T$. hamatum, que não ocorreu no químico. $O$ tratamento químico do experimento 19 , foi mais eficiente que os biológicos, possivelmente porque o produto empregado - metalaxyl + mancozeb, é sistêmico e altamente eficaz para Pythium spp. (Morton, 1994). Harman et al. (1980) obtiveram melhor controle de Pythium spp. com PCNB que com $T$. hamatum, e Harman et al. (1989) verificaram que metalaxyl foi mais eficiente que o tratamento com $T$. harzianum para o controle de $P$. ultimum. 
Os isolados testados apresentaram crescimento micelial e esporulação abundante sobre os grãos de trigo em laboratório e no solo. Optou-se pela colonização dos isolados sobre grãos de trigo porque, segundo Papavizas (1985), a adição de Trichoderma ou Gliocladium na forma de micélio/conídios associados a uma base alimentar tende a reduzir a fungistase, aumentando o efeito antagônico dos mesmos, consequentemente melhorando a colonização do solo. Lewis \& Papavizas (1984) mostraram que a adição de Trichoderma na forma de micélio foi bem mais eficiente que uma suspensão de conídios. A proporção de grãos de trigo colonizados empregada neste trabalho foi semelhante à utilizada por Wolfheckel \& Jensen (1992), que obtiveram controle de $P$. ultimum com a proporção de $1 \%$ do antagonista colonizado sobre uma mistura de turfa e farelo de trigo.

Tabela 16. Plântulas de pepino sobreviventes ao tombamento de pós-emergência provocado por Pythium aphanidermatum, após o tratamento do solo com isolados de Trichoderma spp., nas doses de 5 e $10 \mathrm{~g}$ de sementes colonizadas $/ L$ de solo e com metalaxyl + mancozeb, em experimento realizado em casa de vegetação. Campinas, SP - Setembro-Outubro, 1998.

\begin{tabular}{lcc}
\hline Isolado & Dose $(\mathrm{g} / \mathrm{L}$ de solo) & Plântulas sobreviventes (\%) \\
\hline 1 & 5 & $21,8 \mathrm{ab}$ \\
& 10 & $17,2 \mathrm{a}$ \\
8 & 5 & $23,2 \mathrm{ab}$ \\
& 10 & $34,0 \mathrm{abc}$ \\
17 & 5 & $27,5 \mathrm{ab}$ \\
& 10 & $31,8 \mathrm{abc}$ \\
23 & 5 & $37,8 \mathrm{abc}$ \\
& 10 & $45,0 \mathrm{abc}$ \\
26 & 5 & $48,0 \mathrm{bc}$ \\
& 10 & $60,8 \mathrm{~cd}$ \\
Metalaxyl + mancozeb & & $98,2 \mathrm{e}$ \\
Testemunha & - & $19,8 \mathrm{ab}$ \\
\hline CV (\%) & - & 26,7 \\
\hline
\end{tabular}

'Médias seguidas pela mesma letra não diferem entre si (Tukey 5\%) 
Tabela 17. Plântulas de pepino sobreviventes ao tombamento de pós-emergência provocado por Pythium aphanidermatum, após o tratamento do solo com isolados de Trichoderma spp. na dose de $10 \mathrm{~g}$ de sementes colonizadas/ $\mathrm{L}$ de solo em experimento realizado em casa de vegetação. Campinas, SP Abril, 1999.

\begin{tabular}{lc}
\hline Isolados & Plântulas de pepino sobreviventes (\%) \\
\hline 1 & $51,4 \mathrm{ab}^{1}$ \\
8 & $47,7 \mathrm{~b}$ \\
13 & $55,7 \mathrm{ab}$ \\
17 & $54,5 \mathrm{ab}$ \\
23 & $49,1 \mathrm{ab}$ \\
26 & $64,6 \mathrm{a}$ \\
33 & $63,3 \mathrm{a}$ \\
Testemunha & $48,9 \mathrm{~b}$ \\
\hline CV (\%) & 11,0 \\
\hline
\end{tabular}

${ }^{1}$ Médias seguidas pela mesma letra não diferem entre si (Tukey 5\%)

No solo, apenas os tratamentos com os isolados 26 e 33 diferiram da testemunha, embora tenham sido empregados nos experimentos isolados que se destacaram, com exceção do 8, nos testes efetuados em laboratório (Tabelas 13 e 15). A colonização do solo foi eficientemente promovida com a adição dos isolados ao solo 7 dias antes dos tratamentos, além do revolvimento das misturas de isolados e solo. Broadbent et al. (1971, citado por Fravel, 1988) verificaram que agentes de biocontrole que não produziram antibióticos em ágar in vitro, não foram efetivos no solo e dentre os que os produziram apenas uma pequena porcentagem (4\%) foi efetiva no solo. Jackicsh-Matsuura \& Menezes (1999) também não observaram comportamento semelhante quando compararam o desempenho de isolados de Trichoderma in vitro com controle de $P$. aphanidermatum in vivo. 


\subsubsection{Antagonismo de isolados de Trichoderma spp. a Rhizoctonia solani}

\section{Experimento 19 -}

Os resultados de emergência do rabanete do experimento para verificar a capacidade antagônica de isolados de Trichoderma spp. encontram-se na Tabela 18. Neste experimento destacou-se o isolado 17 como o que apresentou maior controle do patógeno, seguido pelos isolados 8,1 e 14, em avaliações 5 dias após o plantio. 0 comportamento dos isolados durante os 4 dias seguintes (Figura 13), mostra que ocorreu proteção inicial à emergência das plântulas, que foi sucedida por tombamento, resultando em menor número de plantas, em todos os tratamentos, com exceção do químico. $O$ isolado 17 manteve superioridade no controle do patógeno, em relação aos demais isolados, durante todo o experimento.

Tabela 18. Plântulas de rabanete sobreviventes ao tombamento de pré e pósemergência provocado por Rhizoctonia solani, após o tratamento do solo com isolados de Trichoderma spp. na dose de $10 \mathrm{~g}$ de sementes colonizadas $/$ de solo e com pencycuron em experimento realizado em casa de vegetação . Campinas, SP - Abril - Maio, 1999.

\begin{tabular}{cc}
\hline Isolados & Plântulas sobreviventes (\%) \\
\hline 1 & $35,6 \mathrm{~cd}^{1}$ \\
8 & $44,0 \mathrm{~cd}$ \\
13 & $26,0 \mathrm{bcd}$ \\
23 & $2,6 \mathrm{a}$ \\
26 & $4,6 \mathrm{a}$ \\
33 & $18,6 \mathrm{ab}$ \\
17 & $59,6 \mathrm{ef}$ \\
28 S & $19,0 \mathrm{abc}$ \\
Pencycuron & $68,5 \mathrm{f}$ \\
Testemunha & $9,0 \mathrm{ab}$ \\
Solo s/ R. solani & $84,0 \mathrm{~g}$ \\
\hline CV (\%) & 30,7 \\
\hline
\end{tabular}

'Médias seguidas pela mesma letra não diferem entre si (Tukey $5 \%$ ) 
Como neste experimento, o controle de $R$. solani por isolados de Trichoderma também foi obtido por outros autores, em plântulas de diversas culturas, como rabanete (Harman et al. ,1980, Chet \& Baker, 1981), berinjela, tomate e feijão (Hadar et al., 1979), fumo (Cole \& Zvenyika, 1988) e alface (Coley-Smith et al., 1991. Trabalhos recentes têm empregado produtos comerciais cuja formulação é baseada, principalmente, em G. virens e espécies de Trichoderma. BINAB-T, um produto comercial formulado com $T$. viride, reduziu significativamente a incidência de podridão do pé provocada por $R$. solani em crisântemo (Orlikowski \& Wojdyla, 1996). Produtos biológicos formulados com $T$. harzianum, $G$. virens e uma mistura de $T$. hamatum e Flavobacterium balustinum controlaram o patógeno em bico-de-papagaio (Elmer \& Elliott, 1998). Walter \& Bruette (1996) verificaram o controle de $R$. solani com os produtos comerciais Soilgard (G. virens) e Bio-Trek ( $T$. harzianum). Ao testar quatro produtos biológicos comerciais, Koch (1999) obteve controle de $R$. solani com dois produtos comerciais: Supressivit ( $T$. harzianum) em um experimento e Soilgard ( $G$. virens) nos seis experimentos realizados.

Como nos experimentos anteriores, procurou-se favorecer a colonização do solo, optando-se por adicionar os isolados colonizados em sementes de trigo, também utilizadas por Hadar et al.(1979) e Noronha et al. (1996). Substratos baseados em outros grãos ou em farelo de trigo misturados a turfa foram empregados por outros autores (Chet \& Baker, 1981; Elad et al., 1981; Cole \& Svenika, 1988; Lewis et al., 1990; Coley-Smith et al., 1991). Utilizou-se a dose de $10 \mathrm{~g} / \mathrm{L}$ de solo de sementes de trigo colonizadas, pois foi a melhor no experimento 17 , realizado anteriormente com $P$. aphanidermatum em pepino. Outros autores como Henis et al. (1978) obtiveram controle de $R$. solani em rabanete com concentraçōes de $T$. harzianum variáveis de 0,1 a 4,0 g/kg de solo, e Hadar et al. (1979) obtiveram controle de tombamento provocado por $R$. solani em berinjela, tomate e feijão proporcional à dose de $T$. harzianum aplicada.

Alguns tratamentos apresentaram emergência inferior à das testemunhas, provavelmente porque a introdução do antagonista colonizado sobre grãos de trigo aumentou o potencial de inóculo do solo. Hadar et al. (1979) detectaram o dobro de tombamento causado por $R$. solani após a adição de farelo de trigo sem antagonistas ao solo. A quantidade de inóculo utilizada nos presentes experimentos foi elevada, 0 
que pode ter interferido nos resultados, pois, em geral, o controle biológico raramente é efetivo com elevada pressão do patógeno (Deacon \& Berry, 1993). Elmer \& Elliott (1998) mostraram que o controle de $R$. solani em bico-de-papagaio com produtos biológicos formulados com Trichoderma e $G$. virens foi menos efetivo com maior quantidade de inóculo ( $2 \mathrm{~g}$ inóculo de $R$. solanill de solo).

Os tratamentos biológicos, assim como a testemunha, embora tenham promovido a emergência, sofreram tombamento de pós-emergência, o que também foi observado por Harman et al. (1980) após o tratamento de sementes de rabanete e, por Elmer \& Elliott, (1998) em poinsetia (bico-de-papagaio).

Optou-se por adicionar os antagonistas aos solos 8 dias antes da aplicação dessas misturas nas plantas, para favorecer a colonização do solo pelos antagonistas. Orlikowski \& Wojdyla (1996) ao aplicarem BINAB-T (T. viride), também obtiveram melhor controle com a colonização prévia do solo por 3 dias em relação à adição simultânea ao plantio de crisântemo.

Neste experimento, o controle químico destacou-se possivelmente porque o produto empregado - pencycuron - é reconhecidamente eficiente para o controle de $R$. solani (Morton, 1994). Outros autores, como Coley-Smith et al. (1991), ao testarem tolclofos-methyl (Basilex) e isolados de $T$ viride e de $T$. harzianum em alface, e Elmer \& Elliott (1998) comparando o mesmo fungicida com produtos biológicos formulados com Trichoderma e G. virens em bico-de-papagaio, também observaram maior eficiência do controle químico. Por outro lado a adição de Trichoderma promoveu maior controle deste patógeno que os tratamentos com PCNB e captan em sementes (Harman et al., 1980) e PCNB no solo (Mihuta-Grimm \& Rowe, 1986). 


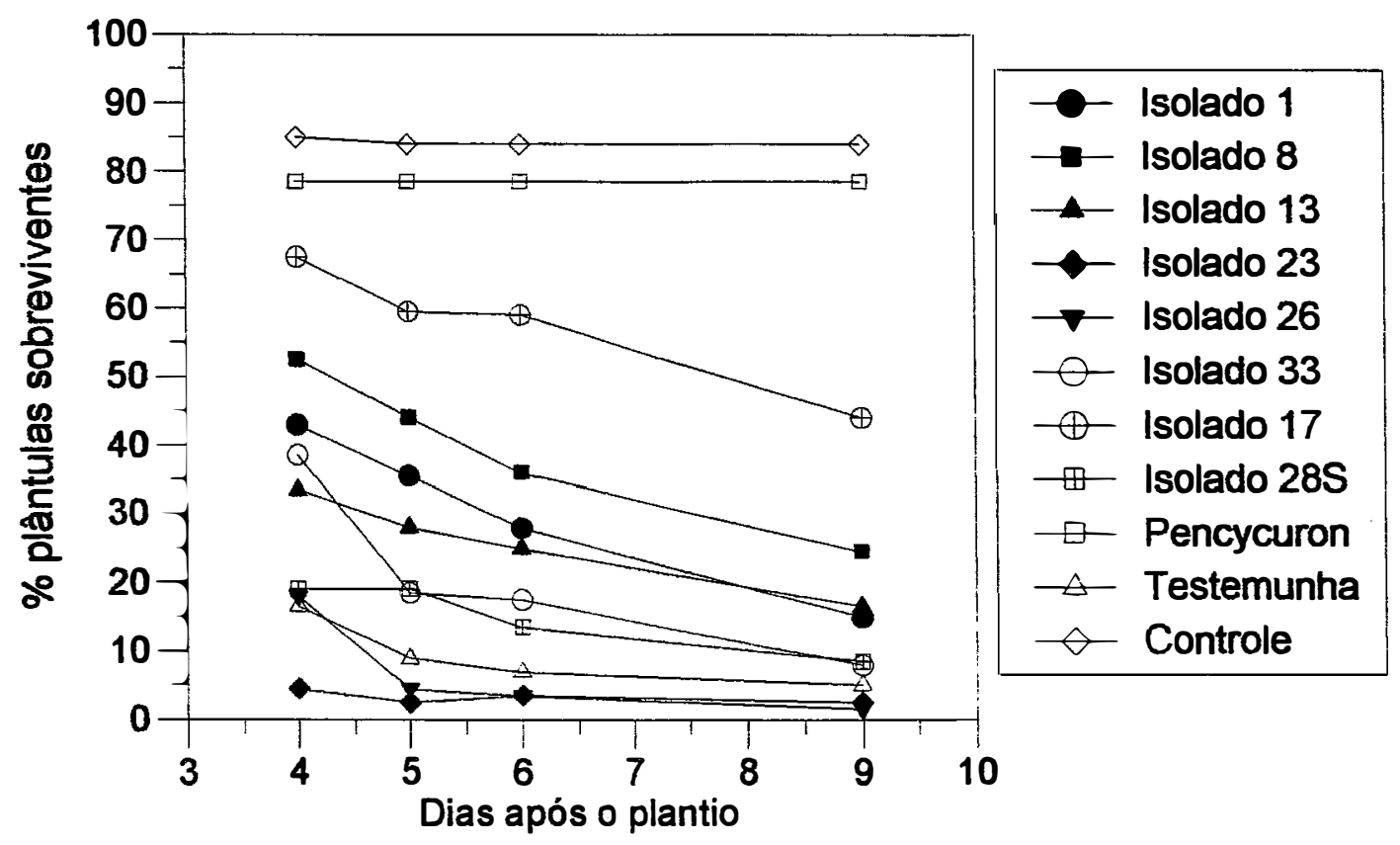

Figura 13. Efeito da adição de isolados de Trichoderma na dose de $10 \mathrm{~g}$ de sementes colonizadas/litro de solo, sobre a porcentagem de plântulas de rabanete sobreviventes ao tombamento de pré e pós emergência, 4 a 9 dias após 0 plantio, em experimento realizado em casa de vegetação. Campinas, SP., Abril - Maio, 1999.

Os isolados testados, com exceção do 8 , destacaram-se nos testes em laboratório como antagônicos a $R$. solani, mas não apresentaram o mesmo comportamento quando adicionados aos solos, à semelhança dos experimentos com $P$. aphanidermatum em pepino. Embora espécies de Trichoderma possam excretar B1-3-glucanases e quitinases, como foi observado para $T$. hamatum (Chet \& Baker, 1981) e T. harzianum (Hadar, et al.1979), a produção destas enzimas pode não estar relacionada à capacidade de antagonismo e de controle de $R$. solani no solo. ColeySmith et al. (1991), ao compararem isolados de $T$. viride e de $T$. harzianum para o controle de $R$. solani em alface, observaram que $o$ isolado mais eficiente apresentou pequena produção de enzimas extracelulares como ß-1-3-glucanase e quitinase e que 
isolados de $T$. harzianum, com elevada atividade enzimática, não apresentaram o mesmo comportamento no controle da doença.

Segundo Deacon \& Berry (1993) em geral o biocontrole é multifatorial, resultado da atuação de vários mecanismos simultaneamente, Ordentlich et al. (1991) apontam entre os mecanismos o reconhecimento especifico, produção de antibióticos e competição por nutrientes. Por esta razão Tronsmo (1996) argumenta que, embora a seleção de antagonistas in vitro possa facilitar a fase seguinte in vivo, na maioria dos experimentos não ocorre correlação entre os desempenho dos isolados em laboratório com os resultados dos testes in vivo.

Nestes experimentos foram obtidos dois isolados (26 e 33) com atividade antagônica a $P$. aphanidermatum em plântulas de pepino. Outro isolado (17) se destacou no controle de $R$. solani em plântulas de rabanete. Estes isolados, embora tenham proporcionado controle parcial do patógeno, têm potencial como antagonistas pois foram testados em solos naturais, sem tratamento para redução da sua população microbiana. Nestes experimentos foi favorecida a expressão da patogenicidade de $P$. aphanidermatum, pela adição da farinha de aveia, e trabalhou-se com elevado potencial de inóculo de $R$. solani.

4.2.4 Avaliação da integração da solarização com a incorporação de Trichoderma spp. e com o controle químico

Na Tabela 19 encontram-se as temperaturas obtidas às 15:00 horas a $10 \mathrm{~cm}$ de profundidade nos dois experimentos, 19 e 20, dentro e fora da casa de vegetação. Observa-se que as temperaturas médias atingidas pelas parcelas solarizadas foram superiores na área externa, sendo as máximas semelhantes entre os ambientes. 
Tabela 19. Temperaturas médias e máximas registradas nos solos às 15:00 horas na casa de vegetação e na área externa, a 10 e a $20 \mathrm{~cm}$ de profundidade, nos experimentos 19 e 20, realizados no período de 26/02 a 25/03/1999. Piracicaba, SP.

\begin{tabular}{llcccc}
\hline Horário & Ambiente & \multicolumn{3}{c}{ Temperaturas a $10 \mathrm{~cm}\left({ }^{\circ} \mathrm{C}\right)$} \\
\cline { 3 - 5 } & & \multicolumn{2}{c}{ Solarizado } & \multicolumn{2}{c}{ Não solarizado } \\
\cline { 3 - 5 } & & $\mathrm{T} \mathrm{Med}^{*}$ & $\mathrm{~T} \mathrm{Max}^{\star \star}$ & T Med & T Max \\
\hline \multirow{2}{*}{ 15:00 h } & Casa Vegetação & 41,5 & 49,3 & 35,3 & 40,5 \\
& Área externa & 44,5 & 49,3 & 33,0 & 38,1 \\
\hline
\end{tabular}

* Temperatura média registrada a $10 \mathrm{~cm}$ de profundidade.

** Temperatura máxima registrada a $10 \mathrm{~cm}$ de profundidade.

Na Tabela 20 encontram-se os resultados médios do controle de $P$. aphanidermatum, avaliado pela porcentagem de plântulas sobreviventes ao tombamento de pós-emergência, promovido pelos fatores solarização e tratamentos, bem como a significância destes fatores e interações. Dentro da casa de vegetação não houve efeito da cobertura plástica sobre o controle de Pythium aphanidermatum. Os tratamentos diferiram entre si, sendo o controle obtido apenas com o tratamento químico, com metalaxyl + mancozeb. Não houve interação entre os tratamentos.

$\mathrm{Na}$ área externa a emergência do tratamento não solarizado foi significativamente maior, mas houve interação entre os tratamentos e a solarização. Apenas o tratamento químico promoveu o controle do patógeno em ambas as coberturas, solarizada e não solarizada, com igual eficiência. Verifica-se na Figura 14 que a interação ocorreu porque o tratamento biológico aumentou a incidência de tombamento no solo solarizado. Nos demais tratamentos a incidência de tombamento foi semelhante para ambas as coberturas (Figura 14). Koch (1999) observou grande variabilidade ao empregar produtos biológicos comerciais para o controle de Pythium ultimum em substrato padronizado. Ao aquecer o substrato, a $60^{\circ} \mathrm{C}$ por 24 horas, este autor verificou maior pressão de infeção, maior variabilidade dos resultados e menor efeito do controle biológico quando comparados ao substrato não aquecido. $O$ mesmo pode ter ocomido neste experimento. $O$ patógeno, inclusive, pode ter sido favorecido pelos grãos de trigo utilizados para adicionar o antagonista ao solo. Como no 
experimento efetuado na casa de vegetação, Minuto et al. (1995) obtiveram aumento na incidência de $P$. ultimum em pepino após a adição de Trichoderma ao solo, o qual não ocorreu em solo solarizado. Estes autores obtiveram controle de $P$. ultimum apenas pela aplicação da solarização. A associação da solarização com controle biológico resultou em aumento significativo do controle em apenas um de 3 experimentos.

Os resultados dos dois experimentos mostraram que apenas o controle químico, mesmo tendo sido empregada metade da dose recomendada, foi eficiente, não ocorrendo tombamento neste tratamento, independentemente da procedência das amostras, tanto das parcelas solarizadas quanto das não solarizadas. $A$ associação entre o controle químico e a solarização também não foi mais eficiente que apenas 0 controle químico.

Também para Rhizoctonia solani os experimentos 19 e 20 efetuados, respectivamente, dentro e fora da casa de vegetação, foram analisadas separadamente (Figura 15). Dentro da casa de vegetação houve diferença entre as coberturas, indicando que a solarização promoveu o controle do patógeno. Não houve diferença entre os tratamentos e não ocorreu interação entre solarização e tratamentos.

$\mathrm{Na}$ área externa houve diferença significativa entre as coberturas plásticas, entre os tratamentos e interação entre solarização e tratamentos (Tabela 21). Observase que sob cobertura plástica nenhum tratamento teve efeito porque o patógeno já havia sido controlado pela solarização, não sendo necessário tratamento adicional. Sem cobertura plástica o controle químico foi mais eficiente, semelhante aos tratamentos solarizados. Nestes experimentos, como a solarização proporcionou controle eficiente do patógeno, não houve vantagem na associação de técnicas de controle. 
Tabela 20. Fatores, tratamentos e médias de viabilidade de Pythium aphanidermatum, avaliada pela porcentagem de plântulas de pepino sobreviventes ao tombamento de pós-emergência, em dois experimentos em uma casa de vegetação e em uma área externa, após solarização, efetuada durante o período de 26 de fevereiro a 25 de março de 1999 e integração da solarização com tratamentos químico e biológico.

\begin{tabular}{|c|c|c|c|c|}
\hline Locais & Fatores & Tratamentos & Médias & Prob $<F$ \\
\hline Casa de vegetação & Solarização & S. solarizado & 65,2 & 0,4429 \\
\hline \multirow[t]{5}{*}{$(C V=58,4 \%)$} & & S. não solarizado & 58,8 & \\
\hline & Tratamentos & S/ tratamento & 47,4 & $0,0003^{1}$ \\
\hline & & Trichoderma (Isolado 26) & 38,6 & \\
\hline & & Pencycuron & 100,0 & \\
\hline & $\begin{array}{l}\text { Solarização } \\
\text { tratamentos }\end{array}$ & $x$ & & 0,1083 \\
\hline Área externa & Solarização & S. solarizado & 58,9 & $0,0393^{1}$ \\
\hline \multirow[t]{5}{*}{$(C V=31,8 \%)$} & & S.não solarizado & 67,9 & \\
\hline & Tratamentos & S/ tratamento & 48,5 & $0,0001^{1}$ \\
\hline & & Trichoderma (Isolado 26) & 41,7 & \\
\hline & & Pencycuron & 100,0 & \\
\hline & $\begin{array}{l}\text { Solarização } \\
\text { tratamentos }\end{array}$ & $x$ & - & $0,0342^{1}$ \\
\hline
\end{tabular}




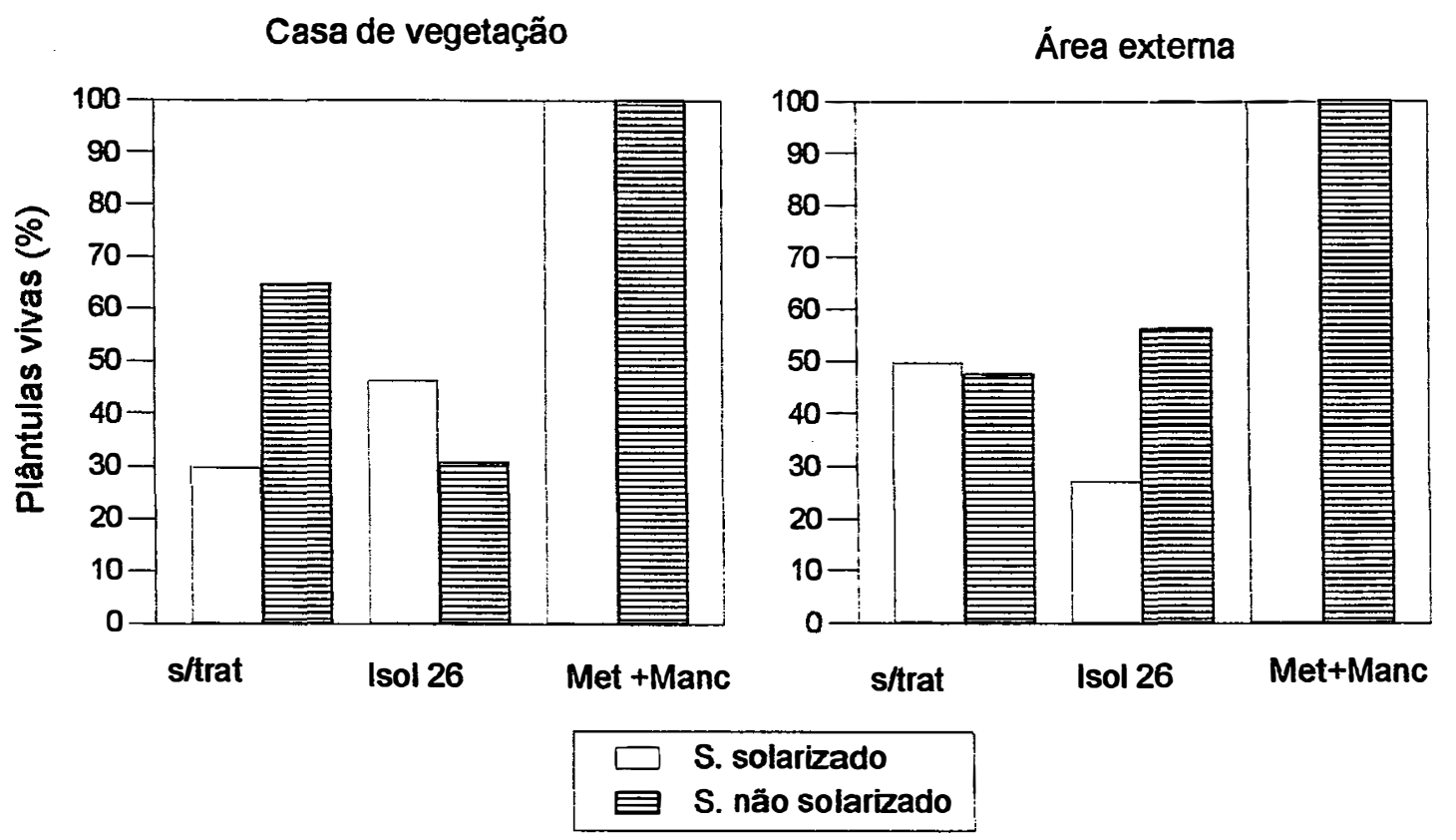

Figura 14. Plântulas de pepino sobreviventes ao tombamento de pós-emergência provocado por Pythium aphanidermatum, em dois experimentos realizados na casa de vegetação e na área externa, após solarização, efetuada no período de 26 de fevereiro a 25 de março de 1999 seguida de incorporação ao solo do isolado 26 de Trichoderma ou aplicação de metalaxyl + mancozeb. Campinas, SP - Maio, 1999.

Embora a estratégia da integração da solarização com a introdução de agentes de biocontrole seja preconizada, neste trabalho não foram observados efeitos sinergísticos desta associação. Para Pythium aphanidermatum, a integração da solarização com a incorporação de Trichoderma não proporcionou controle do patógeno, ampliando a incidência de tombamento no tratamento solarizado na área extema. Para $R$. solani apenas a solarização foi suficiente para inativar o patógeno, não tendo a incorporação de Trichoderma trazido benefícios adicionais. Resultados semelhantes foram obtidos por Minuto et al. (1995), que observaram que apenas a solarização foi eficiente para o controle deste patógeno em feijoeiro. Também em 
experimentos dentro de casas de vegetação a solarização foi tão eficiente que a incorporação de Trichoderma, após a solarização, não resultou em aumento no controle de R. solani (Garibaldi \& Tamieti, 1989). Por outro lado, foram obtidas vantagens na incorporação de Trichoderma após a solarização para o controle de $R$. solani em bulbos de íris (Chet et al., 1982), em tubérculos de batata (Davis, 1991), e para o controle de Sclerotium cepivorum (Pereira et al., 1996).

Tabela 21. Fatores, tratamentos e médias de viabilidade de Rhizoctonia solani, em dois experimentos, em casa de vegetação e em área externa, após solarização, efetuada durante o período de 26 de fevereiro a 25 de março de 1999, e integração da solarização com tratamentos químico e biológico.

\begin{tabular}{|c|c|c|c|c|}
\hline Locais & Fatores & Tratamentos & Médias & Prob $<F$ \\
\hline Casa de vegetação & Solarização & S. solarizado & 86,9 & $0,0101^{1}$ \\
\hline \multirow[t]{5}{*}{$(\mathrm{CV}=6,4 \%)$} & & S.não solarizado & 78,0 & \\
\hline & Tratamentos & $\mathrm{S} /$ tratamento & 79,4 & 0,1639 \\
\hline & & Trichoderma (Isolado 17) & 83,6 & \\
\hline & & Pencycuron & 84,4 & \\
\hline & $\begin{array}{l}\text { Solarização } \\
\text { tratamentos }\end{array}$ & $x$ & - & 0,0827 \\
\hline Área externa & Solarização & S. solarizado & 90,0 & $0,0025^{1}$ \\
\hline \multirow[t]{5}{*}{$(\mathrm{CV}=6,3 \%)$} & & S. não solarizado & 68,0 & \\
\hline & Tratamentos & $\mathrm{S} /$ tratamento & 74,9 & $0,0024^{1}$ \\
\hline & & Trichoderma (Isolado 17) & 77,1 & \\
\hline & & Pencycuron & 85,6 & \\
\hline & $\begin{array}{l}\text { Solarização } \\
\text { tratamentos }\end{array}$ & $x$ & - & $0,0012^{1}$ \\
\hline
\end{tabular}

\footnotetext{
Probabilidade de F $>0,05$ considerada significativa.
} 


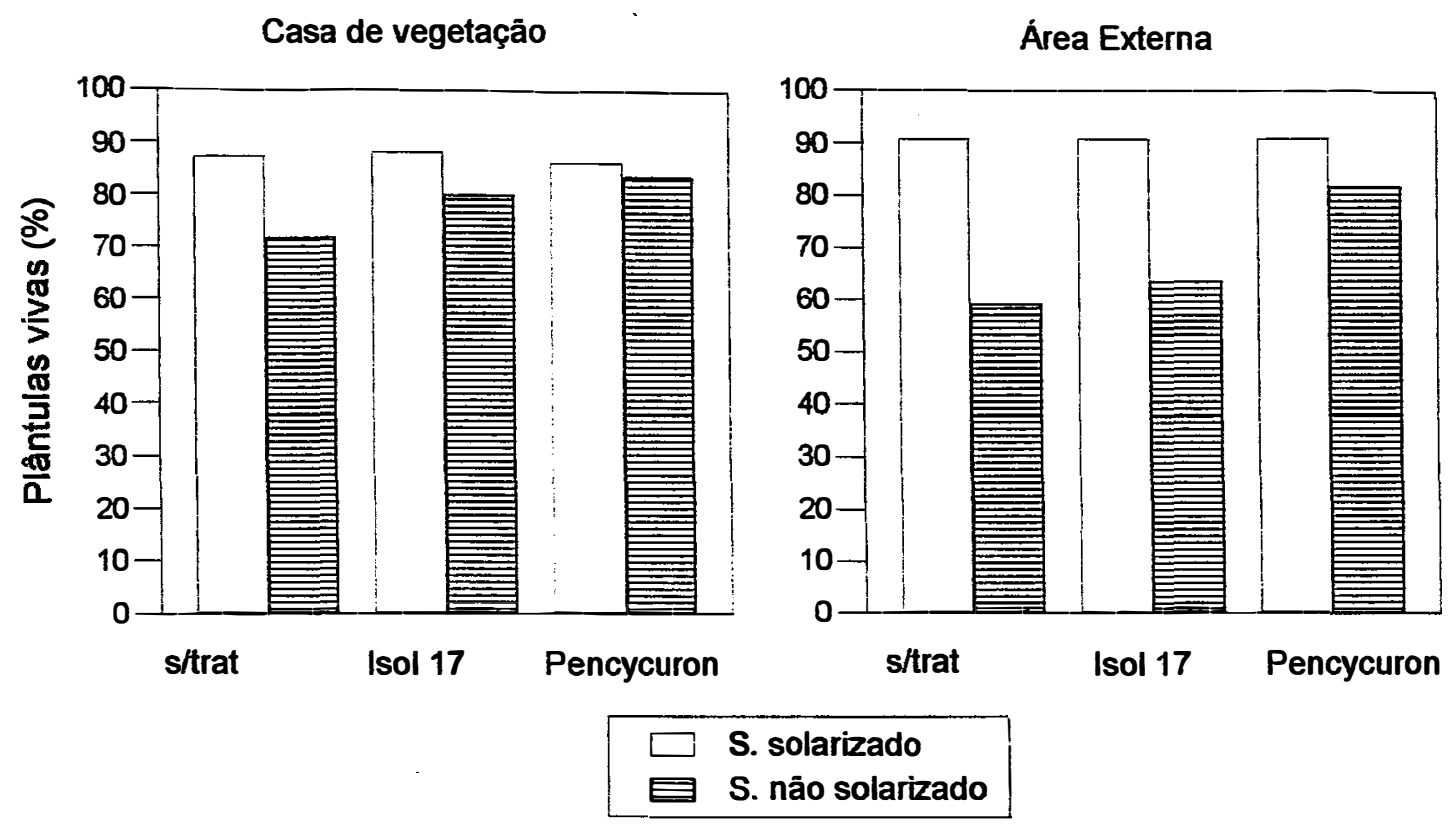

Figura 15. Plântulas de rabanete sobreviventes ao tombamento de pré e pósemergência provocado por Rhizoctonia solani, em dois experimentos realizados em casa de vegetação e em área externa, após solarização, efetuada durante o período de 26 de fevereiro a 25 de março de 1999, e posterior incorporação do isolado 17 de Trichoderma sp. ou após o tratamento com pencycuron. Campinas, SP. - Abril - Maio, 1999. 


\section{CONCLUSÕES}

A solarização em casas de vegetação no verão atinge temperaturas no solo letais ao patógeno Rhizoctonia solani.

As temperaturas médias e máximas às 15:00 horas foram semelhantes dentro e fora da casa de vegetação. Entretanto, às 8:00 horas, as temperaturas foram maiores no interior da casa de vegetação, indicando menor perda de calor durante a noite. Como conseqüência o período de tratamento para o controle de Rhizoctonia solani foi um pouco mais curto na casa de vegetação - 20 a 30 dias, quando comparado ao período necessário na área externa - 40 a 45 dias.

Como as temperaturas atingidas pelos solos nos tratamentos solarizados às 15:00 horas foram semelhantes dentro e fora de casas de vegetação, tendo o mesmo ocorrido no outono, estima-se que, assim como em áreas descobertas, o verão é a época mais adequada para solarização em casas de vegetação.

Em função das variações de temperaturas ocorrentes nos solos solarizados, como conseqüência das variações climáticas e dos tratamentos, Rhizoctonia solani perdeu a viabilidade de forma proporcional à temperatura atingida pelo solo. $\mathrm{Na}$ maioria dos experimentos as temperaturas foram insuficientes para proporcionar 0 controle de Pythium aphanidermatum.

Com o emprego dos isolados de Trichoderma spp., selecionados por apresentarem maior parasitismo/antibiose, foi obtido controle significativo de Pythium aphanidermatume Rhizoctonia solani em experimentos in vivo, com resultados, porém, inferiores aos dos tratamentos químicos.

Não houve efeito da integração da solarização com controle biológico ou químico. Para Pythium aphanidermatum, a incorporação ao solo solarizado do antagonista não resultou em redução na viabilidade do patógeno e o controle químico foi muito eficiente em ambos os solos, solarizado e não solarizado. Para Rhizoctonia 
solani a solarização foi tão eficiente que os demais tratamentos, biológico e químico, não trouxeram benefício adicional. 


\section{REFERÊNCIAS BIBLIOGRÁFICAS}

BELL, D.K; WELLS, H.D.; MARKHAM, C.R. In vitro antagonism of Trichoderma species against six fungal pathogens. Phytopathology, v.72, n.4, p.379-382, 1982.

BEN-YEFET, Y; STAPLETON, J.J.; WAKEMAN, R.J.; DeVAY, J.E. Comparative effects of soil solarization with single and double layers of polyethilene film on survival of Fusarium oxysporum f.sp. vasinfectum. Phytoparasitica, v.15, n.3, p.181-185, 1987.

BETTIOL, W.; GHINI, R.; GALVÃO, J.A.H. Solarização do solo para o controle de Pythium e plantas daninhas em cultura de crisântemo. Scientia Agricola, v.51, n.3, p.459-462, 1994.

BOLLEN, G.J. Lethal temperatures of soil fungi. In: PARKER, C.A.; ROVIRA, A.D.; MOORE, K.J.; WONG, P.T.W. (Eds.) Ecology and management of soilborne plant pathogens, Proceedings of the Fourth International Congress of Plant Pathology, St. Paul:The American Phytopathological Society, 1985. cap.5, p.191193.

BOURBOS, V.A.; SKOUDRIAKIS, M.T. Soil solarization for the control of Verticillium wilt of greenhouse tomato. Phytoparasitica, v. 24, n.4, p.277-280, 1996.

CARTIA, G.; CIPRIANO, T. Effect of solarization and fumigants on soil bome pathogens of pepper in greenhouse. Acta Horticulturae, v. 255, p.111-115, 1989.

CEBOLLA, V.; MARTINEZ, P.F.; DEL BUSTO, A.; GÒMEZ DE BARREDA, D.; TUSET, J.J. Dosage reduction of methyl bromide fumigation in the Spanish mediterranean coast. Acta Horticulturae, v. 382, p.156-163, 1995. 
CHET, I. Trichoderma - application, mode of action, and potential as a biocontrol agent of soilbome plant pathogenic fungi. In: CHET, I. (Ed.) Innovative approaches to plant disease control. New York: John Wiley \& Sons, 1987. Cap.6, p.137-160.

CHET, I.; 巴AKER, R. Isolation and biocontrol potential of Trichoderma hamatum from soil naturally suppressive to Rhizoctonia solani. Phytopathology, v. 71:286-290, 1981.

CHET, I.; ELAD, Y.; KALFON, A.; HADAR, Y.; KATAN, J. Integrated control of soilbome and bulbbome pathogens in iris. Phytoparasitica, v. 10, n. 4, p.229-236, 1982.

COLE, J.S. \& ZVENYKA, Z. Integrated control of Rhizoctonia solani and Fusanium solani in tobacco transplants with Trichoderma harzianum and triadimenol. Plant Pathology, v. 37, p.271-277, 1988.

COLEY-SMITH, J.R.; RIDOUT, C.J.; MITCHELL, C.M.; LYNCH, J.M. Control of bottom rot disease of lettuce (Rhizoctonia solani) using preparations of Trichoderma viride, T. harzianum or tolclofos-methyl. Plant Pathology, v. 40, p.359-366, 1991.

DAVIS, J.R. Soil solarization; pathogen and disease control and increases in crop yield and quality: short-and-long-term effects and integrated control. In: KATAN, J.; DeVAY, J.E. Soil solarization. Boca Raton: CRC Press, 1991. cap.3, p.39-50.

DEACON, J.W.; BERRY, L.A. Biocontrol of soil-borne plant pathogens: concepts and their application. Pesticide Science, v. 37, p.417-426, 1993.

DENNIS, C.; WEBSTER, J. Antagonistic properties of species-groups of Trichoderma . I. Production of non-volatile antibiotics. Trasactions of the British Mycologycal Society, v. 57, n.1, p.25-39, 1971.

DUFF, J.D. \& CONNELLY, M.I. Effect of solarization using single and double layers of clear plastic mulch on Pythium, Phytophtora and Sclerotium species in a nursery potting mix. Australasian Plant Pathology, v.22, n.1, p.28-35, 1993. 
ELAD, Y.; CHET, I.; BOYLE, P.; HENIS, Y. Parasitism of Trichoderma spp. on Rhizoctonia solani and Sclerotium rolfsii - scaning electron microscopy and fluorescence microscopy. Phytopathology, v.73, n.1, p.85-88, 1983.

ELAD, Y.; CHET, I.; HENIS, Y. Biological control of Rhizoctonia solani in strawberry fields by Trichoderma harzianum. Plant and Soil, v. 60, p.245-254, 1981.

ELMER, W.E.; ELLIOT, G. The effect of biological products on supression on Rhizoctonia root rot of poinsettias, 1997. Biological and Cultural Tests, v.14, p.67, 1998.

FLETCHER, J.T. Diseases of greenhouse plants. Essex:Longman Group Limited, 1984. $335 \mathrm{p}$.

FRAVEL, D.R. Role of antibiosis in the biocontrol of plant diseases. Annual Review of Plant Pathology, v.26, p.75-91, 1988.

GAML.IEL, A.; HADAR, E.; KATAN, J. Soil solarization to improve yield of gypsophila in monoculture systems. Acta Horticulturae, v. 255, p.131-138, 1989.

GARIBALDI, A.; GULINO, M.L. Soil solarization in southern European countries, with emphasis on soilborne disease control of protected crops. In: KATAN, J.; DeVAY, J.E. Soil solarization. Boca Raton: CRC Press, 1991. cap.16, p.227-235.

GARIBALDI, A.; TAMIETTI, G. Solar heating: recent results obtained in northern Italy. Acta Horticulturae, v. 255, p.125-129, 1989.

GHINI, R. A solar collector for soil disinfestation. Netherlands Journal of Plant Pathology, v.99, p.45-50, 1993.

GHINI, R.; BETTIOL, W. Coletor solar para desinfestação de substratos. Summa Phytopathologica, v.17, n.3,4, p.281-286, 1991.

GHINI, R.; BETTIOL, W.; ARMOND, G. Desinfestação de substratos com a utilização de coletor solar. Bragantia, v.51, n.1, p.85-93, 1992. 
GHINI, R.; KIMATI, H. Método de iscas para obtenção de isolados de Trichoderma antagônicos a Botrytis cinerea. Jaguariúna: EMBRAPA - CNPDA, 1989. 13p. (Boletim de Pesquisa № 3, Janeiro).

GHINI, R.; PARAÍBA, L.C.; LIMA, M.W.P. Determinação de período para solarização do solo na região de Campinas, SP. Summa Phytopathologica, v.20, n.2, p.131-133, 1994.

GRIFFIN, G.J.; BAKER, R. Population dinamics of plant pathogens and associated organisms in soil in relation to infectious inoculum. In: KATAN, J.; DeVAY, J.E. Soil solarization. Boca Raton: CRC Press, Inc., 1991. cap.1, p.4-21.

GULINO, M.L.; MINUTO, A.; GARIBALDI, A. Improved method of bench solarization for the control of soilborne diseases in basil. Crop Protection, v.17, n.6, p.497-501, 1998.

HADAR, Y.; CHET, I.; HENIS, Y. Biological control of Rhizoctonia solani damping-off with wheat bran culture of Trichoderma harzianum. Phytopathology, v.69, p.64-68, 1979.

HARMAN, G.E.; CHET, I.; BAKER, R. Trichoderma hamatum effects on seed and seedling disease induced in radish and pea by Pythium spp. or Rhizoctonia solani. . Phytopathology, v.70, n.12, p.1167-1172, 1980.

HARMAN, G.E.; TAYLOR, A.G.; STASZ, T.E. Combining effective strains of Trichoderma harzianum and solid matrix priming to improve biological seed treatments. Plant Disease, v.73, p.31-637, 1989.

HENIS, Y.; GHAFFAR, A.; BAKER, R. Integrated control of Rhizoctonia solani damping-off of radish : effect of successive plantings, PCNB, and Trichoderma harzianum on pathogen and disease. Phytopathology, v.68, n.6, p.900-907, 1978.

JACKICSH-MATSUURA, A.B.; MENEZES, M. Efeito de Trichoderma spp. no controle de Pythium aphanidermatum em fumo (Nicotiana tabacum). Summa Phytopathologica, v.25, p. 161-164, 1999. 
KAEWRUANG, W.; SIVASITHAMPARM K.; HARDY, G.E. Effect of solarization of soil within plastic bags on root rot of gerbera (Gerbera jamesonii L.). Plant and Soil, v.120, p.303-306, 1989.

KATAN, J. Soil solarization: integrated control aspects. In: Hall, R. (Ed.) Principles and Practices of Managing Soilborne Plant Pathogens, St. Paul: APS Press, The American Phytopathological Society, 1996, cap.12, p. 213-236.

KATAN, J.; DeVAY, J.E. Soil solarization; historical perspectives, principles and uses. In: KATAN, J.; DeVAY, J.E. Soil solarization. Boca Raton: CRC Press, 1991. cap.2, p.24-37.

$\mathrm{KOCH}, \mathrm{E}$. Evaluation of commercial products for microbial control of soil-bome plant diseases. Crop Protection, v.18, p.119-125, 1999.

LATORRE, B.A. Cucurbitaceae, enfermedades. In: LATORRE, B; VAUGHAN, M.A. \& AGUILAR, P.G. Plagas de las hortalizas - Manual de manejo integrado. Santiago: FAO, 1990. cap.4, p.155-180.

LE BIHAN, B.; SOULAS, M.L; CAMPOROTA, P.; SALERNO, M.I.; PERRIN, R. Evaluation of soil solar heating for control of damping-off fungi in two forest nurseries in France. Biology and Fertility of Soils, v. 25, p.189-195, 1997.

LEFĖFRE, A.F.V.; SOUZA, N.L. Determinação da temperatura letal para Rhizoctonia solani e Sclerotium rolfsii e efeito da solarização sobre a temperatura do solo. Summa Phytopathologica, v.19, n.2, p.107-112, 1993.

LEWIS, J.A.; PAPAVIZAS, G.C. A new approach to stimulate population proliferation of Trichoderma species and other potential biocontrol fungi induced into natural soils. Phytopathology, St. Paul, v. 74, p.1240-1244, 1984.

LEWIS, J.A. \& PAPAVIZAS, G.C. Biocontrol of plant diseases: the approach for tomorrow. Crop Protection, v. 10, p.95-105, 1991. 
LEWIS, J.A.; BARKSDALE, T.H.; PAPAVIZAS, G.C. Greenhouse and field studies on the biological control of tomato fruit rot caused by Rhizoctonia solani. Crop Protection, v.9, p.8-14, 1990.

LIFSHITZ, R.; WINDHAM, M.T.; BAKER, R. Mechanism of biological control of preemergence damping-off of pea by seed treatment with Trichoderma spp. Phytopathology, v.76, p.720-725, 1986.

LITTEL, R.C.; FREUND, R.J.; SPECTOR, P.C. SAS System for linear models, $3^{\text {a }}$ Ed., Cary. SAS Institute, Inc., 1991, 329 p.

LOURD, M.; ALVES, M.L.B; BOUHOT, D. Análise qualitativa e quantitativa de espécies de Pythium patogênicas dos solos no município de Manaus. I. Solos de terra firme. Fitopatologia Brasileira, v.11, n.9, p.479-485, 1986.

LOURD, M.; ALVES, M.L.B; BOUHOT, D. Análise qualitativa e quantitativa de espécies de Pythium patogênicas nos solos da região de Manaus. II. Solos da várzea. Fitopatologia Brasileira, v.12, n.3, p.215-218, 1987.

XMAHRER, Y. Physical principles of solar heating of soils by plastic mulching in the field and in glasshouses and simulation models. In: KATAN, J.; DeVAY, J.E. Soil solarization. Boca Raton: CRC Press, 1991. cap.6, p.76-86.

MANSOORI, B.; JALIANI, N.K.H.; Control of soilborne pathogens of watermelon by solar heating. Crop Protection, v.15, n.15, p.423-424, 1996.

MAY, L.L. Controle biológico, físico e químico de Phytophtora parasitica Dastur em mudas de citros. Piracicaba, 1994. 89 p. Dissertação (Mestrado) - Escola Superior de Agricultura Luiz de Queiroz, Universidade de São Paulo.

MELO, I.S. Trichoderma e Gliocladium como bioprotetores de plantas. Revisão Anual de Patologia de Plantas, v. 4., p.261-295, 1996.

X MENZIES, J.G.; EHRET, D.L.; STAN, S. Effect of inoculum density of Pythium aphanidermatum on the growth and yield of cucumber plants grown in recirculating nutrient film culture. Canadian Journal of Plant Pathology, v. 18, p. 50-54, 1996. 
MESSIAEN, C.M.; BLANCARD, D.; ROUXEL, F; LAFON, R. Enfermedades de las cucurbitaceas. In:Enfermedades de las hortalizas. Madrid: Ediciones Mundiprensa, 1995. Cap. 4, p.227-273.

MIHUTA-GRIMM; ROWE, R.C. Trichoderma spp. as biocontrol agents of Rhizoctonia damping-off of radish in organic soil and comparison of four delivery systems. Phytopathology, v. 76, p.306-312, 1986.

MINUTO, A.; MIGHELI, Q.; GARIBALDI, A. Integrated control of soil-bome plant pathogens by solar heating and antagonistic microrganisms. Acta Horticulturae, v.382, p.139-143, 1995.

MORTON, H.V. Chemical management. In: CAMPBELL, C.L.; BENSON, D.M. (Eds.) Epidemiology and management of root diseases. Berlin:Springer-Verlag, 1994. cap.9, p.276-292.

NORONHA, M.A.; SOBRINHO, S.A.; SILVEIRA, N.S.S.; MICHEREFF, S.; MARIANO, R.L.R.; MARANHÃO, E. Seleção de isolados de Trichoderma spp. para o controle de Rhizoctonia solani em feijoeiro. Summa Phytopathologica, v.22, n.2, p.156$162,1996$.

ORDENTLICH, A.; MIGHELI, Q.; CHET, I. Biological control activity of three Trichoderma isolates against fusarium wilts of cotton and muskmelon and lack of correlation with their lyctic enzymes. Journal of Phytopathology, v.133, p,177-186, 1991.

ORLIKOWSKI, L.B.; WODJDYLA, A.T. Application of Binab-T to reduce chrysanthemum foot rot caused by Rhizoctonia solani, 1986. Biological and Cultural Tests, v.12, p.41, 1996.

PAPAVIZAS, G.C. Trichodema and Gliocladium: biology, ecology and potential for biocontrol. Annual Review of Phytopathology, v. 23, p.23-25, 1985. 
PEREIRA, J.C.R.; CHAVES, G.M.; ZAMBOLIM, L.; MATSUOKA, K.; ACUÑA, R.S.; VALE, F.X.R. do. Controle de Sclerotium cepivorum Berk. pelo uso combinado de vermicomposto, solarização, Trichoderma harzianum e Bacillus subtilis. Summa Phytopathologica, v.22, p. 228-234, 1996.

PULLMAN, G.S.; DeVAY, J.E.; GARBER, R.H.; WEINHOLD, A.R. Soil solarization: effects on verticillium wilt of cotton and soilbome populations of Verticillium dahliae, Pythium spp., Rhizoctonia solani and Thielaviopsis basicola. Phytopathology, v.71, n.9, p.954-959, 1981.

RANKING, L.; PAULITZ, T.C. Evaluation of rhizosphere bacteria for biological control of Pythium root rot of greenhouse cucumbers in hydroponic culture. Plant Disease, $v$. 78, p.447-451, 1994.

RAYMUNDO, S.A.; ALCAZAR, J. Increasing efficiency of soil solarization in controlling root-knot nematodes by using two layers of plastic mulch. Journal of Nemathology, v.18, n.4, p.638, 1986. /Resumo.

RISTAINO, J.B.; PERRY, K.B.; LUMSDEM, R.D. Effect of solarization and Gliocladium virens on sclerotia of Sclerotium rolfsii, soil microbiota, and the incidence of southem blight of tomato. Phytopathology, v.81, p.1117-1124, 1991.

RISTAINO, J.B.; THOMAS, W. Agriculture, methyl bromide, and the ozone hole. Can we fill the gaps? Plant Disease, v.81, n.9, p. 964-977, 1997.

SILVA, S.; CERESINI, P.C.; SOUZA, N.L.; AGUIAR, L.F. Sensibilidade térmica $x$ micelial e esclerodial de isolados de Rhizoctonia solani GA $4 \mathrm{HGI}$. Summa Phytopathologica, v.22, n.3/4, p.252-256, 1996.

SIVAN, A.; ELAD, Y; CHET, I. Biological control effects of a new isolate of Trichoderma harzianum on Pythium aphanidermatum. Phytopathology, v.74, n.4, p.498-501, 1984.

SNEH, B.; KATAN, J.; HENIS, Y; WAHL, I. Methods for evaluating inoculum density of Rhizoctonia in naturally infested soil. Phytopathology, v.56, n.1, p.74-78, 1966. 
SOUZA, N.L. Solarização do solo. Summa Phytopathologica, v.20, n.1, p.3-15, 1994.

STAPLETON, J.J.; DE VAY, J.E. Soil solarization: a natural mechanism of integrated pest management. In: REUVENI, R. (Ed.) Novel aproaches to integrated pest management. Boca Raton:CRC Press, 1995. cap.15, p.309-350.

STEVENS, C.; KHAN, V.A.; BROWN, J.E.; HOCHMUTH, G.J.; SPLITTSTOESSER, W.E.; GRANBERRY, D.M. Plastic chemistry and technology as related to plasticulture and solar heating of soil. In: KATAN, J.; DeVAY, J.E. Soil solarization. Boca Raton: CRC Press, 1991. cap.10, p.141-158.

THRANE, C.; TRONSMO, A.; JENSEN, D.F. Endo-1-3-ß-glucanase and celulase from Trichoderma harzianum: purification and partial characterization, induction of biological activity against plant pathogenic Pythium spp. European Journal of Plant Pathology, v.103, p.331-344, 1997.

TJAMOS, E.C.; KARAPAPA, V.; BARDAS, D. Low cost application of soil solarization in covered plastic houses for the control of Verticillium wilt in tomatoes in Greece. Acta Horticulturae, v. 255, p.139-149, 1989.

TOMSON, T.B.; ATHOW, K.L.; LAVIOLETTE, F.A. The effect of temperature on the pathogenicity of Pythium aphanidermatum, $P$. debaryanum and $P$. ultimum on soybean. Phytopathology, v.61, p.933-935, 1971.

TRONSMO, A. Trichoderma harzianum in biological control of fungal diseases. In: Hall, R. (Ed.) Principles and Practices of Managing Soilborne Plant Pathogens, APS Press, The American Phytopathological Society, St. Paul, Minnesota, p. 213-236, 1996.

WALTER, J.F.; BRUETTE, T. A comparison of two microbial biocontrol agents to control zinnia damping-off. Biological and Cultural Tests, v.12, p.74, 1996.

WATERHOUSE, E.M.; WATERSON, J.M. Pythium aphanidermatum. C.M.I. Descriptions of Pathogenic Fungi and Bacteria, No 36, 1964. 2p. 
WOLFHECKEL, H.; FUNCK JENSEN, D. Use of Trichodema harzianum and Gliocloadium virens for the biological control of post-emergence damping-off and root rot of cucumbers caused by Pythium ultimum. Journal of Phytopathology, $v$. 136, p.221-230, 1992. 